Universidad de Chile

Facultad de Ciencias Sociales

Carrera de Sociología

\title{
DENUNCIAR LO INJUSTO: LA CRÍTICA SOCIAL DE LAS CLASES MEDIAS Y SU RELACIÓN CON EL CAMBIO Y LA REPRODUCCIÓN SOCIAL
}

\author{
MEMORIA PARA OPTAR AL TÍTULO DE SOCIÓLOGO
}

Profesora guía: Emmanuelle Barozet

Estudiante: Cristóbal Moya 
"El fundamento de toda crítica irreligiosa es que el hombre hace la religión, y no la religión al hombre. Y la religión es la autoconciencia y el autosentimiento del hombre que aún no se ha encontrado a sí mismo o ha vuelto a perderse. Pero el hombre no es un ser abstracto, agazapado fuera del mundo. El hombre es el mundo de los hombres, el Estado, la sociedad. Este Estado, esta sociedad, producen la religión, una conciencia del mundo invertida, porque ellos son un mundo invertido [...] La lucha contra la religión es, por tanto, indirectamente, la lucha contra aquel mundo que tiene en la religión su arma espiritual [...] La misión de la historia consiste, según esto, en descubrir la verdad más acá, una vez que se ha hecho desaparecer al más allá de la verdad. Y, ante todo, la misión de la filosofía, puesta al servicio de la historia, después de desenmascarar la forma de santidad de la autoenajenación del hombre, está en desenmascarar la autoenajenación bajo sus formas profanas. La crítica del cielo se trueca, de este modo, en la crítica de la tierra, la crítica de la religión en la crítica del derecho, la crítica de la teología en la crítica de la política"

Karl Marx (1982, pp. 491-492)

"Los juegos sociales son, en todo caso, muy difíciles de describir en su doble verdad. En efecto, a los implicados no les interesa demasiado la objetivación del juego, y quienes no lo están a menudo se encuentran mal situados para experimentar y sentir aquello que sólo se aprende y comprende si se participa en él, de modo que sus descripciones, en las que la evocación de la experiencia maravillada del creyente brilla por su ausencia, tienen muchas posibilidades de pecar, en opinión de los participantes, de triviales y sacrílegas a la vez. El «listillo», ensimismado en el placer de desmitificar y denunciar, ignora que aquellos a los que cree desengañar, o desenmascarar, conocen y rechazan a la vez la verdad que pretende revelarles. No puede comprender, y tenerlos en cuenta, los juegos de self deception, que permiten perpetuar la ilusión sobre uno mismo y salvaguardar una forma tolerable, o soportable, de «verdad subjetiva» frente a los llamamientos a las realidades y al realismo, a menudo con la complicidad de alguna institución"

Pierre Bourdieu (1999, p. 249) 


\section{Agradecimientos}

El trabajo empírico y reflexivo que se presenta a continuación no hubiera sido posible sin el apoyo de los proyectos Fondecyt regular 1130276 "Justicia social y tolerancia a la desigualdad: análisis subjetivo de la diferenciación social en un régimen neoliberal maduro", a cargo de la Dra. Emmanuelle Barozet y Fondecyt regular 1130800 "Juicios sobre las clases medias: para una sociología de la crítica en Chile”, a cargo del Dr. Mac-Clure y con la Dra. Barozet como co-investigadora. Ambos académicos han sido los principales interlocutores de este trabajo y generosamente han abierto sus investigaciones a la colaboración.

Asimismo, fue fundamental la beca del Centro de Estudios del Conflicto y la Cohesión Social (COES) CONICYT/FONDAP/15130009 para finalizar este trabajo. Las escasas ayudas disponibles para tesistas hacen aún más valorable el esfuerzo de este centro por contribuir a las ciencias sociales en Chile.

Ya que ningún trabajo intelectual es un producto individual, van también mis agradecimientos a los profesores, compañeros y colegas que acompañaron este proceso. Especialmente, me gustaría reconocer el rol de docentes como Omar Aguilar, Claudio Duarte y Carlos Ruiz en tanto activos y rigurosos formadores en distintas y muy valorables corrientes de las ciencias sociales. También mis agradecimientos a Lorena por la revisión de estilo de algunas partes del texto. Por último, toda mi gratitud a Monica por su apoyo y motivación continua en la elaboración de este trabajo. 


\section{Índice}

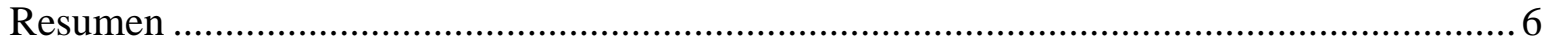

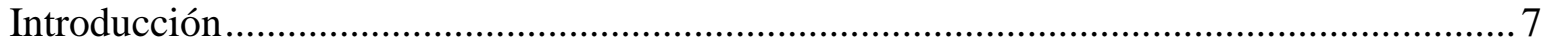

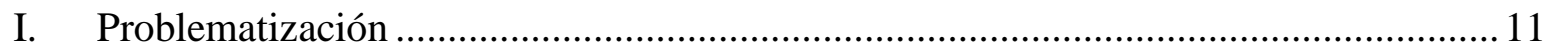

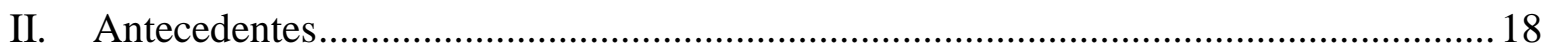

2.1. La genealogía del estudio de la crítica social ......................................................... 18

2.2 La desigualdad, el malestar y la legitimación en las últimas décadas en Chile .........23

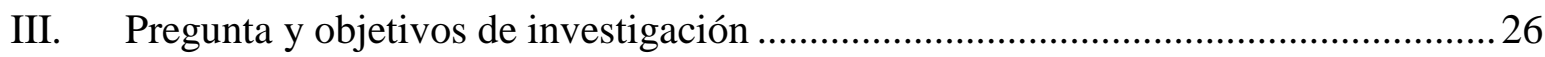

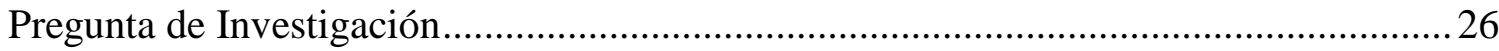

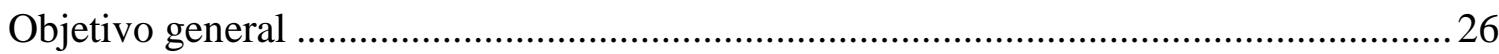

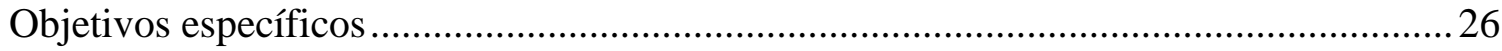

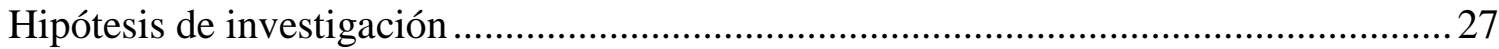

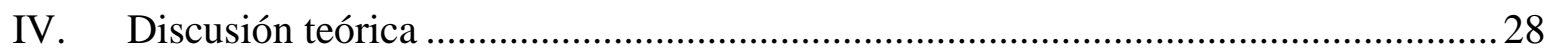

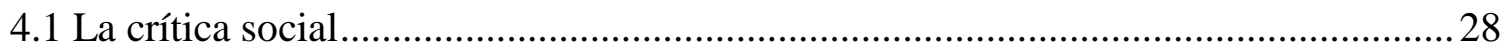

4.2 El rol de la crítica frente al problema de la reproducción y la transformación social 32

4.3 El enfoque de análisis morfogenético y pragmático......................................................37

4.4 De la crítica experta a la crítica ordinaria.................................................................... 41

4.5 La crítica social en su dimensión pragmática .............................................................42

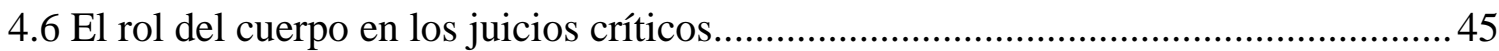

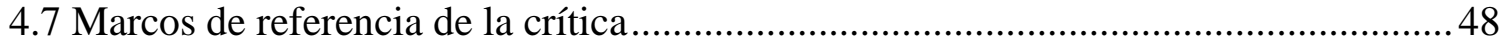

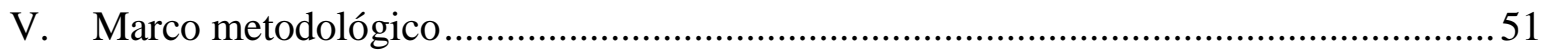

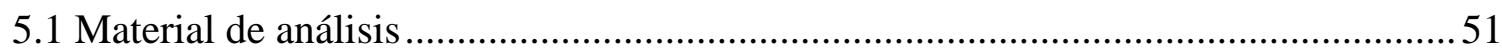

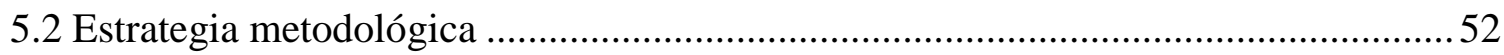

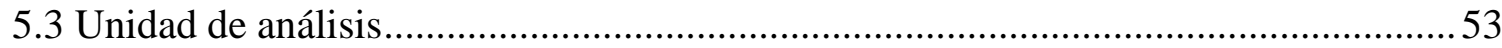

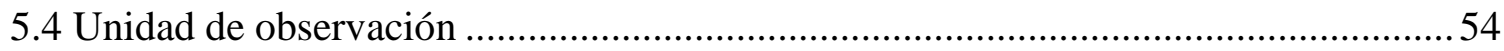

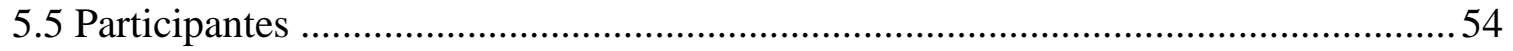


VI. La crítica ordinaria frente al espacio social ..................................................56

6.1 Las formas de la crítica............................................................................... 57

6.2 Los marcos de referencia de la crítica ...........................................................6 65

6.2.1 Igualdad de oportunidades: "se nota que el esfuerzo de él ha valido más que los

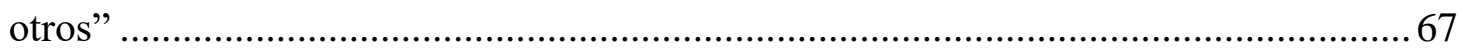

6.2.2 Igualdad de trato: "pero la sociedad no los trata a todos iguales" .....................78

6.2.3 Igualdad de posiciones: "En el país somos tan importantes todos, tanto el que está

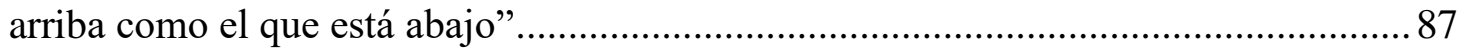

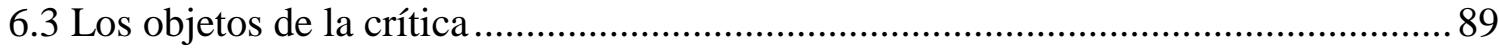

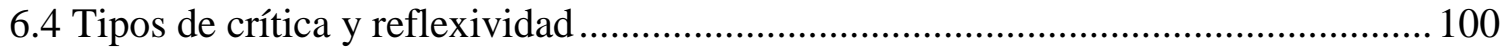

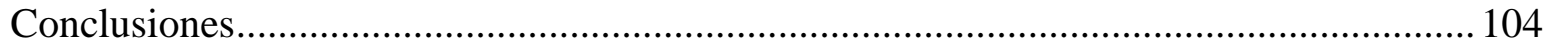

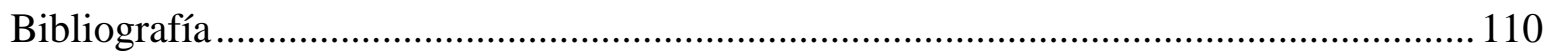




\section{Resumen}

La presente investigación aborda la crítica social ordinaria en Chile como un proceso que puede contribuir tanto a la reproducción del statu quo como al cambio social, a partir del análisis de las interacciones comunicativas en seis grupos de distintas clases sociales que participaron en un juego de clasificaciones. El enfoque de la sociología de la crítica de Luc Boltanski y el enfoque morfogenético o M/M de Margaret Archer son los principales referentes teóricos para el análisis, pues permiten una comprensión de la crítica en su contexto social de realización distinguiendo distintos niveles de la realidad social donde esta opera.

Siguiendo la distinción realizada por Boltanski, se propone diferenciar entre una crítica de tipo reformista y otra radical. Esta diferencia se asocia con los principios de justicia que sostienen los individuos según pongan en cuestión el orden social dominante o no. La variante reformista es la más frecuente en los juicios críticos de los participantes y se asocia a procesos de reproducción del orden social. Los principios de justicia son sistematizados en tres grandes marcos de referencia basados en tres formas de igualdad: de oportunidades, de trato y de posiciones. A través de estos marcos se condensan los principios normativos de los juicios críticos que se formulan hacia distintos objetos de la realidad social. Los resultados muestran que los objetos de crítica se encuentran en tres ámbitos principalmente: laboral, educacional y subjetivo. Adicionalmente, se plantea que la reflexividad juega un rol significativo en la crítica social, siendo un aliciente de su producción. En esta dirección, las críticas radicales son infrecuentes, aunque ilustrativas sobre una mayor elaboración de la crítica, asociándose a momentos de mayor reflexividad.

Por último, se muestra que es posible posicionar a la crítica como un fenómeno que tiende a reproducir sus condiciones de producción, es decir, el contexto social desde el que emerge. Aquello apunta a que la crítica ordinaria de las clases medias y la clase de trabajadores manuales refuerza los principios de justicia asociados al orden dominante y así contribuye a legitimar distintas formas de desigualdades sociales. En esta dirección, se vincula la crítica social con procesos de morfostasis social. 


\section{Introducción}

La presente memoria de título indaga en la crítica ordinaria y el rol que tiene en la reproducción de las desigualdades de la sociedad. A partir de las interacciones desplegadas en un juego colectivo, se problematiza la relación entre la crítica social, la reproducción del statu quo y el cambio social. Se profundiza en cómo opera la crítica de sujetos ordinarios pertenecientes principalmente a las clases medias del Chile contemporáneo, además de los trabajadores manuales. La reflexividad en la crítica constituye un punto de atención, ya que se propone como un referente importante para la elaboración de la crítica.

Crítica y crisis están íntimamente relacionadas. No solo comparten una etimología común krinos-; también han sido identificadas como dos caras de algunos procesos de transformación del orden social. Las teorías críticas, en su afán no solo por comprender o explicar la realidad social, sino también por transformarla, le han dado un papel importante a la crítica en esa demandante y disruptiva tarea. Estas líneas de producción intelectual han considerado gravitante el enjuiciamiento o crítica de su objeto de análisis como parte del proceso de transformación y, así, han propuesto que la intervención práctica sobre la realidad social supone un momento de elaboración crítica sobre la crisis diagnosticada.

Tradicionalmente la tarea de criticar fue relegada a una esfera experta, pero a fines del siglo $\mathrm{XX}$ se atiende también al proceso de crítica que sostienen los individuos comunes, es decir, la crítica de sujetos ordinarios o crítica ordinaria. La crítica social ordinaria ha sido un objeto de análisis principalmente a partir del giro realizado por Boltanski $(2011,2012)$ desde una sociología crítica hacia una sociología de la crítica. Tal movimiento tiene como objeto relevar las visiones subjetivas y parciales de los individuos no expertos. En otras palabras, se busca conocer cómo los individuos de a pie evalúan su contexto, con qué principios normativos y con qué consecuencias para el orden social.

La reproducción del orden social y su transformación son puntos de referencia para indagar en la relación entre la crítica y la praxis social, es decir, en lo que puede implicar el ejercicio de la crítica para la sociedad. Así, este trabajo se erige sobre los siguientes cuestionamientos generales ¿Cómo se sostienen órdenes sociales que producen desigualdades situando a ciertos grupos en posiciones dominadas y desaventajadas? ¿Cómo se estructuran los

principios normativos de justicia en ese contexto? ¿Cuál es el rol de la crítica en esa estructura 
normativa? La pretensión de esta tesis consiste en contribuir a esclarecer estas interrogantes, considerando evidencia de un contexto neoliberal avanzado, como es Chile de comienzos del siglo XXI.

La crítica consiste en un proceso social con un objeto de denuncia que emerge a partir de un malestar o percepción de injusticia que, a su vez, supone ciertos principios normativos en su base. Una de las razones que hacen de la crítica un instrumento de transformación es su inherente inconformidad con algún aspecto de la realidad, en la medida que se tiende a criticar lo conocido o experienciado en algún sentido. Desde esta perspectiva, transformar la realidad social implica conocerla y saber dirigir críticas hacia lo que se quiere cambiar, ya sea para convencer a otros de que adhieran al cuestionamiento o bien para identificar y proyectar los aspectos a ser transformados. Sin embargo, se ha reconocido que, junto a su potencial transformador, la crítica también posee un potencial para reproducir el statu quo. Cuando se critican aspectos de la realidad social, se utilizan principios normativos que provienen del contexto práctico, es decir, del mundo cotidiano de los agentes. Por esto, frente a situaciones o hechos que contraríen esos principios, se tiende a justificar el orden social utilizando distintos medios, incluida la crítica. En el caso de la crítica ordinaria, al tratarse de individuos no expertos, se hace especialmente significativo el contexto práctico como una fuente de principios normativos para la crítica.

Una discusión que cruza el debate sobre la crítica social es la existencia de desfases entre las condiciones de los individuos y los principios que suscriben; lo que algunos han conceptualizado como ideología. Pese a la ambigüedad del término según el uso que distintas corrientes intelectuales le han dado, el problema central refiere a cómo individuos y grupos sostienen creencias que pueden no ser beneficiosas o incluso perjudiciales para sí mismos. Se trata de una discusión que excede los límites de este trabajo, pero que contribuye a comprender el fenómeno de la crítica. La distinción propuesta por Boltanski (2011) entre una crítica reformista y otra radical es una orientación al respecto, ya que permite hacer el vínculo entre el contexto desde el que se critica y los principios normativos contenidos en los juicios críticos de los individuos.

Con el objetivo de hacer inteligible los principios de justicia de la crítica, los sintetizamos en tres grandes marcos de referencia que, como se verá, operan en los juicios críticos estudiados. 
Se trata de marcos cuyos núcleos apuntan a tres formas de igualdad: de posiciones, de oportunidades y de trato. En términos teóricos, constituyen grandes referentes respecto a las concepciones de la justicia social. Si bien puede predominar alguno en las normas de una sociedad dada, nunca aparecen de forma exclusiva. Mientras en algunas situaciones toman protagonismo los principios de igualdad de trato, en otras pueden ser gravitantes los principios de igualdad de oportunidades o de posiciones. Estos principios operan tanto a nivel colectivo como individual y coexisten en estos niveles. Además, en algunos casos pueden convivir de formas contradictorias, así como cuando alguien critica el maltrato vivido en la cotidianeidad, aduciendo que lo fundamental es que todos se traten bien sin miras a las diferencias sociales, a la vez que denuncia la falta de oportunidades en el mundo del trabajo o la discriminación producida por el tipo de educación poseída. Es a partir de estos marcos de referencia que se enjuician los objetos de la realidad social, con distintos resultados posibles para la estabilidad o cambio de la última.

La evaluación de los sujetos sobre el espacio social donde están insertos constituye un foco de atención a la hora de explicar la estabilidad de la realidad social. Si, según Forst (2014), todo orden social es un orden de justificaciones, la cuestión de qué y cómo se critica en un momento dado cobra particular relevancia, más aún cuando ese espacio social está cruzado por diversas desigualdades y posiciones sociales. De tal manera, para comprender la estabilidad o dinamismo de un orden social, se requiere comprender los alcances e implicancias de la crítica que allí tiene lugar. En esta dirección, atender a los objetos de crítica permite conocer la composición de esta en la sociedad y evaluar qué clase de justificaciones se construyen para sostenerlos como focos de atención.

La crítica social, además de componerse por marcos de referencia y objetos, se expresa a través de juicios críticos durante una interacción social que toma formas concretas. Por lo mismo, se trata de enunciados lingüísticos acompañados de expresiones no verbales que completan el sentido de la comunicación. Como se analiza más adelante, la relación entre la crítica social y sus formas de expresión -por ejemplo, a través del cuerpo- es relevante para evaluar indirectamente la reflexividad que cruza su comunicación.

En definitiva, el estado de las evaluaciones sobre la justicia social es fundamental para comprender las transformaciones y reproducciones de la sociedad. Más allá de lo que 
representan las críticas respecto al beneplácito individual con la realidad, de cuán molesta se encuentre una persona en particular con la realidad, comprender la crítica social a nivel supraindividual permite esclarecer patrones sociales que revelan cómo se sustenta o se debilita el orden normativo de la realidad social. De tal forma, por ejemplo, cuando todos critican las desiguales oportunidades que existen para desarrollarse laboralmente o en la educación, dan por sentado que la igualdad de oportunidades es un criterio de justicia fundamental. La crítica así no solamente expresa un estado de lo que podría denominarse opinión pública, al reconstruirse fuera del marco individual, sino que también da cuenta del estado de una sociedad.

El material analizado en esta investigación proviene de un trabajo colectivo más amplio. En particular, el juego de las clasificaciones -aplicado durante el año 2012- que se analiza en este trabajo fue realizado originalmente en el marco del proyecto Fondecyt regular 1130276 "Justicia social y tolerancia a la desigualdad: análisis subjetivo de la diferenciación social en un régimen neoliberal maduro", a cargo de la Dra. Emmanuelle Barozet. La investigadora generosamente ha puesto a disposición los datos para ser utilizados en esta investigación y, en conjunto con el Dr. Óscar Mac-Clure, han sido los principales interlocutores del presente trabajo. Una parte considerable de las discusiones teóricas aquí presentadas se desarrollaron al alero del Fondecyt regular 1130800 "Juicios sobre las clases medias: para una sociología de la crítica en Chile", a cargo del Dr. Mac-Clure y con la Dra. Barozet como coinvestigadora. Finalmente, cabe mencionar que colaboré en el análisis de los datos de ambos proyectos. 


\section{Problematización}

A la luz de los cambios en las últimas décadas que se han evidenciado en Chile, donde destaca la aparición de movimientos sociales en reivindicación de demandas territoriales, de género, ecológicas, de salud y, especialmente, educacionales, parece haber emergido una serie de sentimientos de malestar y sufrimiento moral a nivel individual (Araujo \& Martuccelli, 2012; PNUD, 1998) con un alto potencial crítico. Aquello no sólo ha reactivado las preguntas por la acción colectiva en un contexto neoliberal avanzado, también ha instalado el cuestionamiento por los mecanismos sociales que enlazan estos sentimientos de malestar individuales con las movilizaciones colectivas, considerando instancias intermedias donde proponemos se sitúa la crítica social. De esta manera, clarificar el rol de la crítica social en el contexto chileno es relevante para conocer cómo se engarzan estos niveles micro y macro.

La crítica se caracteriza, en términos generales, como la enunciación de una inquietud o de una denuncia, donde el emisor efectúa un cuestionamiento o una transgresión a una norma (Boltanski, 2011). Aquello supone que los individuos poseen un determinado marco de referencia para esa enunciación, el que está compuesto por principios de justicia que corresponden a las directrices normativas de lo que se considera aceptable y correcto -o inaceptable e incorrecto- respecto a ámbitos determinados. Entre los marcos de referencia pueden distinguirse al menos tres: igualdad de oportunidades, igualdad de trato e igualdad de posiciones. Estos son los grandes referentes que cimientan los principios de justicia detrás de la crítica social en la actualidad (e.g., Dubet, 2013; Tyler \& Blader, 2003).

Por otra parte, los objetos de la crítica pueden ser tan variados como lo permita la amplitud del espacio social ${ }^{1}$. Se puede criticar la desigualdad salarial, el rol de los gobernantes, las prácticas de otros ciudadanos, entre muchos otros aspectos del espacio social. En este caso, son de especial interés las críticas que tienen por objeto a las desigualdades sociales en general, entendidas estas últimas como el resultado de una distribución desigual de los recursos y oportunidades de una sociedad entre sus miembros, en el sentido matemático de la expresión (Bihr \& Pfefferkorn, 2008). El interés en las desigualdades sociales y su eventual crítica reside en que aparecen como focos de conflicto, al no corresponderse la distribución

\footnotetext{
1 Aquella metáfora planteada por Bourdieu (1991) para dar cuenta de un espacio multidimensional construido sobre los principios de diferenciación y distribución de propiedades sociales activas en el universo social, es decir, aquellas capaces de dotar de poder sobre tal universo a sus poseedores.
} 
de un recurso u oportunidad, sea cual sea, con la distribución que subjetivamente se considera que debiera prevalecer. Este desfase entre realidad y normatividad respecto a las desigualdades sociales además está cruzado por las distintas y desiguales percepciones que poseen los actores sobre las desigualdades sociales. En el cruce de estos tres elementos, las desigualdades sociales, la percepción subjetiva de estas y las premisas normativas sobre cómo deben distribuirse los recursos, es donde emergen cuestionamientos que varían en intensidad y que constituyen ciertos nudos problemáticos en la realidad social.

Si bien la crítica social es un concepto usualmente vinculado al conflicto y la transformación social, según se ha destacado su rol emancipatorio ${ }^{2}$ (Boltanski, 2011), no se puede reducir exclusivamente a este ámbito. En la medida que la crítica social se entiende como una acción donde se expresa una discrepancia entre el punto de vista de un sujeto respecto a una situación percibida y un marco normativo con que se juzga, esta aparece como un mecanismo social interesante, donde entran en juego principios de justicia, percepciones subjetivas frente a la realidad y acciones de denuncia. No es posible suponer desde estos elementos una orientación necesariamente emancipatoria de la crítica -incluso concediendo que puede establecerse concretamente qué apunta o no a la emancipación-, dado que en ningún caso es seguro que los principios de justicia y las percepciones sobre la realidad de los actores cotidianos apunten a la transformación de esta. Al contrario, autores como Pierre Bourdieu (2007) y Luc Boltanski (2011) han planteado que existe un sentido realista o práctico de los actores que hace que estos adecúen sus acciones al contexto donde las despliegan. Dado que la crítica es una acción, este sentido realista de los actores lleva a que también sea asociable con la reproducción del orden social y no sólo con la conformación de potenciales conflictos orientados al cambio social.

Así, Boltanski (2012) no pasa por alto que, en algunos casos, la crítica es un momento de la dominación, dada la capacidad que el capitalismo ha mostrado para asimilar principios que se erigen como crítica al mismo. En otro texto, el sociólogo junto a Chiapello señalan que:

\footnotetext{
${ }^{2}$ En términos generales, puede entenderse la emancipación como una orientación de la acción social dispuesta a acabar con alguna sujeción o dominación impuesta por un agente individuo o colectivo, o bien una estructura social. Se espera como resultado de esta un mayor grado de independencia y autonomía en el grupo o agente involucrado. La proclamación de emancipación de Lincoln en 1863, que liberaba legalmente a la mayoría de los esclavos en EE.UU. de tal condición, ilustra con claridad un proceso emancipatorio (que ciertamente no liberaba a la población afroamericana de toda dominación).
} 
El espíritu del capitalismo proporciona, al mismo tiempo, una justificación al capitalismo (que se opone a los cuestionamientos que pretenden ser radicales) y un punto de apoyo crítico, que permite denunciar la separación entre las formas concretas de acumulación y las concepciones normativas del orden social. (Boltanski \& Chiapello, 2002, p. 34)

A partir de la capacidad crítica del espíritu del capitalismo, las críticas anticapitalistas pueden ser morigeradas y desprovistas de su potencial de transformación. Si emerge una denuncia al carácter devorador y rapaz del capitalismo respecto a los recursos naturales, una respuesta posible es una crítica que apunta a la supresión de estos excesos a favor de otra forma de organización social sustentable en relación al medio ambiente. Como consecuencia, desde lo que Boltanski y Chiapello denominan el espíritu del capitalismo, se activa una crítica alternativa que, por ejemplo, reconoce la denuncia a la vez que plantea una solución basada en el mercado, como el sistema de bonos de carbono, donde se pueden transar los derechos a emitir contaminantes ${ }^{3}$.

Se torna relevante atender las implicancias que los juicios críticos tienen para la reproducción de las desigualdades sociales, ya sea que con estos se refuercen las posiciones de tolerancia de otros agentes frente al statu quo o que simplemente operen como un exorcismo de la actualidad, a modo de válvula de escape. Para el primer caso, se puede considerar el ejemplo del cambio climático, donde frente al problema de una producción excesiva de contaminantes en un modo de producción capitalista, se acepta el problema y se enuncian críticas que permitan mantenerlo sin el exceso. Cuando son realizadas por actores claves, como expertos o líderes políticos y sociales, tales críticas pueden llevar a legitimar una solución que no cuestione el modo de producción. El caso de los juicios críticos que sirven como válvula de escape puede ilustrarse con la prolífica línea de investigación en psicología social sobre los efectos de dar derecho a voz - por tanto, a enunciar críticas-sobre las percepciones de justicia (Van den Bos, 1999). La investigación en esta vertiente ha mostrado cómo las personas perciben resultados más justos cuando se les permite expresar su opinión -crítica o no-, más allá del resultado específico obtenido.

\footnotetext{
${ }^{3}$ Esta ilustración se basa en parte del debate que ha tenido lugar a propósito de las críticas al calentamiento global provocado por los niveles actuales de producción y emisión de contaminantes, especialmente en las críticas que han recibido los bonos de carbono como respuesta al problema (Ghouri, 2009).
} 
En un contexto de alta desigualdad económica, como el caso chileno (López, Figueroa, \& Gutiérrez, 2013), deben haber mecanismos que permitan sostener tal desigualdad y que contengan los sentimientos de indignación y malestar que esta pueda provocar. En esta línea, cabe relevar la idea de Schwalbe, Godwin, Holden, Schrock, Thompson y Wolkomir, al respecto:

Todos los arreglos sociales [social arrangements] consisten en personas haciendo las cosas en conjunto de manera ordenada y recurrente. Son esenciales para mantener estos patrones de acción los patrones de sentimiento. Tienen que haber, si no hay sentimientos de satisfacción, sentimientos de complacencia o resignación; tiene que haber miedo al cambio o miedo a ser castigado por protestar; y no debe haber mucha simpatía hacia los oprimidos o mucha ira hacia las élites. Sostener un sistema de desigualdad, uno que genera sentimientos de ira, resentimiento, simpatía y desesperación que son desestabilizadores, requiere que las emociones sean administradas [managed]. (2000, p. 434 traducción propia).

La crítica, como un fenómeno que lidia con sentimientos de malestar, a la luz del sentido realista de los actores, forma parte de lo que debe administrarse en una sociedad desigual, es decir, requiere ser considerada para un gobierno sostenible de tal sociedad. De tal forma, los juicios críticos se reconocen como una operación que no sólo propicia el cambio social, sino que también pueden reforzar el estado de las cosas. Aquello también se vincula con el nivel de reflexividad asociado a la crítica. No obstante la crítica ordinaria sea por definición una de carácter no experto, puede poseer distintos niveles de reflexividad entendidos como grados de elaboración o trabajo cognitivo de trasfondo. Aquello, proponemos desde Boltanski y Archer ${ }^{4}$, puede ser crucial para la forma que toma la crítica.

También debe considerarse que el reciente e inesperado surgimiento de movimientos sociales tiene una impronta mesocrática en el caso de Chile. Es así como Carlos Ruiz apunta sobre los procesos de movilidad educacional acaecidos en las últimas décadas: "Esta suerte de movilidad profusamente endeudada abre nuevos malestares, en estos nuevos grupos medios, que se aúnan a la protesta de las viejas fracciones medias "desarrollistas" con mayor capacidad de elaborar el discurso del malestar" (2013a, p. 92). Este fenómeno tiene lugar en

\footnotetext{
${ }^{4}$ La relación entre reflexividad y tipos de crítica es desarrollada más adelante, en el capítulo IV.
} 
un contexto general donde se constata la continuidad, a partir del golpe de estado de 1973 hasta la actualidad, de una forma de dominación política y social liderada por los nuevos grupos empresariales que emergieron después del conflicto, en alianza con antiguas fortunas (Ruiz E. \& Boccardo, 2014). Esta nueva forma de dominación viene de la mano de la materialización particular del capitalismo para el contexto chileno, es decir, el régimen neoliberal avanzado, cuyas bases se encuentran en ciertas directrices económicas, pero cuyos efectos exceden con creces este ámbito, transformándose el mercado en un mecanismo de (des)orden social (Garretón, 2012; Ruiz E., 2013b). En relación a este orden neoliberal, Ruiz y Boccardo apuntan que:

Es que se suponía que el "milagro chileno" había logrado satisfacer las expectativas de una importante mayoría de la población. En especial, de aquellas facciones sociales propias de la pujante "clase media" que asciende con la modernización neoliberal. Pero se trata de unas expectativas que terminan de hacer crisis en el quinquenio que corre entre 2006 y 2011, en el que irrumpe, en forma creciente, un malestar largamente incubado y socialmente muy extendido, de dimensiones que exceden con creces la mera cuestión educacional. (2014, p. 135)

Este paulatino malestar no se incorpora de igual forma en la población, pues en Chile no se constata una relación directa entre la desigualdad económica, su percepción y su justificación (J. C. Castillo, 2009, 2012a; J. C. Castillo, Miranda, \& Carrasco, 2012). Por un lado, "los quintiles más bajos perciben una brecha salarial menor que aquellos grupos con mayores ingresos" (J. C. Castillo, 2009, p. 260), a la vez que no son los sectores de menores ingresos los que menos legitiman las brechas salariales percibidas, como podría intuirse (J. C. Castillo, 2012b; Ibáñez, 2013). Es por esto que las clases medias constituyen un sector de particular interés para analizar cómo opera la crítica social.

Asimismo, resalta la importancia de las clases medias en la fisonomía social del Chile actual, que se encuentra marcada por un proceso de mesocratización precaria (Barozet \& Espinoza, 2012; Barozet \& Fierro, 2011; Ruiz E. \& Boccardo, 2011). Tal proceso ha ido acompañado de unas narrativas sobre las clases medias que, al menos desde el periodo del Frente Popular, han configurado y contenido el conflicto social desde los actores políticos (M. Castillo, 2011). En suma, a la luz de lo expuesto, las clases medias son grupos sociales que concitan 
un alto interés para el estudio de la crítica social, tanto por su relevancia en la fisonomía social del Chile contemporáneo, como porque algunas de sus franjas han manifestado un descontento con el presente estado de las cosas. En ellas se encuentran importantes focos de experiencias y sentimientos de injusticia, así como referentes sociales para otros actores. Aun así, al poner el foco en las clases medias no se busca homogeneizar de antemano los juicios críticos, pues al existir una importante heterogeneidad en estas clases, no puede suponerse, $a$ priori, uniformidad en la crítica social que emana de las mismas. Juan Pablo Velasco, analizando parte del material que se utilizará más adelante, encuentra que "la desigualdad persistente [...] en Chile es abordada críticamente por el segmento alto de los sectores medios que participaron en la investigación” (2013, p. 133), en tanto reconocen actitudes discriminatorias y excluyentes especialmente en quienes han ingresado hace poco a la parte alta de la estructura social. Por otro lado, escribe que "para los sectores medios, sobre todo los segmentos medio y bajo, la educación es uno de los principales factores legitimantes de la desigualdad persistente" (Velasco, 2013, p. 134). Estos resultados muestran, en primer lugar, la aparición de interacciones que contienen juicios críticos sobre las desigualdades, a la vez que estas últimas son problematizadas a través de factores de legitimación hacia la desigualdad de manera diferente según las distintas clases medias. Se habla de legitimación en el sentido de ideologías compartidas sobre una aceptación de determinados fenómenos sociales, como una distribución económica altamente desigual, a la que se suscribe individualmente, incluso aunque no se esté beneficiado por la misma (J. C. Castillo, 2011). Entonces, en principio, las heterogéneas clases medias erigen críticas que se diferencian, por ejemplo, según los distintos grupos que las componen. Por otra parte, al caracterizar cómo reaccionan los individuos frente a personajes ficticios de la élite chilena, se ha mostrado cómo la crítica varía según su objeto: "Una vez develada cognitivamente la identidad de la élite económica, se le juzga críticamente, en especial a la élite tradicional, y en menor medida a la élite reciente, en contraste con una valoración más positiva de la clase media" (Mac-Clure, Barozet, \& Moya, 2015, p. 17), así como también se manifiestan diferencias en los juicios críticos según las distintas clases medias: "En esa crítica influye principalmente la clase social de las personas" (Mac-Clure et al., 2015, p. 17).

Lo que se busca desentrañar aquí es la naturaleza de los juicios críticos tomando en consideración el contexto en que estos se despliegan y los efectos que producen en el mismo. 
A primera vista, destaca el rol de los agentes en la crítica social, pues esta se funda en una enunciación proveniente de un individuo determinado. No obstante, también existen factores estructurales y culturales que juegan un rol importante a la hora de comprender este fenómeno. Como un enunciado lingüístico que tiene lugar en un contexto, los juicios críticos tienen un importante potencial analítico desde un enfoque pragmático donde se relevan los aspectos contextuales y las implicancias prácticas de los intercambios lingüísticos. De tal manera, ya que la crítica tiene lugar a través de intercambios lingüísticos contextualizados, para avanzar en su comprensión se debe disponer de un enfoque pragmático. La aproximación a la crítica social como un mecanismo inserto en la sociedad destaca su carácter procesual, en el sentido en que otros autores han estudiado los mecanismos de reproducción de la desigualdad (Schwalbe et al., 2000; Tilly, 2000) o en que Becker (2009) consideró la desviación a las normas. Se trata de entender, en este caso, la crítica social como un proceso que se construye socialmente y que se transforma en el tiempo.

Han existido principalmente dos obstáculos para dar cuenta del rol de los juicios críticos en la realidad social. En términos epistemológicos, según Boltanski (2011) se ha desestimado el valor de los juicios críticos ordinarios, es decir, de aquella crítica que emerge desde la cotidianeidad de los actores sociales, en favor de una crítica experta. La sociología crítica de Pierre Bourdieu (e.g. 2007, 2012) o la teoría crítica de autores vinculados a la escuela de Frankfurt como Theodor Adorno y Max Horkeimer (e.g. 2007) son una ilustración de aquello. Una perspectiva pragmática de la crítica, en cambio, rescata el valor de los juicios que provienen de contextos no expertos, en tanto son un complemento necesario que permite figurar los procesos de crítica en su totalidad, además de representar un objeto de sociológico interesante por sí mismo.

Por otra parte, metodológicamente es difícil acceder a contextos de crítica cotidiana de manera satisfactoria, pues son situaciones que no promueven las técnicas de investigación más usadas en la sociología, como las encuestas, las entrevistas y los grupos focales. La crítica ordinaria se da entre pares, en espacios de intimidad, en la soledad, aunque hoy en día se la pueda encontrar cada vez más en las redes sociales. En esta dirección, en la década de los ochenta, Boltanski y Thévenot (1983) crean un dispositivo de investigación basado en juegos de interacción entre personas con el que se facilita la aparición y observación de 
situaciones cotidianas. El contexto de interacción propiciado por estos dispositivos es relevante, pues no se trata solamente de observar cuáles son los juicios críticos particulares de cada individuo, sino más bien de analizar cómo se despliegan estos colectivamente, generando reacciones entre quienes interactúan. De tal forma, los juegos inspirados por la iniciativa de Bolstanki y Thévenot para el caso chileno y analizados en esta tesis fueron diseñados siguiendo las directrices de aplicaciones previas, por lo que constituyen dispositivos idóneos para la observación de la emergencia de los juicios críticos en un contexto de interacción. Se trata de dispositivos que funcionan a través de la participación colectiva de hombres y mujeres, principalmente de clases medias, que interactúan y se comunican a partir de las pautas otorgadas por una moderadora. Estos juegos corresponden al juego de las clasificaciones, descrito en el capítulo V.

\section{Antecedentes}

\subsection{La genealogía del estudio de la crítica social}

Si bien se identifica un momento fundacional en el estudio de la crítica ordinaria en los estudios de Boltanski durante la década de los ochenta (2011, 2012), especialmente en el trabajo realizado con Laurent Thévenot (Boltanski \& Thévenot, 1983), esta línea de estudios es parte de una genealogía. La agenda teórica del sociólogo francés es heredera de la sociología crítica, donde destaca el trabajo de quien fuera su maestro, Pierre Bourdieu. Se trata de una sociología crítica en el sentido de que se elabora una posición normativa (Brunkhorst, 2014) a partir de una descripción científica de la realidad. En un sentido general, estas agendas de investigación se insertan en el marco de las teorías críticas (Keucheyan, 2013) donde también se incluye al marxismo, el estructuralismo, el operaismo italiano, los estudios culturales, los estudios de género, los estudios postcoloniales, el postestructuralismo, entre otros.

En términos simplificados, ilustramos cómo opera la sociología crítica: en un espacio social donde existen agentes dominantes y dominados - ya sea por raza, clase, género, nacionalidad u otros criterios-, se establecen las características de tal o cual proceso de dominación, mostrando cómo se han construido y establecido históricamente esas posiciones desiguales. Aquello va acompañado de una denuncia sobre lo espurio de tal dominación. En la medida que el experto devela el origen objetivo de una dominación -como que un rey no es tal por 
derecho divino, sino por gracia de disputas políticas y correlaciones de fuerza actuales y de generaciones pasadas-, se pone en evidencia que ese origen no se condice con lo que se ha declarado tradicionalmente como su fundamento o con los principios socialmente legítimos para aceptar el estado de las cosas en el presente. En otras palabras, la dominación que se aceptaba como legítima es puesta en cuestión por el análisis de la sociología crítica. De tal forma, junto al diagnóstico, descripción y explicación de la realidad social, el científico social levanta una crítica a esta.

La pregunta que plantea Boltanski, como un complemento a este ejercicio intelectual crítico, es ¿cómo las personas comunes y corrientes consideran estas situaciones de dominación e injusticia? Su propuesta apunta a incorporar la reflexión misma de las personas ordinarias, dando cuenta de cómo estos agentes perciben y denuncian la realidad social. Guerrero y Ramírez reconstruyen la tarea del sociólogo en la sociología de la crítica:

observar los casos prestando atención a la manera como las personas despliegan sus capacidades interpretativas frente a aquello que sucede cuando alguien formula una demanda de injusticia. Esta observación sociológica debe realizarse evitando juzgar desde el punto de vista externo y superior del científico - el grado de validez de las interpretaciones (de los juicios y de las críticas) expresadas por los actores partícipes del proceso. Más bien, el sociólogo debe analizar el grado de validez que los actores mismos le otorgan a las distintas interpretaciones que entran en juego y que se enfrentan cuando surge un caso. (2011, p. 45)

Por lo mismo, existe un quiebre epistemológico en la postura de Boltanski, en tanto apuesta por un conocimiento desde los actores ordinarios, alejándose de la exterioridad cientificista que adoptarían otras perspectivas, como el estructural-funcionalismo o el marxismo althusseriano.

Sobre las teorías críticas en Occidente del último tercio del siglo XX hasta la actualidad, entendidas en un sentido laxo y no restringido al Instituto de Investigación Social de Frankfurt, Keucheyan (2013) destaca la relación que existe entre su contexto de producción, marcado por la derrota de la izquierda, y su contenido, que describe como de alta abstracción en comparación a elaboraciones previas. Como evidencia de esta mayor abstracción, Keucheyan menciona el origen disciplinar de los nuevos autores, quienes eran mayormente 
filósofos, estetas y epistemólogos. Asimismo, es evidente la separación contemporánea entre los productores de teorías críticas o intelectuales, mayormente situados en contextos académicos, y los líderes de movimientos políticos y sociales. Aquello tiene un fuerte contraste con las figuras que fueron determinantes tanto en la producción intelectual como en la conducción de importantes procesos socio-políticos entre la segunda mitad del siglo XIX y las primeras décadas del siglo XX, tales como Karl Marx y Vladimir Lenin. Este proceso de separación entre una práctica política activa y la producción de teoría crítica aparece progresivamente desde finales del siglo XIX hasta la actualidad. Perry Anderson en Consideraciones sobre el marxismo occidental (1981) da cuenta de cómo la derrota de la Revolución espartaquista (Novemberrevolution) entre 1918-1923 y el aislamiento de la revolución rusa en la década de 1920 -que incluyó el establecimiento de un marxismo ortodoxo- fueron un punto de inflexión en la separación de estas dos actividades, estrechamente vinculadas hasta ese momento en la tradición marxista. En esta dirección, Keucheyan enuncia que el período siguiente en el marxismo occidental "nació de la borradura de las relaciones entre los intelectuales/líderes y las organizaciones de la clase trabajadora que habían existido en el marxismo clásico" (2013, p. 10 traducción propia). Los representantes de este último período son intelectuales como Antonio Gramsci y Georg Lukács. Luego, la separación se profundizará por otros factores, como la profesionalización de la actividad intelectual en las universidades. También verá otro hito durante la década de 1970, cuando comienza a tomar forma un nuevo tipo de capitalismo, el neoliberalismo, mientras que paralelamente proliferan diversas corrientes de teorías críticas, principalmente en EE.UU, aunque también en espacios considerados más periféricos como Asia y América Latina.

Ahora bien, la importancia de la acción política para las teorías críticas se desprende de la capacidad transformadora (o reproductora del statu quo) de la primera. Es decir, la dimensión normativa de las teorías críticas que acusa la existencia de distintas injusticias necesita -o al menos supone que existe - un instrumento que permita dar curso a los cambios necesarios para alcanzar un orden más justo. La política se convierte así en un objeto relevante para las teorías críticas y, por lo mismo, la progresiva separación entre la producción intelectual y la acción política es preocupante para las mismas. Para Keucheyan este alejamiento es parte de la derrota vivida por la izquierda en el siglo XX. Al ser la política una herramienta 
fundamental para llevar a cabo cambios sociales deliberadamente, el que la producción intelectual se escinda de la esfera política socava la capacidad de incidencia de la primera.

Desde Chile y con un énfasis en una tradición filosófica que incluye a Sócrates y Arendt, Sergio Micco (2014) ha destacado una clara distancia entre la producción intelectual y la política como un espacio de debate y acción. Para Micco, esta distancia tiene efectos perjudiciales en la sociedad: su exacerbación lleva al totalitarismo, en tanto forma de gobierno que sostiene una dominación social fuerte a través de una ideología de Estado que, en definitiva, termina por negar lo humano (Arendt, 2006). El chileno, así, hace un llamado de atención respecto a la necesidad de que los intelectuales se involucren en el quehacer político, relevando la necesidad recíproca entre políticos e intelectuales: “el intelectual al momento de decir al mundo su verdad y el político cuando busque dotar de ideas su vocación de poder; las ideas sin poder son impotentes, como son ciegas las políticas sin ideas" (Micco, 2014, p. 28). Ya que el intelectual está inserto en el mundo que analiza, Micco considera que “el intelectual debe gozar de independencia crítica pero jamás ser indiferente a los dolores del mundo en el que le tocó vivir y que le regaló lengua, cultura y vocación” (2014,p. 17).

En la historia de la filosofía chilena aparece una tensión entre programas de investigación que consideran insoslayable abordar problemas de la realidad social, frente a otras líneas que apelan a un desarrollo inmanente de la disciplina. Al estudiar el desarrollo de la filosofía chilena, Iván Jaksic afirma que este

puede ser entendido en términos de la tensión entre aquellos filósofos que han considerado que la disciplina es un instrumento para el análisis y el cambio de la sociedad, y aquellos que conciben que la filosofía es, ante todo, una disciplina académica que, aunque se encuentra afectada por grandes cambios sociales y políticos, depende de su propia evolución histórica para nutrirse y desarrollarse. (2013, pp. 26-27)

Esta descripción del devenir filosófico chileno da cuenta de un proceso que otras disciplinas académicas también han visto, acentuado por los procesos políticos del siglo XX que han enfrentado dentro y fuera de las aulas a intelectuales nacionales. En particular, cabe destacar que durante la dictadura las carreras universitarias de humanidades y ciencias sociales fueron miradas con especial sospecha, reprimiendo tanto a organizaciones académicas como a miembros de sus comunidades (Garretón, 2005). 
En lo que respecta a los estudios sobre la crítica social en Chile en los últimos años, se han realizado investigaciones que abordan una línea más teórica (Basaure, 2011, 2014) y otras que hacen un acercamiento empírico a la crítica ordinaria en el país (Barozet \& Mac-Clure, 2014, 2015; Mac-Clure et al., 2015). Mauro Basaure ha dialogado principalmente con algunos miembros contemporáneos de la Escuela de Frankfurt y con Luc Boltanski, profundizando las relaciones entre estas dos agendas teóricas, así como ha abordado directamente el tema de la crítica social y la justificación. Por otra parte, Barozet, Mac-Clure, Méndez y Guzmán (2017) han estudiado empíricamente, siguiendo los estudios de Boltanski y Thévenot (1983), cómo las personas ordinarias categorizan el espacio social, donde destacan la existencia de una dimensión normativa - por tanto, crítica- en las categorías que usan distintos grupos para ordenar a las personas en la sociedad. También Mac-Clure, Barozet, Valenzuela y quien escribe (2015) han estudiado cuáles son las críticas que realizan personas de distintas clases sociales hacia la élite chilena.

En suma, existe una nítida genealogía dentro de las teorías críticas que consideran desde el marxismo clásico ${ }^{5}$ hasta la sociología de la crítica -focalizada en describir y explicar la crítica de personas ordinarias-y otras corrientes actuales. El patrón general ha estado marcado, de una parte, por la separación entre la actividad política y la producción intelectual, así como por otra parte, ha mostrado al menos tres posiciones respecto a la realidad analizada. En el primer caso, principalmente en el marxismo clásico, existió una fuerte tendencia al análisis empírico de temas coyunturales que, además, iban de la mano con una experiencia intensa en el campo político. Una muestra de esta línea se encuentra en los análisis de coyuntura de Marx, tales como 18 Brumario de Luis Bonaparte (2003 [1852]). Luego, en la medida que se produce la separación entre la práctica política y la producción intelectual, hay un mayor grado de abstracción en los temas estudiados, acompañado de una posición de análisis que pretende una exterioridad. La producción de Louis Althusser (1988), Maurice Godelier (1976) o Nicos Poulantzas (1979), abordando diversos temas desde perspectivas marxistas ilustra esta forma de producción intelectual. Desde la década de 1980, corrientes más contemporáneas, como la de Boltanski, realizan un giro epistemológico, intentando acceder a la realidad social desde los sujetos ordinarios, aunque se mantiene o incluso se acrecienta

\footnotetext{
${ }^{5} \mathrm{Si}$ bien esta genealogía puede extenderse hacia atrás en el tiempo al utilizarse criterios más laxos de delimitación, nos ceñimos aquí al período abordado por Anderson (1981) y Keucheyan (2014).
} 
la distancia con la práctica política, buscando romper con la superioridad moral y analítica del sociólogo por sobre eso sujeto ordinario. El caso chileno no es la excepción a esta disociación entre teoría y política (Micco, 2014), que también ha sido un proceso histórico donde ha entrado en tensión una lógica de desarrollo académico inmanente frente a otra dinámica de involucramiento entre las disciplinas y los problemas del mundo social.

\subsection{La desigualdad, el malestar y la legitimación en las últimas décadas en Chile}

Desde la década de 1990 se han elaborado interpretaciones sobre los efectos sociales del neoliberalismo instaurado en Chile durante la dictadura militar (1973-1990). Tomás Moulian (2002 [1997]) destacó los efectos de una cultura de consumo, donde la vida social se comienza a mercantilizar de la mano de la ampliación del crédito, generando condiciones restringidas para el desarrollo de la ciudadanía. En el informe anual de 1998, el Programa para el Desarrollo de las Naciones Unidas advertía sobre una desconfianza en las relaciones interpersonales como en las relaciones entre las personas y las instituciones, lo que contrastaba con el éxito macroeconómico del país. Consignaba que "los éxitos de la modernización emprendida corren en paralelo a una sensación latente de malestar" (PNUD, 1998, p. 34). Frente a un crecimiento económico constante, la distribución del ingreso no mejoró. Se mantenía una alta desigualdad económica que parecía legítima ya que, fuera de esa sensación latente de malestar, no se expresaban descontentos a nivel masivo y público.

Para Norbert Lechner, la sociedad de consumo que se había consolidado incluía una naturalización del estado de las cosas:

Lo social adquiere el halo de un "sistema" objetivo y abstracto que se desarrolla acorde a una lógica específica. Según esa imagen, las personas podrían aprovechar dicha "lógica de sistema" acorde a su racionalidad instrumental, pero no pueden someterla a sus

necesidades y deseos. Por así decir, pueden usar la lógica del mercado como quién se adapta al sol y la lluvia, sin poder modificar el rumbo de las nubes. (2007, p. 485)

Tal naturalización viene a ser cuestionada por los distintos movimientos sociales que levantaron reivindicaciones en distintos ámbitos desde el año 2006, a partir de la movilización de los estudiantes secundarios (Rojas, 2012; Ruiz E. \& Boccardo, 2014). Al parecer, ese malestar, diagnosticado una década atrás, tomaba cuerpo más allá de las individualidades y sacaba la voz respecto a las injusticias percibidas en los ámbitos de las 
desigualdades territoriales, de género y educacionales, entre otras. Aun así, estos conflictos han sido intermitentes y parecen estar siendo procesados por el sistema político tradicional.

Esta naturalización, por otro lado, contrasta con la constatación de principios de igualdad y equidad presentes en Chile a comienzos del siglo XXI (Garretón \& Cumsille, 2002). A la luz de este contraste, puede considerarse la existencia de una disonancia cognitiva, donde los principios de justicia que subyacen a los actores no se condicen con el despliegue en la práctica de las personas. Según Ismael Puga, esta disonancia no es tal, pues "los actores se encuentran cognitivamente conscientes respecto de las contradicciones entre sus modelos normativos y sus percepciones de lo real, pero actúan de modo que disuelven esa contradicción en su práctica" (2011, p. 158). Lo que ocurre es que la naturalización alcanza tal fuerza que "la modificación de la realidad en un sentido consistente con lo que aparece como 'justo' aparece explícitamente como imposible” (Puga, 2011, p. 158). En suma, Puga sugiere que "la desigualdad social en Chile no posee legitimidad social, y sobre todo que la legitimación de tal desigualdad se desarrolla de modo conflictivo y problemático para los actores" (2011, p. 158).

A comienzos de la segunda década del siglo XXI, Juan Carlos Castillo (2011) precisa el análisis sobre la legitimidad de la desigualdad en Chile en el ámbito de la desigualdad de ingresos. Encuentra que las diferencias entre lo que se percibe y lo que se considera justo no varía significativamente entre distintos grupos de estatus, por lo que propone la existencia de un consenso en relación a la percepción de la desigualdad de ingresos. Si bien reconoce que los principios utópicos, como los de igualdad, juegan un rol relevante en la legitimación de la desigualdad, el referente central de cómo deberían ser las cosas se basa en cómo son en la actualidad. En definitiva, plantea que el contexto importa como un estándar de referencia para los juicios normativos, como son los juicios críticos. En el caso de Chile, donde se evidencia un contexto de alta desigualdad económica (López et al., 2013), este constituiría entonces la principal base de referencia para legitimación de tales desigualdades.

La idea de que existen variaciones sustantivas en las formas de percibir la realidad según grupos basados en ocupaciones, como las clases sociales, es reafirmada por los hallazgos de Pablo Pérez (2014), quien muestra que los patrones de conciencia de clase en Chile están moldeados por la posición de clase y por el origen de clase, en tanto indicador este último de 
experiencias de clase. En la línea del trabajo de Wright y Shin (1988) en Estados Unidos, en su estudio Pérez muestra que los intereses de clase y la identidad de clase ${ }^{6}$, ambos componentes de la conciencia de clase, evidencian orientaciones ideológicas propias de esas clases sociales, dando forma a la apropiación subjetiva que sus integrantes tienen de la realidad. Por otra parte, Carvacho y colegas (2013) analizan los prejuicios de la población hacia distintos grupos sociales en Chile y muestran que la clase obrera-que corresponden en el estudio a quienes poseen menores ingresos y nivel educacional- tiende más que otras clases a legitimar el orden social.

Tomando en consideración estos antecedentes, se evidencia que existe un buen pie para analizar la crítica social en Chile, pues pese a que exista una legitimación de las desigualdades, esta no estaría exenta de problemas y de principios de justicia enfrentados. En tal sentido, es en esos problemas y enfrentamientos donde aparecen experiencias de injustica o de sufrimiento moral que muchas veces se traducen en juicios críticos.

\footnotetext{
${ }^{6}$ Se trata de una aproximación empírica a la conciencia de clase que considera a esta como los aspectos de la conciencia de una persona que tengan un contenido identificable de clase (Wright \& Shin, 1988). La identidad de clase se refiere a "las formas en que las personas se consideran a sí mismas 'miembros' de diferentes clases" (Wright \& Shin, 1988, p. 67 traducción propia) y se ancla en la trayectoria personal. Los intereses de clase, en cambio, refieren a una dimensión proyectiva de las personas y se corresponden con la posición en la estructura social que estas ocupan.
} 


\section{Pregunta y objetivos de investigación}

Para indagar en el campo de la crítica social desde la perspectiva de los actores ordinarios en Chile es pertinente elaborar una caracterización de los tipos de juicios críticos. Como se ha visto, la crítica social tiene una estrecha relación con los procesos de transformación y reproducción de la sociedad, ya que da luces sobre los criterios normativos que subyacen a los juicios críticos y, por tanto, permite delinear las orientaciones de acción futuras. No obstante, no es claro en qué forma ocurre esto en la interacción donde se lleva a cabo la crítica social. Dentro de los antecedentes históricos recientes, se ha visto que las clases medias tienen un rol importante en la generación y manifestación de sentimientos de injusticia y malestar. En esta línea, la pregunta de investigación que orienta este trabajo es:

\section{Pregunta de Investigación}

¿Qué tipos de crítica social surgen en las clases medias del Chile actual y cómo se relacionan con los procesos de cambio y reproducción social?

Esto se traduce en un trabajo comprensivo sobre las interacciones en grupos de participantes de las mismas clases sociales realizados durante 2012, formulado bajo el siguiente objetivo general:

\section{Objetivo general}

Comprender la relación entre los tipos de crítica social a la luz de los procesos de reproducción y cambio social en un contexto de interacción.

Este objetivo comprende los siguientes objetivos específicos:

\section{Objetivos específicos}

- Distinguir los tipos de juicios críticos en el contexto de los juegos.

- Relacionar los principios de justicia que subyacen a la crítica social con sus efectos pragmáticos en términos de reproducción y cambio social.

\section{- Identificar los niveles de reflexividad en que operan los juicios críticos.}

Se propone una hipótesis cualitativa de trabajo que, como tal, es amplia y flexible (Hernández, Fernández, \& Baptista, 2010). Dada la posibilidad de diferenciar distintos tipos de crítica social según los niveles de reflexividad en que se enuncia, se plantea una hipótesis que vincula a estos con los efectos de cambio o reproducción de las desigualdades sociales, 
hipotetizando que los momentos de baja reflexividad se relacionan con una crítica reformista y los de alta reflexividad pueden llevar a una crítica radical. Así, proponemos:

\section{Hipótesis de investigación}

La realización de juicios críticos muestra distintos niveles de reflexividad, según los cuales se pueden establecer asociaciones hacia el cambio y la reproducción de las desigualdades sociales.

Tal hipótesis sirve como orientación para el análisis bajo el supuesto de que es posible distinguir al menos dos niveles de reflexividad: alto y bajo. Estos niveles se evidencian en el grado de elaboración de los juicios críticos, así como en aspectos de la comunicación no verbal relacionados con la dimensión práctico-discursiva de la crítica, por ejemplo, como se ve en al análisis del capítulo VI, el nivel de atención frente al juicio crítico emitido por alguien o la disposición corporal con que emiten o reciben los juicios críticos. Cabe destacar que es posible realizar un análisis de este tipo gracias al registro audiovisual de los juegos. 


\section{Discusión teórica}

\subsection{La crítica social}

La crítica social es un concepto complejo que comprende distintos niveles y varía según sus contextos de realización. En la tradición sociológica, como destaca Boltanski (2011, 2012), se ha relevado mayormente la crítica intelectual o académica, que tiene como epítome a la sociología crítica. Esta última consiste en aquella práctica sociológica que incorpora aspectos normativos, alejándose de un paradigma positivista o post-positivista, y que toma una posición sobre su objeto de análisis, por ejemplo, sobre los efectos de un régimen político y social dominante. No obstante, siguiendo al sociólogo francés, la crítica también aparece en la cotidianeidad de la vida social, en tanto corresponde a un tipo particular de juicios morales que todos los actores ordinarios realizan. Así, la crítica ordinaria es una dimensión de particular importancia de este fenómeno, que debe ser tomada en cuenta para comprenderlo.

La crítica consiste en una acción, generalmente lingüística, que tiene determinados efectos en la realidad social. Boltanski (2011) se refiere a la crítica como la enunciación de una inquietud o de una denuncia, donde el emisor efectúa un cuestionamiento o una transgresión a una norma. En términos más precisos, siguiendo la definición de Mac-Clure et al:

Se entiende por crítica la expresión de una discrepancia entre una situación y un referente de acuerdo al cual los actores sociales formulan su juicio [...] La crítica implica una interpelación a lo establecido que es expresada retórica o discursivamente, por lo que consiste en un paso más allá de un sentimiento o percepción de injusticia. (2015, pp. 2-3)

De tal forma, considera un componente agencial fuerte, en tanto su realización requiere una expresión, es decir, la activación de un agente individual o colectivo. Es en esta línea que cabe hacer una diferencia, aunque parezca sutil, entre los juicios críticos y la crítica social, siendo los primeros componentes de la última. Lo que delimita la crítica social es su contenido. Así, por ejemplo, se puede hablar de la crítica hacia la posición económicamente privilegiada de las élites, tomándolas en su posición relativa en el espacio social como un objeto de la crítica. En cambio, la forma de la crítica varía según el o los juicios críticos que la configuran. La crítica social se vincula tanto con el elemento que toma por objeto, es decir lo que es criticado, como con el marco de referencia desde el que se efectúa, el contexto normativo en que esta opera. Tal marco está compuesto por determinados principios de 
justicia que, en tanto directrices normativas, al constatar una situación o fenómeno en la realidad social que no se corresponda con estos, puede dar pie a una denuncia. Esta denuncia consiste en hacer explícita una transgresión a alguna norma; aquello no se limita a transgresiones legales de normas, también puede apuntar a cualquier acción o situación moralmente ilícita.

En la definición del objeto de la crítica y de su marco de referencia juegan un rol primordial la estructura y la cultura, en un sentido archeriano (Archer, 2013b; Porpora, 2013). La primera se refiere al nivel en que tienen lugar las relaciones entre las posiciones sociales de un momento histórico y se vincula con la crítica social según se generan tensiones en estas relaciones que se convierten en objetos de crítica. Así, por ejemplo, las desigualdades económicas o culturales producto de diferentes posiciones sociales se sitúan en la estructura y pueden devenir en objetos de denuncia. Luego, estos objetos de crítica son abordados de manera particular por los agentes según una cultura ${ }^{7}$, es decir, a través de un marco reflexionado por el agente que consiste, por tanto, en el procesamiento subjetivo de las relaciones entre las posiciones sociales que daban lugar a la estructura. Siguiendo los términos de Boltanski, podemos decir, entonces, que el objeto de la crítica se encuentra en el mundo, que es "todo lo que acontece" (2012, p. 68). En otras palabras, el objeto tomado por la crítica proviene de la existencia objetiva de las cosas y las relaciones entre estas, tales como la posición económicamente privilegiada de una élite o las diferencias en las remuneraciones de hombres y mujeres. Por otra parte, el marco de referencia con que este objeto es juzgado pertenece a la realidad, en tanto construcción social en el sentido de Berger y Luckmann (1996). La realidad se refiere a aquello que es percibido con cierto orden y coherencia, haciéndole sentido a los agentes. En esta dirección, es en la realidad -como el

\footnotetext{
${ }^{7}$ La noción de cultura para Archer (1996) corresponde a un ámbito de la realidad social que da consistencia al sistema social, así como cohesiona a los grupos de actores sociales. De esto se desprende que está compuesta por dos aspectos que juegan papeles relacionados, aunque distintos. En un afán por evitar que todo lo que no es individual se considere como perteneciente a la cultura, Archer deslinda la integración del sistema cultural (Cultural System integration) de la integración socio-cultural (Socio-Cultural integration). La primera se refiere a las relaciones entre los componentes de la cultura, mientras que la segunda se refiere a las relaciones entre los agentes culturales. A través de la integración del sistema cultural se establece el grado de consistencia provisto por la cultura al sistema social. En este ámbito se encuentra el corpus de las cosas que pueden ser interpretadas o conocidas por alguien (intelligibilia), a partir de las que se producen proposiciones lógicas. La integración socio-cultural da cuenta de la extensión de la cohesión entre los grupos de actores sociales. Por tanto, se refiere a las redes de relaciones en las que cada individuo se encuentra inmerso desde contextos geográficos, familiares e institucionales. En este último ámbito se sitúa lo simbólico.
} 
lugar percibido donde se encuentra y construye sentido y orden-, donde se alojan los principios de justicia que (des)legitiman fenómenos como una posición económicamente privilegiada.

Finalmente, la realización de los juicios críticos tiene un vínculo estrecho con la agencia, en tanto es un agente quien los activa en la realidad social. Es el agente quien realiza los juicios críticos de una forma determinada en la praxis social. Esta última es relevante ya que, según Öztürk interpreta a Bourdieu, es un plano que excede la mera acción social:

De acuerdo a Bourdieu, la praxis es más que la acción social que se observa en un evento aislado. La praxis es una actividad en la que individuos humanos producen y reproducen la sociedad en sus dimensiones cultural, social y económica. Posee un rol que media entre la acción social individual y el desarrollo societal. (2011, p. 250 traducción propia)

Estas relaciones entre crítica social, juicios críticos y sus componentes de trasfondo se representan en la figura 4.1, teniendo como referencia final los efectos prácticos o resultados (outcome) asociados a la crítica.

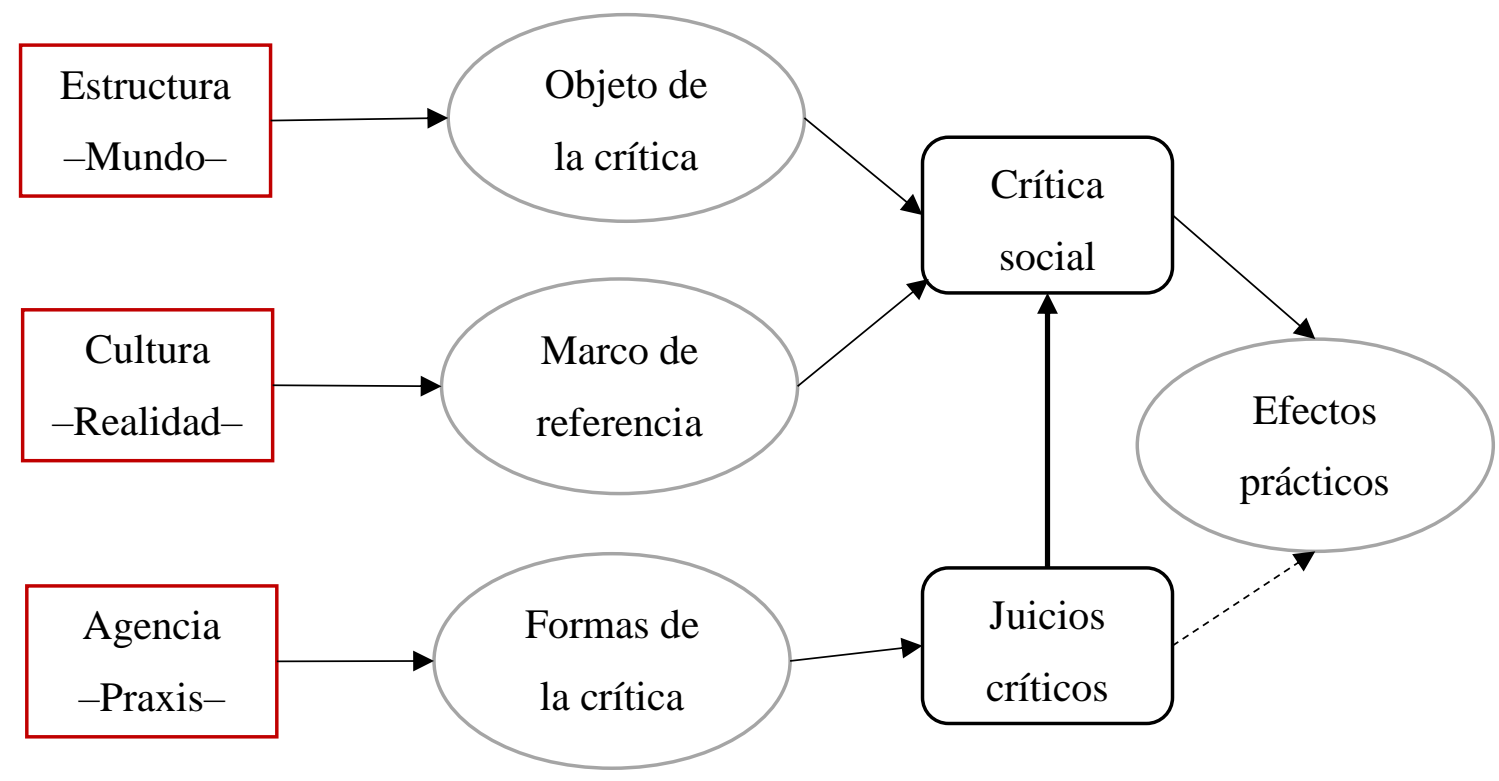

Figura 4.1 Esquema de las relaciones entre crítica social y juicios críticos. Fuente: Elaboración propia.

Entre las distinciones que realizan Boltanski y Chiapello (2007) respecto a la crítica social, cabe destacar la que hacen entre una crítica radical y otra reformista. Esta última toma un 
carácter correctivo respecto a la realidad que critica, a diferencia de la radical o revolucionaria, que busca transformarla. Sucintamente, Boltanski las caracteriza así:

La crítica reformista no cuestiona el marco de la realidad en su totalidad [...] Esa crítica conduce a modificar algunos de los formatos sin tocar el conjunto. La crítica radical, en cambio, para decirlo en pocas palabras, cuestiona la realidad de la realidad. Extrae del mundo elementos que permitan deconstruir las convenciones admitidas hasta ese momento y, con esto, desestabilizar la realidad en su conjunto. (2012, p. 68).

Entonces, es posible realizar una distinción gruesa entre una crítica que se despliega en los marcos de una realidad y otra que, precisamente, es disruptiva del orden particular donde tuvo lugar.

Además, la crítica puede distinguirse según los niveles de reflexividad en que tiene lugar. En términos generales, se marca una diferencia entre momentos prácticos de baja reflexividad de los agentes, que desfavorecen el surgimiento de la crítica o alojan una crítica reformista, y otros momentos metapragmáticos, marcados por un alto nivel de reflexividad, donde se cuestionan las reglas mismas de la realidad (Boltanski, 2011). Se habla de un momento metapragmático en el sentido de que no estarían reducidos solo a la praxis. Tales momentos, por ejemplo, son los que supone la elaboración teórica. Cuando un sociólogo, como Parsons (1968), se proponer explicar la estructura de la acción social a partir de un esquema analítico abstracto y general, está cuestionándose y sistematizando las relaciones sociales que ocurren en la praxis. Por lo tanto, se trata de un momento metapragmático en la medida que problematiza la propia praxis, abstrayéndose de esta. Esta noción de reflexividad se esclarece con la definición que da Archer de la misma: "[la reflexividad es] el ejercicio regular de la habilidad mental, compartida por todas las personas normales, de considerarse a sí mismos en relación a sus contextos (sociales) y viceversa" (Archer, 2012, p. 1 traducción propia), que toma la forma de una conversación interna (internal conversation). La reflexividad, entonces, se ilustra como un proceso interno de preguntas y respuestas posibilitado por la capacidad que poseemos los humanos de usar el lenguaje para hablar con nosotros mismos (Archer, 2007). En tal sentido, para Boltanski, los momentos de alta reflexividad son aquellos en los que "la atención de los participantes se traslada de la tarea que se realizará a la pregunta 
por cómo es apropiado caracterizar lo que está sucediendo” (2011, p. 67 traducción y cursiva propia).

Por último, siguiendo el desarrollo que realiza Honneth (1996) sobre los sentimientos de injusticia y las experiencias de sufrimiento moral, existen distintos niveles de la realidad en los que los juicios críticos se cristalizan. Se encuentra el nivel del sentimiento de injusticia individual, donde la enunciación de juicios críticos puede entenderse como situada en la conversación interna antes mencionada. Luego, en la medida que estos son exteriorizados, surge el nivel colectivo donde se realizan los juicios críticos, a través de interacciones entre un alter y un ego. En la medida en que los juicios críticos alcanzan una mayor visibilidad y son legitimados, se sitúan en el nivel de la denuncia pública, eventualmente formando parte de acciones colectivas concertadas, por ejemplo a través de movimientos sociales. En este esquema, un juicio crítico a nivel individual puede pasar a ser colectivo o público al ir pasando ciertas pruebas de legitimidad y generalización de su marco de referencia (Basaure, 2011). Se puede ilustrar este proceso con el caso del sufrimiento moral por una carencia de reconocimiento expuesto por Honneth. Así, en un principio, los individuos sienten que no son reconocidos en su identidad social, de manera que sus particularidades o aspectos culturales no son atendidos intersubjetivamente, por lo que viven situaciones de sufrimiento moral que perciben de manera individual. Después, los sujetos identifican lo colectivo de ese sufrimiento, según se visibilizan las situaciones que han llevado a esa experiencia y se tematizan en la vida social. Finalmente, las experiencias colectivas de los sujetos han de traspasar la mera tematización y se expresan en la esfera pública, eventualmente articulándose en una acción colectiva, ya sea como movimientos sociales o a través de canales político-formales. De estas fases se desprende, por un lado, cómo en términos macro se relaciona la percepción de injusticias y su crítica con la reproducción y el cambio social, mientras que, por otro lado, se vuelve a enfatizar la dimensión colectiva en que la crítica es generada y opera.

\subsection{El rol de la crítica frente al problema de la reproducción y la transformación social}

La realidad social tiene un sustrato eminentemente histórico en dos sentidos, en tanto es el producto de la historia, así como es la base sobre la que esta se proyecta, al considerar un horizonte de futuro. En esta dimensión histórica, se pueden distinguir dos grandes procesos, 
según una trayectoria histórica exhiba constantes o rupturas. En la medida en que prevalecen las constantes, se suele hablar de una reproducción social, mientras que cuando destacan los quiebres se reconocen procesos de transformación social. Sin lugar a dudas, siempre conviven cambios y rupturas, lo que implica que el orden social está cruzado por procesos de morfogénesis y morfostasis social, en el sentido en que Margaret Archer y sus colaboradores los definen desde el enfoque M/M (Archer, 2013a, 2014). Esto es, como procesos que tienden a elaborar o cambiar la forma de un sistema, en el primer caso, o como uno que tiende a conservarlo, en el segundo. Por ejemplo, mientras los regímenes monárquicos en América Latina daban paso a procesos de independencia en el siglo XIX, la relegación de las mujeres a los espacios privados se mantenía sin mayores cambios hasta entrado el siglo XX. Asimismo, el carácter rural de la población continuaría determinando las formas de vida de la misma hasta la segunda mitad del siglo XX. ¿Cuál de estos fenómenos es más decisivo para definir si se trata de un proceso de cambio o de continuidad? Dependerá del enfoque, pues precisamente, según Archer (2013a), uno de los obstáculos al estudiar el cambio social reside en la carga valórica (value-laden) y teórica que el investigador necesariamente asume al seleccionar uno o varios de estos fenómenos. De todas formas, la preeminencia de rupturas o de continuidades es algo que se juega en el mismo despliegue de la realidad social, dependiendo de la particular interacción que existe entre la estructura, la agencia y la cultura (Archer, 2013a, 2013b). Por lo demás, cabe destacar que los cambios pueden ser necesarios para la mantención de un sistema social, por lo que no sólo deben identificarse como morfogénesis. De ahí que sea importante la definición de qué cambios deben ser considerados.

Lo que interesa aquí es que las rupturas y las continuidades se vinculan con la crítica a partir de la agencia que esta última supone. Al manifestarse en la praxis, la crítica provoca ciertos efectos en la misma. Tales efectos son los puntos de evaluación respecto a lo que cambia o se mantiene desde la crítica. De esta manera, la crítica social se propone como un mecanismo generativo tanto de procesos morfostáticos como morfogenéticos. Independiente del alcance de los resultados que la activación de la crítica tenga, en términos generales se trata de cómo la enunciación de juicios críticos tiene efectos en otros agentes y, desde ahí, en la realidad social. A modo de ilustración, puede figurarse un trabajador que presta servicios a una empresa contratista externa para otra empresa, cumpliendo las mismas labores que otros 
trabajadores contratados directamente, pero recibiendo un salario menor al de estos últimos. Eventualmente, luego de conocer este hecho el trabajador tercerizado puede experimentar un sentimiento de injusticia ("¿por qué alguien que hace el mismo trabajo que yo recibe un sueldo mayor?'). En la cotidianeidad de los intercambios con sus colegas, puede enunciarse este sentimiento como un juicio crítico, por un lado dando a conocer esta realidad a quienes no estaban al tanto, así como generando una posición y diálogo al respecto. Un efecto posible sería que, si se comparte un marco de referencia donde la desigualdad salarial frente a las mismas tareas desempeñadas es injusta, se constituya una posición generalizada de apoyo. Aquello puede escalar a una acción a nivel de sindicatos y federaciones, a su vez generando mayores espacios de reflexividad que desenmascaren otras injusticias en este ámbito. Por supuesto que no se trata de un modelo así de lineal, simple y ordenado en la realidad, pero este ejemplo permite ver cómo surgen efectos de la crítica en distintos niveles que facilitan u obstaculizan cambios y reproducciones del estado de las cosas. En este caso, si los colegas contratados directamente consideraran que la brecha salarial es justa, podrían enarbolar otros juicios críticos de vuelta, como que el estar directamente contratados responde a la confianza que la empresa deposita en ellos. En este caso hipotético, los juicios críticos tendrían efectos de reproducción de la desigualdad salarial, desde el punto de vista de la distribución de los salarios y su justificación.

Ya que la realidad social comprende una dimensión proyectiva, pues siempre existe un horizonte esperado o deseado del desarrollo del presente, es que la crítica puede tener lugar, pues es tributaria de la capacidad humana de figurar una realidad otra y de elaborar justificaciones sobre lo que existe y lo que puede existir, es decir, de reflexionar (Archer, 2013a). Es gracias a esta capacidad reflexiva que también se pueden interpretar experiencias pasadas de manera distinta a cómo un mismo actor o las instituciones sociales lo habían hecho en el pasado (Koselleck, 2004). Por lo mismo, ciertas situaciones que han sido percibidas como normales por largo tiempo tienen el potencial de ser reinterpretadas como injustas en otro momento. Como proceso reflexivo, la crítica social puede operar en la transición que lleva a un proceso de elaboración cultural o estructural. Este proceso puede generar una transformación que da pie a la morfogénesis social (Porpora, 2013). En contraste, al derivar en un efecto que refuerza el orden de las cosas en la realidad, la crítica mediaría a favor de la morfostasis social. De esta manera, la definición de morfogénesis o morfostasis social en 
relación a la crítica se realiza evaluando cuáles son los efectos que tiene esta última en la realidad, así como considerando el punto de vista de quien evalúa el carácter del efecto operado por la crítica. En el ejemplo del trabajador tercerizado es posible advertir un efecto del juicio crítico emitido por el trabajador subcontratado cuando comparte su situación con sus colegas. Luego, si desde la posición del analista se considera una perspectiva que tiene a las desigualdades económicas como punto de evaluación relevante para el cambio social, se consideraría como un efecto que apunta a un proceso de morfogénesis o morfostasis social según sea el resultado de los efectos de la crítica enunciada.

Existen juicios críticos que se manifiestan frente a los diversos tipos de desigualdades que se presentan en la sociedad, lo que analíticamente se puede sistematizar como una crítica social a las desigualdades que tiene por objeto la distribución de recursos de distinto tipo (ingresos, credenciales educativas, salud, vivienda, prestigio) y los criterios bajo los que esta distribución se ha concretizado (Barozet \& Mac-Clure, 2015; Boltanski, 2011). La crítica social, entonces, es un constructo que se sitúa en un nivel meso social, pues no se trata del juicio crítico aislado que profiere un individuo, ni es algo que está engarzado sólo en la estructura o la cultura. Como una operación que tiene lugar en un espacio intermedio, la crítica social es un componente relevante dentro de la (re)producción de la realidad social, en la que intervienen factores relativos a la estructura, la agencia y la cultura. Es por esto que el vínculo estrecho que guarda la crítica tanto con la reproducción como con la transformación de la realidad social debe considerar elementos de estos tres componentes sociales para ser comprendido.

Para precisar la relación entre la crítica social y sus implicancias en la realidad -sea como un aliciente de la transformación o de la reproducción social u otro eventual efecto- se debe atender al carácter particular de esta en su contex to de realización, es decir, en su dimensión pragmática (Basaure, 2011). En el caso de la crítica a la desigualdad, del tipo que sea esta última, se ha de identificar el marco normativo o de referencia en base al que se juzga, que corresponde a los principios de justicia que emergen en la interacción social y que, como mencionamos, responden principalmente a un factor cultural. Los principios de justicia se enmarcan en concepciones de justicia social, donde esta última corresponde a un ámbito de discusión sobre "cómo las cosas buenas y malas deben ser distribuidas entre los miembros 
de una sociedad humana" (Miller, 1999, p. 1 traducción propia). Para reconocer estos principios de justicia es pertinente atender los distintos tipos de juicios de justicia social identificables: juicios de justicia y actitudes hacia la justicia (Liebig, 2001). Para Liebig, los juicios de justicia se realizan desde un punto de vista imparcial y se basan en principios morales que apelan a ser universales. En cambio, las actitudes hacia la justicia, la otra clase de juicios de justicia social, están mayormente guiadas por las preferencias personales de quienes los emiten y se caracterizan por tomar principios que consideran la parcialidad del punto de vista de los actores.

Son estos últimos juicios de justicia los que suelen tomar forma en los actores ordinarios, por ejemplo cuando se manifiesta como una situación injusta la desigualdad salarial frente a las mismas tareas desempeñadas, en el caso del trabajador tercerizado utilizado más arriba. Aquello se relaciona con la reflexividad con que abordan las situaciones susceptibles de crítica los actores ordinarios frente a otros expertos, pues es mayor la reflexividad de los intelectuales al elaborar una crítica experta frente a la de un trabajador que reflexiona en los marcos permitidos por su cotdianeidad. En este punto se releva la praxis involucrada en el proceso de construcción del marco de referencia: "La visión subjetiva de lo justo se construye pragmáticamente, con una mezcla de principios generales y de confrontaciones a situaciones específicas en la vida cotidiana" (Barozet \& Mac-Clure, 2015, p. 10). Dentro de los juicios de justicia, son de especial interés los que se refieren a la justicia distributiva (Zelditch, Berger, Anderson, \& Cohen, 1972), es decir, los que refieren a los criterios que subyacen a una repartición (in)justa de los distintos bienes - materiales y simbólicos-, ya que se relacionan con la crítica a las desigualdades.

Finalmente, cabe destacar la propuesta hecha por Schwalbe y colegas (2000) sobre la existencia de cuatro procesos genéricos de reproducción de la desigualdad en las interacciones. La alterización (othering) es un proceso a través del que un grupo dominante define a otro grupo como inferior, utilizando ciertas marcas o características distintivas. La adaptación subordinada (subordinate adaptation) apunta a los procesos en los que los subordinados reproducen desigualdades al adaptarse al contexto que los subordina, por ejemplo, al verse obligados a aceptar comportamientos que van en su contra o degradan su posición. El mantenimiento de fronteras (boundary maintenance) se refiere al sostenimiento 
de fronteras entre los dominantes y los grupos subordinados con el objetivo de preservar la posición dominante, ya sea en términos simbólicos, espaciales o bien en las interacciones. Consiste en la creación de cierres sociales, generalmente a través de instituciones como la escuela o el gobierno, para limitar que individuos de otros grupos compartan algún bien o relación social preciada, como el capital cultural o el acceso a redes sociales. Por último, la administración de emociones (emotions management) apunta a controlar emociones negativas hacia el statu quo o positivas hacia los oprimidos, para evitar la desestabilización del orden que podría surgir producto de percepciones de injusticia sobre este. Las interacciones que aparecen en el intercambio de juicios críticos permiten evaluar si algunos de estos procesos se observan y en qué sentido reproducen las desigualdades en el discurso de los participantes.

\subsection{El enfoque de análisis morfogenético y pragmático}

En la línea del enfoque desarrollado por Margaret Archer (Archer, 2013a, 2013b, 2014), llamado M/M (morfogénesis/morfostasis) o enfoque morfogenético, planteamos que el estudio de la crítica social debe fundarse en una interacción entre tres planos analíticamente distintos de la realidad social: la estructura, la agencia y la cultura, donde la estructura refiere a las posiciones sociales de un momento histórico y espacial dado, la cultura, por su parte, se trata de un marco reflexionado que consiste en el procesamiento subjetivo de las relaciones entre las posiciones sociales que dan lugar a la estructura y la agencia es el nivel en que se despliega la acción. Sostener esta distinción analítica implica evitar la falacia de la conflación, es decir, el que alguno de estos elementos sea subsumido en los otros: que la agencia, por ejemplo, no sea subsumida en la cultura o la estructura, o la estructura en la cultura o la agencia, lo mismo con la cultura. Esto se traduce en que ninguno de los tres elementos sea considerado como un epifenómeno de los otros. Se busca tener en consideración la eficacia causal propia de todos estos planos que componen la realidad social, abordando las relaciones que guardan entre sí. De tal manera, la morfogénesis evita una visión de la sociedad y de cómo esta se mantiene, reproduce o transforma de abajo hacia arriba (bottom-up) o de arriba hacia abajo (top-down) (Forbes-Pitt, 2013).

Dentro de la teoría social se puede apreciar una constante tensión entre enfoques que sobreponen los factores estructurales en su explicación de la sociedad, sostenidos por autores 
como Emile Durkheim (1989) o Talcott Parsons (2012), frente a otros que centran su explicación en el rol de la acción individual, donde destacan autores como Max Weber (2008). Archer (2013b) denomina a los primeros conflacionismo descendente y a los segundos conflacionismo ascendente. Además, según la socióloga inglesa, existe una tercera posición en la que se confunden las propiedades de la cultura y la estructura con las de la agencia, sin atender las propiedades particulares de cada una. Esta posición se denomina conflacionismo central o elisionismo. Buena parte de la discusión teórica en la sociología contemporánea tiene lugar a partir de autores que para Archer se encuentran en esta línea, como Anthony Giddens (1995) y Pierre Bourdieu (2012). El enfoque M/M, en este sentido, implica que:

En suma, el enfoque morfogenético supera completamente la oposición total entre el individualismo metodológico y el holismo sociológico. En contraste con el individualismo metodológico, la gente no actúa aparte o fuera de contextos culturales y sociales estructurales, y, en contraste con el holismo sociológico, el foco causal está en la gente individual inserta en un entramado de relaciones humanas. (Porpora, 2013, p. 29 traducción propia).

A través de esta perspectiva, es posible posicionar la pregunta por la crítica social como un mecanismo generativo tanto de procesos morfostáticos como morfogenéticos, ya que lleva a considerar el rol que tiene la agencia en los cambios y continuidades de la realidad social, considerando a su vez a la estructura y la cultura como parte del contexto donde estos tienen lugar. Esto significa que, por ejemplo, no puede suponerse que la reproducción de las desigualdades se configura sólo a través de ciertos efectos culturales o estructurales, como una sociedad de castas o una ley económica que determinen exclusivamente la relación en que los bienes económicos son distribuidos. En tal caso, los agentes serían un epifenómeno de estos efectos y no se tomaría en consideración el papel activo de ellos que contribuye a que se reproduzcan las desigualdades. Así, cuando Boltanski se interroga en términos de “¿por qué los explotados aceptan una situación que se encuentra en patente contradicción con las exigencias de libertad e igualdad sostenidas en los regímenes políticos que reivindican la herencia de la Revolución Francesa?” (Boltanski, 2012, pp. 67-68), propone que sería precisamente por un sentido realista de los actores, relevando entonces el factor agencial: 
“[Los explotados] autolimitan sus reivindicaciones en función de su apreciación sobre las posibilidades que estas tienen de ser reconocidas y, por lo tanto, de ser más o menos satisfechas en la realidad" (Boltanski, 2012, pp. 67-68). Aquello, cabe destacar, se encuentra en la línea de los resultados de Juan Carlos Castillo (2011) para el caso chileno, según los que es el contexto de alta desigualdad económica el factor clave en la legitimación de esta desigualdad, es decir, para las personas lo que es se constituye como el referente principal de lo que debería ser.

Al considerar el rol agencial de la crítica social, no sólo se le abre paso al enfoque M/M, sino que se posibilita el considerar la contribución de esta tanto a procesos de morfogénesis como de morfostasis. La morfogénesis se trata de los procesos que tienden a elaborar o cambiar la forma de un sistema, mientras que la morfostasis se trata de un proceso que tiende a conservarlo, reproduciendo la realidad. Ninguno de estos dos procesos tiene una preeminencia de antemano en una formación social, sino que su presencia relativa varía según la situación histórica. Por lo demás, para que la morfostasis se realice no tiene que seguir todo igual, sino que se permiten cambios que, de hecho, mantengan al sistema, según este sostenga un proceso adaptativo. Tal como no toda crítica es radical, los cambios tampoco apuntan necesariamente a transformar la realidad. Siguiendo el esquema de los procesos $\mathrm{M} / \mathrm{M}$, que se componen de cuatro momentos ( $\mathrm{T}$ ), se puede apreciar en la figura 2 y 3 que la fase de mantenimiento (maintenance) o elaboración (elaboration) viene de un momento previo de interacción, donde necesariamente entra en juego la agencia. 


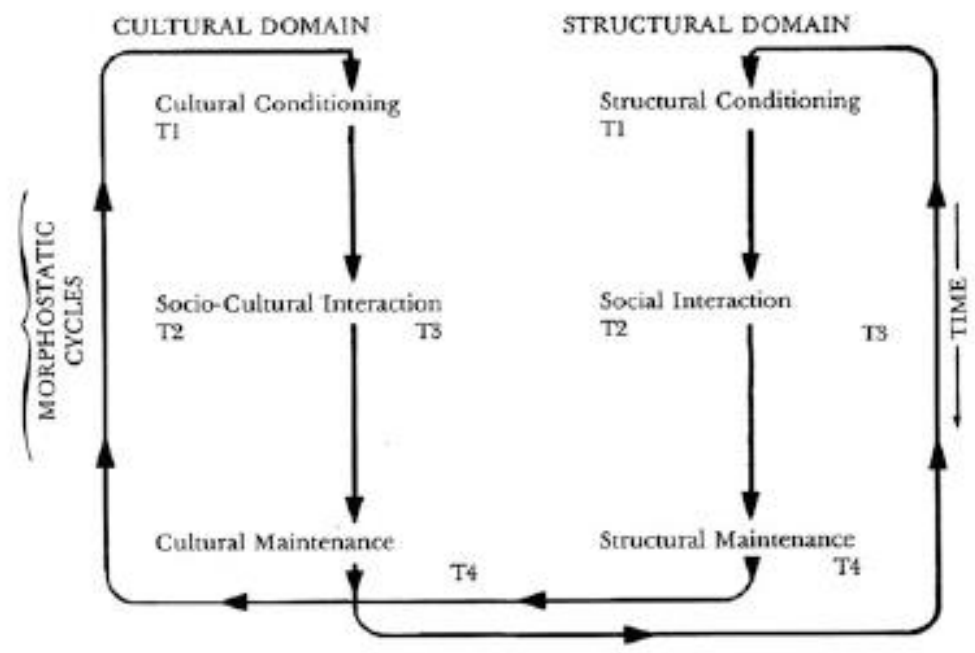

Figura 4.1 Morfostasis social. Fuente: (Archer, 2013a, p. 7)

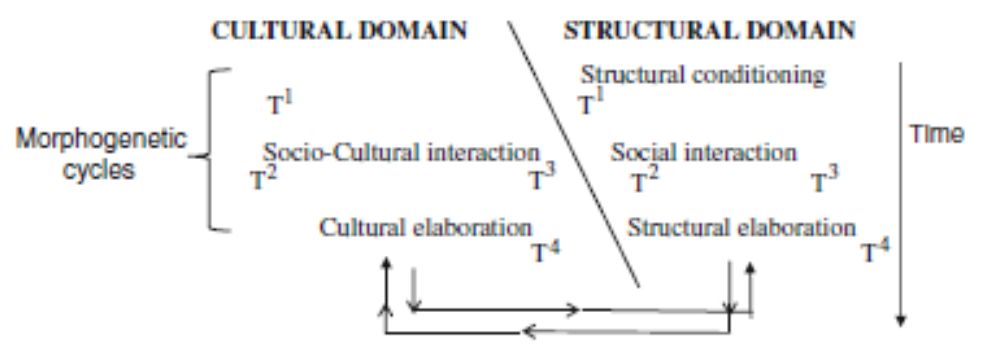

Figura 4.2 Morfogénesis social. Fuente: (Archer, 2013a, p. 7)

Tal como Archer (2014) resalta que en la modernidad tardía, que corresponde al período actual, parece destacarse un incremento de los cambios en la sociedad, Boltanski señala respecto a la sociedad capitalista-democrática que "una de sus características es garantizar una forma de dominación que se basa en la insistencia puesta en el cambio" (2012, p. 73). Aquello se traduce en la posibilidad lógica y teórica de que los cambios estén al servicio de mantener un orden particular y, por lo mismo, de que la crítica social sirva a este mismo fin. De hecho, el capitalismo tendría una habilidad para asimilar la crítica, en tanto "no hay ninguna ideología, por muy radicales que sean sus principios y formulaciones, que eventualmente no se haya mostrado abierta a la asimilación” (Boltanski \& Chiapello, 2007, p. Xv traducción propia). En esta misma dirección, ya autores como Adorno y Horkheimer (2007) han dado cuenta de la alta capacidad que posee la modernidad de asimilar distintas corrientes e ideologías. En definitiva, aunque los procesos de crítica social marquen una 
diferencia entre la realidad constatada y un marco de referencia que difiere de esta, nada asegura que tal diferencia tenga la fuerza suficiente para implicar un cambio de la sociedad desde la perspectiva de un punto de evaluación sustantivo. El sistema capitalista, como modo de producción no sólo de bienes materiales y servicios, sino también como un modo de producción de lo social (Boltanski \& Chiapello, 2007), puede ser considerado como un punto de evaluación sustantivo. Por lo mismo, Boltanski no pasa por alto el que las críticas al capitalismo son tan antiguas como este mismo y que los dispositivos de dominación, aquellos “asociados a la mantención duradera de una o de más asimetrías profundas” (2012, p. 73), absorben fácilmente a la crítica. En definitiva, para el discípulo de Bourdieu:

Este modo de dominar la crítica, incorporándola, se ve reforzado por el hecho de que la dominación por el cambio se vale ella misma de la crítica. La crítica es así un momento de la propia dominación y se le priva a quienes quisieran oponerse a esta. (2012, p. 82)

En suma, tal como se le concede un alto potencial transformador a la crítica, también se le otorga una fuerte potencia a la hora de reproducir el orden de las cosas en un punto de evaluación general, como es el capitalismo.

\subsection{De la crítica experta a la crítica ordinaria}

Uno de los obstáculos para dar cuenta de la crítica social destacados por Boltanski (2011) consiste en la fijación que durante la mayor parte del siglo XX hubo en la crítica experta, llevada a cabo por intelectuales y académicos, en detrimento de un análisis pragmático de los juicios críticos cotidianos. Aquello está en sintonía con un largo desarrollo histórico en Occidente, donde la filosofía privilegia la elaboración de un pensamiento autónomo que supere una visión parcial basada en el conocimiento que proveen los sentidos ${ }^{8}$, así como la razón crítica se incorpora como un elemento central y superior en el desarrollo del estado moderno, definiendo su configuración (Koselleck, 1998). Es así como toman un lugar privilegiado las posiciones metacríticas, que son para Boltanski (2011) aquellas que consisten en una crítica sistemática de un orden social particular, que tienen como base una descripción científica sociológica o antropológica. Se trata de las construcciones teóricas que apuntan a “desenmascarar, en sus dimensiones más generales, la opresión, la explotación o la

\footnotetext{
${ }^{8} \mathrm{Al}$ respecto, es ilustrativo que uno de los hitos fundantes de la filosofía moderna se reconozca en la idea cartesiana de desarrollar un ejercicio analítico que no dependa de lo sensorial.
} 
dominación, en la forma que sea que ocurran” (Boltanski, 2011, p. 6 traducción propia), con un horizonte de emancipación.

Frente a este obstáculo en particular, Bolstanski plantea la posibilidad de relevar la dimensión pragmática de los juicios críticos, en la línea de lo que autores como Habermas (2010), en la teoría social, y Austin (1975), en la linguiística, realizaron décadas antes. A partir de las posiciones metacríticas desarrolladas por las vertientes críticas de algunas disciplinas, como es el caso de Bourdieu en la sociología, Boltanski señala que la crítica ordinaria aparece como un complemento necesario. De hecho, uno de los aspectos que marca la distancia que toma Boltanski con Pierre Bourdieu, con quien colaboró estrechamente, reside en este giro pragmático (Guerrero \& Ramírez, 2011). La crítica ordinaria corresponde a la que realizan los actores involucrados en disputas cotidianas, dentro de ciertas secuencias de crítica y justificación con diversos niveles de generalidad (Boltanski, 2011). Existe una interdependencia de las posiciones metacríticas con la crítica ordinaria: "las teorías metacríticas no pueden ignorar las insatisfacciones expresadas por los actores y su objetivo último es reenfocarlas de manera de darles una forma robusta; mientras que los actores usualmente acuden a las teorías metacríticas para buscar recursos que alimenten sus injusticias" (Boltanski, 2011, p. 61 traducción propia); es en este sentido que se deben desarrollar conjuntamente.

En el fondo, al situar a la crítica social como la unidad de análisis, a través del estudio de la pragmática del juicio, vale decir, a partir de la dimensión práctico-discursiva en que los juicios son enunciados, entran en juego las variadas significaciones de la justicia de los actores en situaciones específicas (Boltanski \& Thévenot, 2006). Es en este punto donde nos interesa analizar cómo se despliegan estas significaciones en un contexto de interacción como el presentado por los juegos experimentales utilizados en este caso.

\subsection{La crítica social en su dimensión pragmática}

Como se ha expuesto, las condiciones de realización de los juicios críticos son un aspecto importante para el análisis de la crítica social, en la medida que contribuyen a definirla. Esas condiciones consideran factores estructurales y culturales, donde destaca el contexto político y económico, así como aspectos más específicos vinculados a los agentes que enuncian los juicios críticos, tales como la clase social a la que pertenecen, el territorio y el barrio donde 
residen, su nivel educacional, entre varios otros. La relevancia de la dimensión pragmática, así, consiste en evaluar adecuadamente cómo este tipo de factores influye en los juicios críticos, dando paso a una crítica social determinada.

Con un afán organizador, diferenciamos a los juicios interpretativos sobre el mundo social es decir, aquellos que hacen una evaluación subjetiva sobre este-, según el lugar que toman en la praxis, acorde al esquema de Boltanski (2011). El sociólogo francés sostiene que estos juicios interpretativos que expresan los actores sociales son parte de una disputa situada en la realidad social y que, según cómo se pruebe su validez, ya sea reafirmando la justificación del orden social o criticándolo, pueden surgir tres tipos alternativos de juicios: juicios de verdad, de realidad y existenciales.

El juicio de verdad juega un rol importante en la reproducción de la realidad. En él no interesa la realidad de la realidad, pues crea un efecto de suficiencia y coherencia frente a una realidad dada. Para su realización destacan las repeticiones como una prueba fehaciente y visible de que la realidad factual se ha basado tradicionalmente en una misma norma. Así, por ejemplo, se observa cómo ciertas ceremonias oficiales, religiosas y familiares, refuerzan la realidad percibida, como en el caso de los premios académicos que entregan las distintas instituciones educativas, donde se busca reafirmar que haber conseguido ciertas calificaciones constituye efectivamente un logro importante que, además, es individual; aquello además sin miras a si acaso el galardonado consiguió las calificaciones necesarias de manera honesta o si hizo trampa. Mientras sean aceptados y no se pongan en cuestión, los juicios de verdad refuerzan el carácter de la realidad en que son realizados. No obstante, pese a su capacidad de generar empatía incluso respecto a la realidad construida, este mecanismo puede ser inducido a fallas, dejando de reforzarla. A modo de ilustración, se puede considerar los juicios de verdad como enunciados cuasi-tautológicos, en tanto se valen de la repetición para mantener la validez de ciertas normas convencionales -y no racionalmente fundadas-: "Dios es dios", "El rey es el monarca", "La república es la república” (Boltanski, 2011, p. 104). La puesta en cuestión de estos objetos - dios, el rey o la república-, contribuye a interrumpir la empatía dispuesta hacia el estado de las cosas en la realidad.

Por su parte, los juicios de realidad se emplean para enfrentar la crítica a una situación de disputa. Estos juicios buscan establecer si lo normativo -lo que debería ser según el marco 
de referencia particular del actor- tiene un correlato con la realidad -vale decir, con lo que es-, así como evalúa si acaso lo que ocurre posee una validez general o se encuentra cruzado por intereses creados de un actor o un conjunto de estos. En otras palabras, los juicios de realidad apuntan a evaluar si lo que se observa en la realidad se ajusta a las normas que fundamentan esa misma realidad. Por tanto, se encuentran integrados por dos aspectos: por una parte, un criterio acerca de cómo se debe valorar la realidad - un estándar evaluativo- y la aplicación de esto a una valoración respecto de una situación real -cómo se perciben las cosas en realidad-. En definitiva, para Boltanski los juicios de realidad están al servicio de una crítica reformista, ya que se mueven dentro del mismo marco de referencia predominante en la realidad, apuntando a aspectos correctivos acordes a este marco. Los juicios de realidad, por ejemplo, pueden apuntar al modo ilegítimo en que una prueba se aplica, ya sea porque un grupo de personas obtiene un mayor puntaje en un examen escolar estandarizado por sus recursos económicos y no sólo por su conocimiento sobre los contenidos, o a los resultados de una elección que ha sido llevada adelante con un proceso fraudulento. En este caso, puede surgir una crítica a través de un incremento de la reflexividad que lleva a los actores a repensar la interpretación de la realidad.

Por último, los juicios existenciales se basan en las experiencias personales calificadas como subjetivas, sean las experimentadas por uno mismo o las que han sido vividas por cercanos que pueden ser apropiadas. En el caso de la crítica, se extraen ejemplos -o bien contraejemplos- que invalidan las pruebas establecidas en las reglas de justificación. Es decir, en base a lo vivido subjetivamente se contradicen criterios que aparecen en la realidad. Por ejemplo, si existe el criterio de que para conseguir altos ingresos se necesita un gran esfuerzo en la vida laboral, quienes se reconozcan como poseedores de una trayectoria laboral de esfuerzo, no obstante sin las remuneraciones asociadas, emitirían un juicio existencial al evidenciar este desfase.

Estas distinciones en los juicios permiten diferenciar en la realización pragmática de los mismos aspectos relevantes para la crítica social, como la relación entre las enunciaciones y sus marcos de referencia normativos. El que un juicio crítico pueda identificarse con alguno de estos tipos de juicios supone el esclarecimiento de la relación que estos guardan con su 
contexto pragmático. En este sentido, es necesario tener en cuenta la dimensión pragmática de la crítica social para una comprensión de la misma.

En suma, es evidente que la crítica se expresa discursivamente, en tanto considera la materialización comunicativa de un sentimiento o percepción de injusticia que atraviesa un tamiz de principios de justicia en su expresión. De esto se desprende además que la crítica no genera automáticamente una acción, pues su fuerza ilocutiva, aquella que se refiere a sus efectos en la realidad, no viene asegurada. Por lo demás, existe una relación estrecha, aunque no idéntica, entre lo que la crítica expresa en su contenido y la forma en que lo hace. Dependiendo del contexto, por ejemplo, una crítica que cuestiona un mismo aspecto de la realidad puede ser enunciada con un tono de evidente denuncia y hastío o de manera subrepticia y esquiva. Es en este sentido en el que destaca la dimensión pragmáticodiscursiva que la caracteriza. En definitiva, la crítica se enuncia como una inquietud o como una denuncia, donde el emisor efectúa un cuestionamiento o una transgresión a una norma (Boltanski, 2011).

\subsection{El rol del cuerpo en los juicios críticos}

La relevancia del cuerpo como un componente de la realidad social ha sido destacada en distintas líneas de la sociología. Para Bourdieu (2007), el habitus es un principio explicativo del mundo social y corresponde a un conjunto de disposiciones sociales que son incorporadas y desplegadas, en parte, a través de los cuerpos. Por lo tanto, la producción y reproducción de lo social implica la corporalidad que opera como expresión de un "subjetivismo colectivista", según el que "la singularidad del «yo» se forja en las relaciones sociales y por medio de ellas" (Bourdieu, 1999, p. 178). En otras palabras, el cuerpo es un componente del espacio social que tiene efectos sobre él y que, a su vez, interioriza elementos del mismo.

Por su parte, Goffman (Goffman, 1966, 1997, 2001) puso especial atención al rol del cuerpo en la interacción social, dándole relevancia teórica en la explicación de lo social. Para el sociólogo estadounidense, la interacción social cara a cara constituye un fundamento de la realidad social que puede ser entendido desde el enfoque dramatúrgico que propone, según el cual los individuos buscan significar hacia otros con sus acciones. Este proceso de significar se realiza a través de la realización dramática, donde es relevante, por ejemplo, el mantenimiento del control expresivo, dado que: 
[...] un actuante puede transmitir de manera accidental incapacidad, incorrección o falta de respeto al perder momentáneamente control muscular de sí mismo. Puede resbalar, tropezar, caerse; puede eructar, bostezar, cometer un lapsus linguae, rascarse o tener flatulencias; puede, accidentalmente, chocar con el cuerpo de otro participante [...] Puede tartamudear, olvidar su parte, aparecer nervioso, culpable o afectado: puede tener inapropiadas explosiones de risa, ira u otras reacciones que momentáneamente lo incapacitan como interactuante. (1997, p. 63)

De tal forma, para Goffman las expresiones corporales contribuyen al proceso de significación en la interacción social. A modo de ilustración: existe una diferencia en la significación de una frase al enunciarla con el semblante serio que al decir lo mismo con risa; así como tiene distintas implicancias para la interacción que ría una sola persona en una interacción grupal a que lo hagan varias a la vez.

Por su parte, Boltanski ha puesto atención al rol del cuerpo en distintos periodos de su carrera. En un primer momento (Boltanski, 1971), destaca el uso social que le cabe al cuerpo, más allá de las cuestiones de necesidad y funcionalidad de este, en tanto permite expresar simbólicamente. Más adelante (Boltanski, 2011; Boltanski \& Thévenot, 1999), en relación a sus desarrollos sobre la crítica, muestra cómo la posesión de un cuerpo, necesariamente situado en el espacio y tiempo, está vinculado con la construcción de un punto de vista particular. En tal sentido, el cuerpo y sus expresiones son significantes -es decir, generan significado-, así como la corporalidad contribuye a constituir una posición desde la que se interpreta el mundo al derivar necesariamente en un punto de vista.

En el campo de los estudios aplicados sobre el cuerpo, destacan las líneas de investigación que buscan analizar componentes particulares de la comunicación no verbal relativos al cuerpo (Antes, 1996; Birdwhistell, 1970; Harrigan \& Rosenthal, 2008; Poyatos, 2002). En particular, se han concentrado en el estudio de la kinésica y la mirada9 . Estos son componentes de la comunicación no verbal que, junto al significado y entonación de los enunciados, determinan lo que se comunica. Por lo tanto, la expresión de juicios críticos no sólo considera frases con un sentido literal, sino también un contexto expresivo compuesto

\footnotetext{
${ }^{9}$ Siguiendo la conceptualización de Harrigan (2008), la kinésica refiere a las acciones y posiciones del cuerpo, la cabeza y los miembros. La mirada, por su parte, involucra los movimientos y la dirección de los ojos en la interacción visual.
} 
por los movimientos y posiciones del cuerpo, así como la mirada. Un juicio crítico no es sólo la enunciación de una frase verbal, sino que también comprende la corporalidad que acompaña ese acto de enunciar, donde destaca el movimiento de la cabeza y los miembros, junto a la mirada.

Aunque las expresiones corporales tienen significados asociados, estos no pueden atribuirse convencional y sistemáticamente a un único significado literal; al menos no al nivel en que se hace con las expresiones verbales. En otras palabras, no se cuenta con un diccionario de movimientos y expresiones no verbales. Esto se debe a que la relación entre los códigos verbales y no verbales no es directa. No es posible establecer una conexión exacta entre unos y otros, como si mover un brazo pueda tener un significado igual de definido que el de una palabra. Aquello, sin embargo, no imposibilita determinar el significado de este tipo de expresiones: se trata más bien de definir su significado atendiendo a su realización y contexto.

Por lo general, los individuos se encuentran constantemente interpretando las señales corporales. Dentro del contexto en que se enuncia un discurso verbal cobran significado los movimientos del cuerpo, la cabeza, así como las miradas. Sin embargo, no siempre los actores que interpretan estas señales están completamente atentos:

A menos que estemos muy distraídos, es probable que estemos continuamente monitoreando y procesando las señales que emanan de las personas a nuestro alrededor, pero incluso cuando estamos distraídos o no prestando atención conscientemente, las señales en la periferia de nuestra atención son usualmente procesadas de forma inconsciente. (Hall, Bernieri, \& Carney, 2008, p. 238 traducción propia).

En términos operacionales, Harrigan (2008) destaca una serie de aspectos relevantes a tener en cuenta a la hora de estudiar la kinésica y la mirada: 1) Todavía existe una baja estandarización en la forma de codificar el movimiento del cuerpo; 2) Las dos partes del cuerpo que acaparan la mayoría del movimiento son la cabeza y las manos; 3) Los movimientos co-ocurren, por ejemplo, sonreír y asentir o apuntar con la mano y mover la cabeza para terminar el turno de habla; 4) Existen convenciones sociales que orientan nuestros comportamientos según reglas aprendidas culturalmente que indican cuándo es apropiado expresar una emoción y a quién se le pueden presentar estas. 
Sobre el último punto, Goffman (1966) desarrolló profusas observaciones sobre el comportamiento no verbal aceptado en distintos encuentros sociales públicos y privados tales como reuniones de trabajo, ceremonias y áreas de espera. Se trata de problematizar, por ejemplo, cómo lo que aparece como una posición neutra y poco significativa de los cuerpos en áreas de espera de un aeropuerto, donde nadie sostiene la mirada por mucho tiempo sobre el resto, es una forma de aparecer poco amenazante ante el resto, resguardando así el orden y tranquilidad del conjunto de individuos.

\subsection{Marcos de referencia de la crítica}

El contexto general donde se despliega la crítica, lo que en Chile se ha tendido a denominar como un neoliberalismo maduro o avanzado - una de las formas actuales del capitalismocon un régimen democrático de partidos fuertes (Garretón, 2003), marca su trasfondo estructural. Sin embargo, los marcos de referencia de la crítica social no provienen exclusivamente de lo que predomina en la realidad. La existencia de la reflexividad posibilita otros marcos de referencia, aparte del que se encuentra más asociado con el contexto, en tanto pueden imaginarse y desarrollarse otras realidades posibles. Para especificar los marcos de referencia de la crítica, recurrimos a los dos principales identificados por Dubet (2013): la igualdad de posiciones y la igualdad de oportunidades. Además, agregamos un tercero que ha sido destacado en la investigación empírica reciente en Chile: la igualdad de trato (Araujo, 2016; Mac-Clure \& Barozet, 2016). Este último, además, se relaciona con los hallazgos sobre justicia procedimental, según la que para las evaluaciones de justicia no solo son relevantes los resultados, sino también los procedimientos con que se obtienen los últimos (Thibaut \& Walker, 1975; Tyler \& Blader, 2003).

La igualdad de posiciones agrupa principios de justicia relativos a las desigualdades producidas por la estructura social. En la tradición sociológica existen innumerables ejemplos del tipo de desigualdades sociales que se producen ya sea por clase, género, raza, etnia, nacionalidad, nivel educacional, entre varios otros. Las críticas que denuncian este tipo de desigualdades suponen que es precisamente la desigual posición en el espacio social la que origina la injusticia. Desde los principios de la igualdad de posiciones, los diferenciales de recursos, estatus o reconocimiento dan lugar a situaciones injustas que privilegian a aquellos en posiciones aventajadas, por el solo hecho de estar en tal posición -y no, por ejemplo, por 
ser un legítimo merecedor de ese lugar o las recompensas asociadas-. Desde este marco se critica la asociación de recompensas desiguales a posiciones distintas en la estructura social. Un argumento central a este marco es de carácter colectivista, según el que lo social es producido por todos, asumiendo que el trabajo conjunto es necesario, por lo que no es viable una sociedad sin las posiciones desaventajadas. Ahora bien, cabe resaltar que no todas las desigualdades producidas por las posiciones sociales son consideradas injustas.

El marco de igualdad de oportunidades reúne principios de justicia que abordan el problema lo (in)justo de las desigualdades sociales desde otra perspectiva. En este caso, las desigualdades sociales se legitiman en la medida que responden a una carrera o competencia donde hubo condiciones igualitarias para participar. Si todos comienzan con las mismas oportunidades, los resultados de la competencia son justos ya que responden al esfuerzo de cada participante. El nivel de desigualdad de los resultados, entonces, es un reflejo de los méritos realizados. Por lo mismo, la principal imagen que posee este marco de referencia de la crítica corresponde a la meritocracia. Lo injusto, según este marco, es el desbalance de las oportunidades y el cooptar la posibilidad de desarrollo a quienes quieren tomar parte en la competencia.

El tercer marco de referencia corresponde a la igualdad de trato, donde se alojan principios de justicia enfocados en el proceso de interacción social. Desde este marco, no obstante existan desigualdades de posiciones y de oportunidades, lo que importa es que se respete de manera igualitaria a todos en el trato cotidiano. Lo que ocurre en las interacciones cotidianas se considera como una cuestión de relevancia para evaluar lo justo de una situación o hecho, por lo que desde este marco se enfatiza el rol de los procesos antes que el de los resultados. Por tanto, una crítica común desde este marco se refiere al maltrato recibido en distintos contextos sociales y entre individuos de posiciones equivalentes o desiguales.

Como puede apreciarse de la descripción de estos tres marcos, no se trata de formas excluyentes para evaluar lo que es justo en la sociedad. Estos marcos pueden coexistir tanto a nivel colectivo como individual, incluso con cierto nivel de contradicción en cada nivel. No se trata de marcos racionalizados y explícitos que se utilizan de manera impecable e indefectible al juzgar, sino de matrices que sintetizan las tres principales áreas de principios de justicia del contexto analizado. 
En suma, el estudio de la crítica social debe considerar tanto factores agenciales, como estructurales y culturales para dar cuenta de esta de manera integral. Las propuestas teóricas sobre la crítica permiten posicionar la pregunta por la misma como un mecanismo generativo tanto de cambios como de continuidades en la realidad social. La generación de estos se enmarca en tres marcos de referencia que sintetizan los principios de los juicios críticos, así como permiten evaluar en qué sentido se denuncia la realidad. 


\section{Marco metodológico}

Con el fin de satisfacer los objetivos planteados se propone una estrategia metodológica que permita observar los juicios críticos en contextos de interacción. El presente acápite describe el material analizado, la estrategia metodológica utilizada para la investigación, así como la unidad de análisis y de observación consideradas. Finalmente, se presentan los participantes de los grupos estudiados.

\subsection{Material de análisis}

El material analizado corresponde al producido en el proyecto Fondecyt 1130276 "Justicia social y tolerancia a la desigualdad: análisis subjetivo de la diferenciación social en un régimen neoliberal maduro" a cargo de Emmanuelle Barozet. En este proyecto se desarrolló una adaptación del juego de clasificaciones diseñado por Boltanski y Thévenot (1983) en la década de 1980. Se trata de un dispositivo, similar en su organización a un grupo focal, donde grupos de personas interactúan a partir de las instrucciones de un juego con naipes que representan individuos de la sociedad. El contexto lúdico conlleva una interacción más similar a la cotidianeidad que otras técnicas grupales comúnmente utilizadas, como el grupo focal o el grupo de discusión. Por lo mismo, el orden de interacción que tiene lugar es adecuado para observar aspectos relativos a normas y preferencias sociales, ya que los participantes interactúan menos atentos al rol del moderador con los eventuales sesgos hacia la deseabilidad social que esto puede conllevar.

Como se ha destacado, el estudio de la crítica social y de los juicios críticos debe considerar la dimensión pragmática en que se realizan. El uso de este juego propicia una situación donde tal dimensión puede ser observada en grupos que fueron organizados según la pertenencia a distintas clases sociales de los participantes. La definición conceptual y operacional de clases sociales se hizo siguiendo el esquema de Erikson, Goldthorpe y Portocarrero (Erikson \& Goldthorpe, 1993), adaptado para Chile. En cada grupo se resguardó la participación de hombres y mujeres de distintas edades. Una descripción pormenorizada del diseño de los juegos se encuentra en el documento de trabajo del Proyecto Desigualdades (2013).

Los juegos de clasificaciones analizados aquí tuvieron lugar durante el año 2012; consistían en exponer a grupos de seis jugadores de la misma clase social un set de 62 naipes, donde cada naipe representaba a una persona de Chile, de la que se presentaba una fotografía, su 
ocupación, religión, edad, comuna de residencia, rango de ingresos y nivel educacional. Los perfiles de las personas fueron construidos con datos de las personas reales en la muestra de la Encuesta Nacional de Estratificación Social realizada el 2009 en el marco del Proyecto Desigualdades. El juego consistía en que los jugadores tenían que clasificar estos naipes según grupos que consideraran representativos de la sociedad, darle un nombre a cada grupo y exponer los criterios para la construcción de los mismos entre los mismos jugadores. De tal manera, los jugadores se veían enfrentados a tener que contrastar sus formas de clasificación de las personas en el espacio social con las de sus pares. Durante la interacción surgían juicios críticos, ya sea a partir de los personajes representados en los naipes, los grupos conformados por los mismos jugadores, o bien la forma en que se establecieron agrupaciones.

En particular, el material que se analiza corresponde a la discusión que ocurría en la última parte de la interacción donde, después de haberse separado en dos tríos para consensuar una clasificación en cada uno, entre los seis jugadores se explicaban qué clasificación habían hecho, cómo habían llegado a esta y conversaban sobre los criterios utilizados. Los juegos fueron grabados con video y audio para luego ser transcritos. En las interacciones era común que surgieran juicios críticos - como se verá en el siguiente capítulo-, que eran eventualmente apoyados, rechazados o ignorados por los otros jugadores. Por lo mismo, se trata de un material rico en juicios críticos enunciados en un contexto de interacción grupal.

\section{$\underline{5.2 \text { Estrategia metodológica }}$}

Se utiliza una estrategia cualitativa de análisis, en el marco de un estudio de carácter descriptivo, para dar cuenta del objetivo propuesto a partir del material producido en los juegos de clasificaciones.

Para realizar un análisis de las interacciones en los grupos se consideraron los factores discursivos presentes en estas, donde se considera tanto lo enunciado, como las formas de realizarlo y lo implícito en esto. La primera parte del análisis consistió en producir una codificación de las interacciones en los seis grupos, terminando con un inventario completo de todos los juicios críticos enunciados en cada grupo. De esta manera, el foco del análisis se encuentra en estos juicios críticos y su contexto de enunciación en la interacción grupal. 
Respecto al análisis, se utilizó el método de análisis estructural del discurso (Martinic, 2006). Este método consiste en organizar los juicios críticos y codificarlos a partir de las distinciones señaladas anteriormente para definir la relación entre los marcos de referencia de los juicios críticos y el nivel de reflexividad en que operan. También se atendió a la forma de los juicios críticos, considerando la forma en que son enunciados, y el objeto de los mismos, es decir, hacia qué se dirige la crítica. Desde la caracterización pormenorizada de los juicios críticos se extrajeron las implicancias de estos en su contexto de realización, vale decir, considerando especialmente cómo fueron recibidos por los otros jugadores. Este método fue pertinente dado que "desde el punto de vista del análisis estructural la circunstancia del discurso, cualquiera que ella sea, es una ocasión de la puesta en práctica de una estructura implícita que trasciende a la propia enunciación" (Martinic, 2006, p. 302), lo que permite relevar un contexto de realización donde coexisten distintos principios de justicia, a modo de marcos de referencia. En la misma línea, Martinic agrega que:

El análisis estructural no se dirige a comprender los efectos del discurso sobre el sujeto en particular sino que sobre la estructura simbólica de la cual participa. En efecto, para este enfoque, se trata de estudiar cómo el sujeto que habla es, a la vez, hablado por principios simbólicos que organizan su enunciación. (2006, pp. 302-303)

En este caso, se trata de principios de justicia que eran interesantes precisamente por el efecto supraindividual en que operan. A través de los marcos de referencia de la crítica, se pueden establecer relaciones que pasan a ser códigos, que se ponen en relación en el análisis, ya sea en una relación de conjunción, donde se refuerzan, o de disyunción, caso en que operan por oposición.

\subsection{Unidad de análisis}

La unidad básica analizada corresponde a los juicios críticos emitidos en el contexto de los juegos de clasificaciones. Por lo tanto, se trata de enunciados lingüísticos que tienen lugar en un grupo de seis personas más una moderadora, considerando componentes no verbales en su comunicación. El análisis presentado a continuación se basa, entonces, en la identificación, codificación y relación entre el conjunto de los juicios críticos enunciados en los seis juegos de clasificaciones. 


\subsection{Unidad de observación}

La unidad de observación corresponde a las interacciones en los juegos de clasificaciones que se configuran como un marco lúdico, a partir de la guía de una moderadora que proveía las instrucciones del juego y orientaba durante el proceso.

\section{$\underline{5.5 \text { Participantes }}$}

Con el fin de facilitar la lectura del siguiente capítulo de análisis, en la tabla 5.1 se detallan los seis grupos según clase social de la escala EGP y las características de los participantes asociados a su pseudónimo. Las abreviaciones de los identificadores de las clases sociales (I, II, IIIa, IIIb, IVb, VI y IX) provienen de la escala original de los autores (Erikson \& Goldthorpe, 1993), sin embargo en el análisis se mencionan con sus nombres por razones de inteligibilidad. 
Tabla 5.1 Participantes de cada grupo según clases sociales

\begin{tabular}{|c|c|c|}
\hline Clase social & Pseudónimo & Características \\
\hline \multirow{6}{*}{$\begin{array}{c}\text { EGP I: } \\
\text { Servicios Alta }\end{array}$} & Carolina & 32 años, ingeniera, casada, un hijo, dueña de casa, Ñuñoa \\
\hline & Ana & 51 años, terapeuta, casada, tres hijos, Las Condes \\
\hline & Gervasio & 30 años, ingeniero comercial, soltero, sin hijos, Providencia \\
\hline & Mónica & Abogada y corredora de propiedades, 3 hijos \\
\hline & Vicente & Abogado, casado, un hijo \\
\hline & Galo & 32 años, médico veterinario, una hija \\
\hline \multirow{6}{*}{$\begin{array}{c}\text { EGP II: } \\
\text { Servicios Baja }\end{array}$} & Andrea & 46 años, relacionadora comercial, separada, 2 hijas, La Florida \\
\hline & Máximo & 52 años contador auditor, casado, dos hijos \\
\hline & Nadia & 42 años, contadora, separada, dos hijos \\
\hline & Luciano & 40 años, analista y contador auditor, 2 hijos \\
\hline & Marcelo & 42 años, contador auditor, administrativo Isapre. $\$ 700.000$ \\
\hline & Silvana & 43 años, administrativa Parque Canaan, 3 hijos \\
\hline \multirow{6}{*}{$\begin{array}{c}\text { EGP IIIa: } \\
\text { Rutinas No } \\
\text { Manuales Alta }\end{array}$} & Celia & Secretaria ejecutiva, separada, dos hijos \\
\hline & Martín & Contador en gran empresa, casado, tres hijos \\
\hline & Demeterio & $\begin{array}{l}55 \text { años, técnico en armado de computadores, casado, tres hijos, San } \\
\text { Ramón }\end{array}$ \\
\hline & Catalina & 40 años, trabaja en municipalidad Peñalolén, casada dos hijos, Peñalolén \\
\hline & Clara & 39 años, dueña de casa, casada, sin hijos, Santiago \\
\hline & Lautaro & 51 años, técnico jurídico, viudo \\
\hline \multirow{6}{*}{$\begin{array}{c}\text { EGP IIIb: } \\
\text { Rutina No } \\
\text { Manuales Baja }\end{array}$} & Álvaro & 40 años, asesor de salud en Isapre, casado, 2 hijas \\
\hline & Fernando & 48 años, técnico en instalaciones sanitarias y junior, casado, 2 hijos \\
\hline & Mara & 48 años, camarera, 2 hijos \\
\hline & Bernardo & 31 años, técnico electromecánico, casado \\
\hline & Rita & 3 hijos, recepcionista, La Florida \\
\hline & Yessenia & 46 años, dueña de un almacén de barrio, casada, 3 hijos, La Pintana \\
\hline \multirow{6}{*}{$\begin{array}{c}\text { EGP IVb: } \\
\text { Trabajadores } \\
\text { Independientes }\end{array}$} & Isabel & $\begin{array}{l}64 \text { años, dueña de casa y vendedora de productos por catálogo, casada, } 2 \\
\text { hijas, La Florida }\end{array}$ \\
\hline & José & 57 años, comerciante de longanizas. $\$ 250.000$ \\
\hline & Raúl & 54 años, trabajador independiente, casado, 3 hijas, La Florida. $\$ 280.000$ \\
\hline & Inés & 37 años, dueña de casa, modista, casada, 3 hijos, Ñuñoa \\
\hline & Loreto & 40 años, contadora independiente y profesora de clases de baile, una hija \\
\hline & Leopoldo & 42 años, comerciante. $\$ 250.000$ \\
\hline \multirow{6}{*}{$\begin{array}{c}\text { EGP VI y IX: } \\
\text { Baja Integrada } \\
\text { (Manuales } \\
\text { Calificados y } \\
\text { No } \\
\text { Calificados) }\end{array}$} & Anita & 38 años, 2do medio, dueña de casa, dos hijos \\
\hline & Pamela & 41 años, 8vo básico, asesora del hogar, casada, tres hijos. $\$ 250.000$ \\
\hline & Pedro & 38 años, 1ero medio, maestro pintor, $\$ 270.000$ \\
\hline & Hernando & 75 años, 8vo básico, gásfiter, separado, 3 hijos. $\$ 260.000$ \\
\hline & Nadia & 43 años, auxiliar de aseo, casada, dos hijos, \$250.000, Peñalolén \\
\hline & Juan & 65 años, 8vo básico, carpintero mueblista, casados, dos hijas. $\$ 260.000$ \\
\hline
\end{tabular}

Fuente: Elaboración propia a partir de registros de campo del proyecto Fondecyt 1130276 


\section{La crítica ordinaria frente al espacio social}

Al participar en el juego de clasificaciones, los grupos de jugadores enfrentan una situación anómala en apariencia, pero una lógica cotidiana en el fondo. Si bien una persona común rara vez se sienta a ordenar las personas en el espacio social, a modo de un ejercicio taxonómico deliberado, día a día se van construyendo tipologías más o menos explícitas. La realidad social así lo exige, pues se hace necesario diferenciar a los sujetos en colectividades para lograr un desenvolvimiento individual menos complejo. El trabajador que interactúa con su jefe, en distintos empleos y períodos de su vida, sabe que existen ciertas características dispuestas en esta posición, independiente de la persona particular que la encarne. Cada vez que se enfrenta a un nuevo jefe, aplica sobre esta figura un esquema de expectativas y percepciones que ha adquirido a lo largo de su experiencia vital. Aunque distinga entre buenos y malos jefes, mantendrá una serie de expectativas, comportamientos y valoraciones hacia quien ocupe ese lugar. Algo similar ocurre con muchas otras posiciones y características de agrupaciones sociales. Se pueden asociar rasgos generales a quienes residen en un barrio, ejercen cierta profesión o poseen determinada nacionalidad; estas relaciones son producto de un trabajo de clasificación ejercido por los individuos, que está siempre sujeto a transformaciones.

En el presente capítulo abordaremos algunas interrogantes sobre la crítica ordinaria producida por los jugadores. En este caso, al haber organizado el juego de clasificaciones en sesiones donde participaron grupos homogéneos según clases sociales, cada una permite evidenciar los juicios críticos acerca de los diversos grupos sociales construidos por los participantes con los naipes. ¿Qué tan distintos son estos juicios? ¿En qué se diferencian? ¿Cuáles son sus regularidades? ¿Cuáles son los principios normativos que subyacen a estos juicios? Estas son las preguntas que guían esta indagación. Un aspecto relevante a considerar es la relación entre los juicios críticos y los procesos de reflexividad durante las interacciones. Ciertamente, como veremos, no es fácil identificar un proceso reflexivo de manera directa. Al caracterizarse como una conversación interna de un sujeto consigo mismo (Archer, 2010), se debe observar evidencia indirecta para analizar tales procesos. Por esto, utilizamos las evidencias manifiestas de los individuos en el contexto del juego: juicios críticos con sus expresiones verbales y no verbales, es decir, las formas de enunciación tales como las 
referidas al uso del cuerpo en la comunicación. A través de estos observables la crítica social enunciada da luces sobre su formación y los procesos que le subyacen.

Los siguientes apartados, entonces, analizan cómo se critica, específicamente en términos pragmáticos (6.1) y sistematizando los principios de justicia que subyacen a la crítica bajo la forma de marcos de referencia (6.2). Luego, se examina qué es lo criticado (6.3) para finalmente hacer una evaluación general del carácter de la crítica en los seis grupos focales, a la luz de los procesos de reflexividad y los tipos de juicios críticos que se distinguieron desde Boltanski (6.4).

\subsection{Las formas de la crítica}

Los juicios críticos emitidos durante el juego de clasificaciones son producto del intercambio comunicativo entre los jugadores y, por lo mismo, aparecen mayormente en sus diálogos, como resultado de la interacción más que como producciones individuales. Tanto es así, que una forma muy frecuente de los juicios críticos observados consiste en contra-juicios críticos, donde una persona pone en cuestión el estándar evaluativo de quien había emitido una crítica, generando un nuevo juicio crítico a su vez. El intercambio que produce los juicios críticos, entonces, puede ser positivo o negativo, pero siempre productivo en términos del desarrollo de los mismos, pues los juicios críticos tienden más bien a ser aceptados o rechazados, antes que ignorados. Así, estos juicios realizados se refuerzan o cuestionan durante la interacción, muchas veces a través de una nueva crítica.

Los elementos que destacan en la realización de los juicios críticos se encuentran en su contenido en términos verbales, por una parte, y en los factores contextuales que los acompañan, relativos a la comunicación no verbal, por otra. Lo referente al contenido verbal lo analizaremos en los apartados siguientes, sistematizándolo como los marcos de referencia (6.2) y los objetos de la crítica (6.3). En el presente apartado nos concentramos en los elementos formales y de contexto con el objetivo de dar una caracterización integral a la crítica social en su contexto pragmático. La primera tarea es, entonces, evaluar si el cómo se realizan los juicios críticos -en términos de la comunicación no verbal- exhibe efectos sobre las formas de reflexividad de los participantes.

El cuerpo tiene un lugar importante en el contexto: la voz, la mirada y los gestos son parte de los juicios críticos y evidencian regularidades significativas. Ya sea bajo una perspectiva 
según la que se incorporan estructuras sociales que se expresan en habitus (Bourdieu, 2007), o bien entendiendo el cuerpo como una parte significativa de lo que comunica en las interacciones sociales (Goffman, 1997), los usos del cuerpo permiten comprender aspectos relevantes de los juicios críticos. El caso de Bernardo, el jugador del grupo de rutinas no manuales alta sentado al fondo con una polera negra en la figura 6.1, permite ilustrar la disposición del cuerpo durante la crítica. La mayor parte del juego estuvo de brazos cruzados y muchos de sus comentarios los hizo en la misma posición. Incluso cuando lo interpelan directamente al mostrarle un naipe, como se puede ver en la figura 6.1, permanece tranquilo en una postura similar.

Figura 6.1 Fotogramas de distintos minutos durante el juego de Rutinas no manuales baja
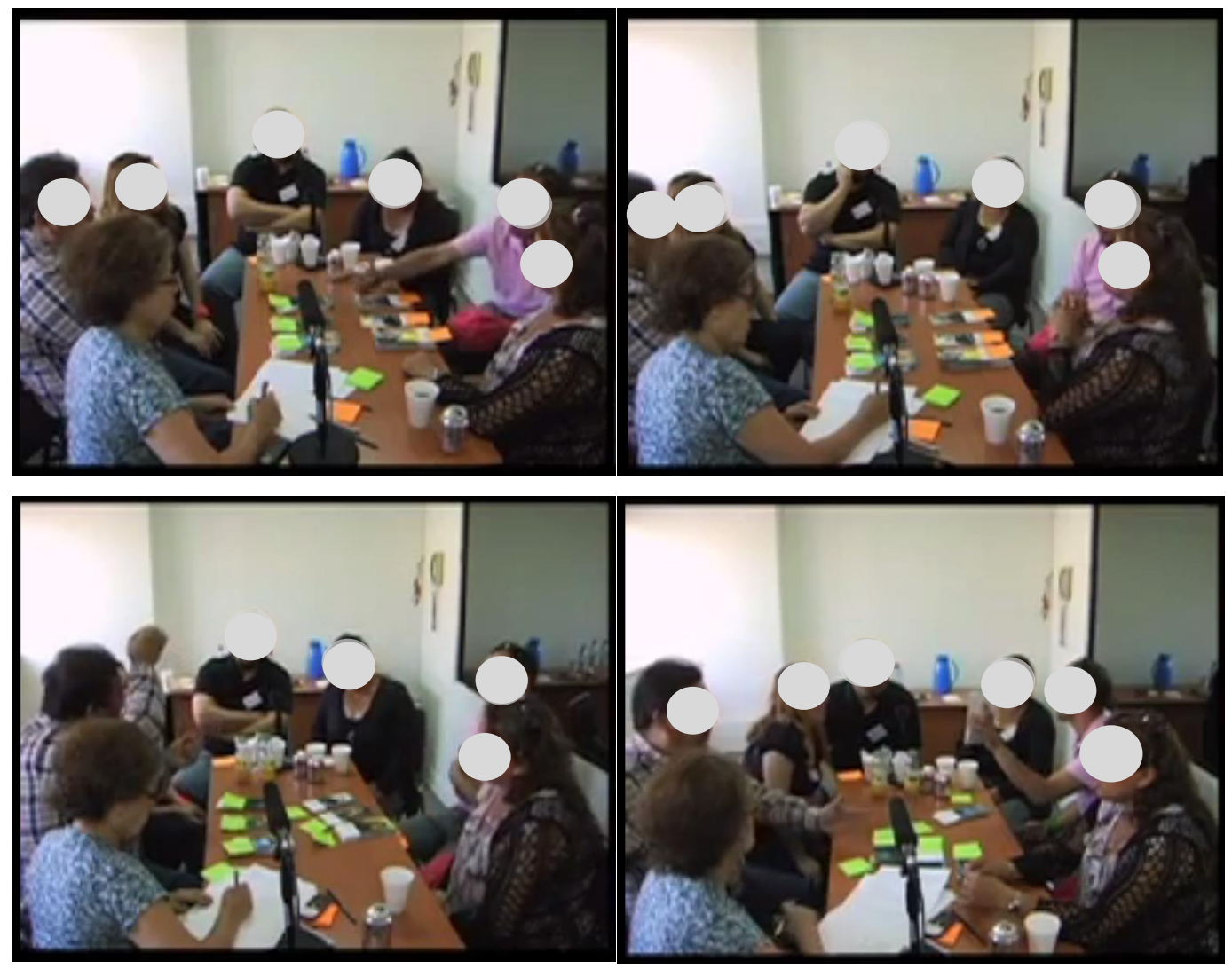

Las excepciones a esta posición se pueden ver en la serie de fotogramas de la figura 6.2, donde Bernardo mueve sus brazos mientras hace distintos juicios críticos. En esta ocasión, habla de cómo existen empleadores que prefieren contratar trabajadores peruanos porque saben que les pueden pagar menos, así como en algunas ocasiones son los técnicos los que 
realmente sacan adelante los trabajos en una fábrica, en comparación con los ingenieros que se llevan el crédito. De hecho, él trabaja como técnico electromecánico y aclara que está hablando desde su experiencia. En la línea de los tipos de juicios categorizados por Boltanski, se trataría más bien de un juicio existencial en este caso, al estar fundamentado en la vivencia subjetiva.

Asimismo, en el grupo de los trabajadores de la clase de servicios baja también se evidencia un movimiento más intenso de los brazos cuando se emiten juicios críticos. Por ejemplo, Andrea, una relacionadora comercial, toma y ondea la carta representando una mujer mapuche con los ingresos más bajos de la baraja mientras habla de cómo en la empresa donde trabaja las empleadas del aseo son explotadas dado su bajo sueldo y su fuerte carga de trabajo. A la vez que dice "a esta gente la explotan", le da varios golpes con la punta de su dedo al mismo naipe. Apenas Andrea termina de hacer su juicio crítico, Sandra lo enfatiza y generaliza diciendo "Exactamente, a la gente la explotan" mientras asiente dos veces con la cabeza.

Ocurre lo mismo en todo el resto de los juegos, es decir, en los de las clases sociales de servicios alta, rutinas no manuales alta, independientes y pequeños empresarios, así como de trabajadores manuales. Los momentos de mayor intensidad kinésica, individual y colectiva, corresponden a intercambios comunicativos donde se emiten juicios críticos. Además, es transversal el que las miradas se concentren en quien hace un juicio crítico, prestándole mayor atención. Aunque esto también ocurre así en varias otras situaciones, además de en la realización de juicios críticos, son estos últimos los que suscitan una atención particular a lo largo de la interacción grupal. La dirección de la mirada puede variar durante las interacciones y, en ese sentido, esta atención particular constituye un hallazgo. Si bien, en general las miradas se concentran sobre quienes hablan, esto no necesariamente es así según se observa ocurre en muchas otras interacciones durante los juegos. Quien elabora juicios críticos generalmente pasa a ser un foco de atención, a diferencia de otros comentarios que tienden más a ser interrumpidos o desestimados en el flujo de la conversación. Esto constituye un primer indicio sobre la presencia de un mayor nivel promedio de reflexividad en el intercambio de juicios críticos, en tanto los participantes se ven inmersos con mayor atención en los momentos asociadas a la crítica social. 
Las interrupciones a quien hace un juicio crítico son principalmente aquellas que apuntan a apoyarlo o contradecirlo con otro juicio crítico. Este último caso es el de lo que denominamos contra-juicio crítico, correspondiente a los juicios críticos que cuestionan o rechazan otro recientemente emitido. Si bien su diferenciación es principalmente de contenido, son tan comunes que permiten distinguir una forma de los juicios críticos en la interacción. Durante el subsecuente análisis se darán una serie de ilustraciones de este patrón.

En uno de los fotogramas de la figura 6.2 aparece Bernardo en una posición más bien quieta. Esta es la disposición de su cuerpo frente a un matiz que hace Rita, la primera mujer a la derecha que está moviendo sus manos. Esta acotación fue provocada por el juicio crítico de Bernardo sobre los técnicos y los ingenieros, haciendo que en el cuerpo de Rita converjan un movimiento de manos y el cuestionamiento de lo que percibe como una generalización indebida de su interlocutor. A modo de contra-juicio crítico, Rita señala "yo creo que están los dos extremos", refiriéndose a que hay tanto ingenieros que no son un aporte al proceso de producción, así como otros que sí aportan.

Figura 6.2 Fotogramas de distintos minutos durante el juego de Rutinas no manuales baja
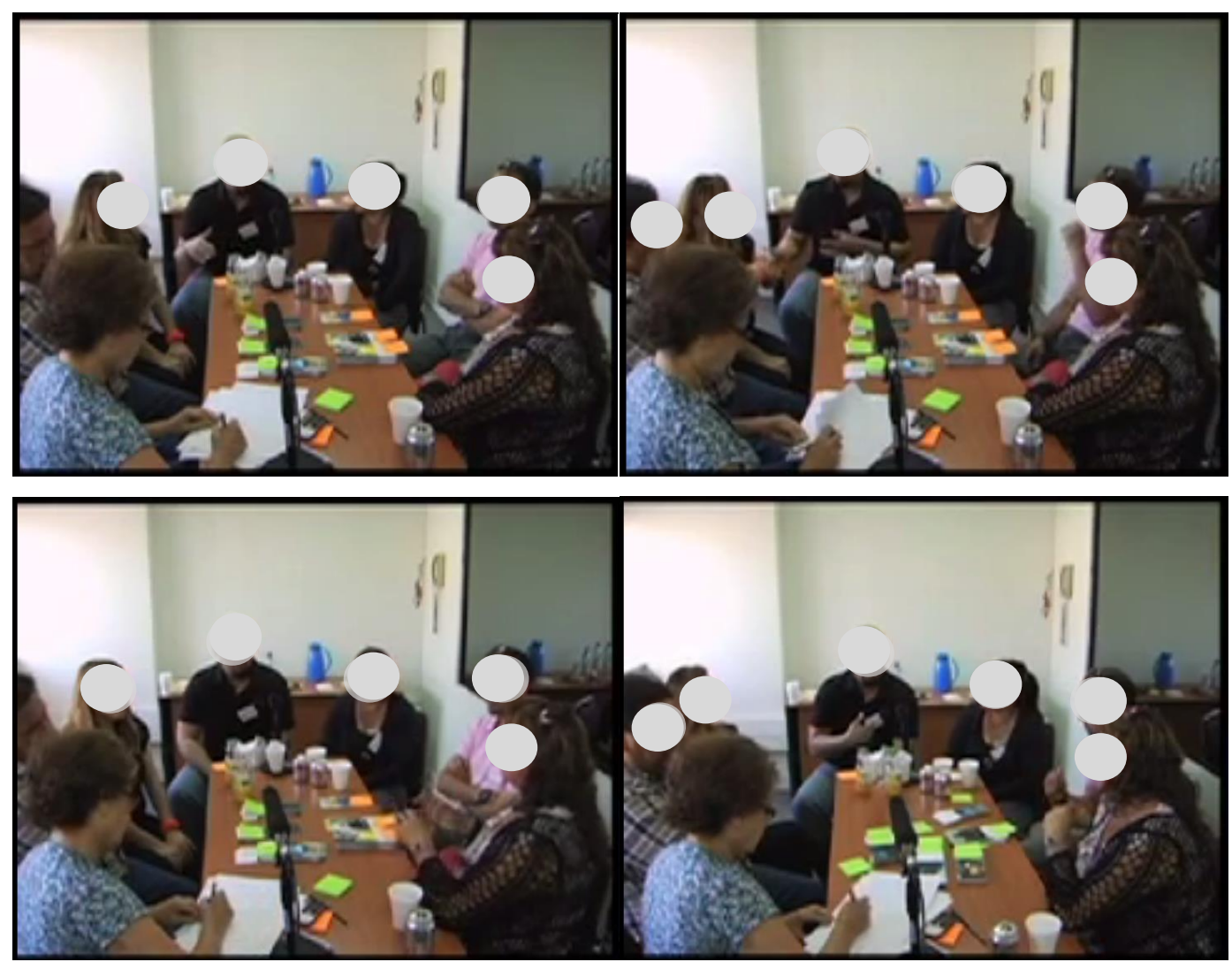
La forma de contra-juicios críticos se observa en los juegos de todas las clases sociales. En el grupo de trabajadores independientes, un comerciante habla de la existencia de ciertas "barreras de entrada" entre los grupos de naipes que han construido. Dentro de estas barreras menciona la diferencia que, desde su punto de vista, se produce por haber estudiado en universidades con distintos grados de prestigio, incluso entre las privadas no tradicionales. Raúl, un trabajador independiente que reside en La Florida, replica: "En eso estás equivocado tú. ¿Sabes por qué te digo que estás equivocado? Porque mucha gente, profesores de universidades tradicionales, hoy día están trabajando por más plata en las universidades privadas". Y añade: "Así que yo te digo, que pueden salir profesionales de universidades privadas tan buenos o mejores como de las universidades estatales". Si bien en la respuesta de Raúl hay una desviación del sentido del juicio crítico inicial, su ánimo de contravenir los criterios del juicio emitido es ilustrativo de la forma en que operan los contra-juicios críticos.

El contraste entre los criterios - expresados en juicios críticos- para evaluar una misma situación puede observarse en otra interacción del mismo grupo. La evaluación de la posición en el espacio social de las mujeres que son dueñas de casa difiere sustantivamente entre los jugadores de la clase de trabajadores independientes. Una jugadora refiriéndose a las dueñas de casa señala: "Nosotros le pusimos las dependientes, porque ellas dependen, porque ellas se esfuerzan lo mínimo", lo que es inmediatamente reforzado por Raúl: "Mírenle la carita, porque todo en la vida se lo dan, no se esfuerza nada". Frente a lo dicho, otro participante menciona: "Trabajan día y noche, problemas, tienen que asumir la administración del hogar, entonces son la reina", destacando la idea de que, en tanto reinas, toman la trabajosa tarea de gobernar el hogar. A modo de síntesis del contraste en la evaluación de las dueñas de casa, coinciden en clasificarlas como un grupo aparte, bautizándolo como "reinas dependientes".

Los jugadores de la clase social servicios alta dan cuenta de una dinámica presente en el intercambio de juicios y contra-juicios críticos. Como este intercambio supone una diferencia en los criterios evaluativos -en términos de los marcos de referencia de la crítica, como veremos más adelante -, puede llevar, en primer lugar, al reconocimiento explícito de tal diferencia y, luego, a la consecución de una conciliación o al establecimiento de una brecha insalvable. 
En el caso de la clase social de servicios alta, se mantiene una línea de discusión durante toda la interacción entre los seis jugadores donde unos respaldan una clasificación basada en lo cultural o educacional y otros defienden una fundada en criterios sociales más amplios. Gervasio, un ingeniero comercial joven, discute explícitamente con Galo, un médico veterinario, sobre qué tan relevante es la comuna de residencia para formar grupos sociales. Este último comenta: "Yo tengo un gran amigo y el weón vive en Recoleta, y si tú lo mirai es de Las Condes, hasta como habla, cachai. Y tiene full casa y todo", a lo que Germán increpa: “¿Pero tú me vai a decir que un arriendo en Vitacura es lo mismo que un arriendo en La Florida?”. Frente a la insistencia de Galo en que sería reduccionista pensar que las comunas realmente dividen a tipos de personas y la propuesta de otra jugadora en hacer sólo dos grupos, Gervasio responde:

Pero si tú me decí eso, yo te voy a decir tengo amigos en La Florida, tengo amigos en Las Condes, tengo amigos en Vitacura. Pero si tú me decí que vivir en Vitacura o en Las Condes es lo mismo que vivir en La Florida, no es lo mismo. Y las clases sociales sí tienen un peso grande en eso [...] Nosotros [él y dos otros participantes] estamos en un consenso al final de como más categorías. Pero si tú me decí clases sociales y como que me mezclai que las comunas son como vivir en cualquier comuna como que... a nosotros que nos costó llegar a un consenso y llegamos a un consenso viendo los perfiles analizando súper, $\mathrm{y}$ al final tuvimos discusiones y todo, llegamos a un consenso como muy claro como por comunas.

Finalmente, Galo reconoce que existen criterios distintos y, al parecer, no conciliables: "Es que lo que pasa, vuelvo a reiterar, nosotros nunca pescamos la clase social". De tal forma, en el intercambio de juicios y contra-juicios críticos Galo y Gervasio explicitaron los distintos criterios utilizados para conformar las agrupaciones de naipes y reconocieron que existe una diferencia en las implicancias de estos para clasificar a las personas en la sociedad.

La dinámica descrita de juicios y contra-juicios críticos exhibe un segundo indicio sobre la reflexividad asociada a los procesos de crítica social. El carácter generativo de la crítica, en este esquema de un juicio que provoca un contra-juicio, también da cuenta de cómo se activan procesos reflexivos en la interacción. Los cuestionamientos que se abren durante estas interacciones suponen niveles de elaboración y creatividad propios de un mayor nivel de 
reflexividad en relación al resto de la interacción. De manera que no sólo hay una mayor atención durante la enunciación de juicios críticos de parte del colectivo, sino que esa atención se traduce en elaboración y eventuales contra-juicios críticos por parte de otros participantes.

Aparte de las miradas, los gestos y las posturas corporales, cabe subrayar otro elemento de la comunicación no verbal asociado a los juicios críticos. La risa, siempre compartida por más de un participante, permite romper tensiones o disminuir la severidad de un juicio crítico. Siguiendo con la dinámica descrita del intercambio de juicios y contra-juicios críticos, se observa que la risa es una salida posible a los criterios irreconciliables. Por ejemplo, la interacción de los trabajadores independientes respecto a las "reinas dependientes", con juicios y contra-juicios críticos, está acompañada de constantes risas entre los participantes.

Catalina y Demeterio, jugadores del grupo de la clase social rutinas no manuales alta, contraponen sus juicios críticos frente al criterio que usó el último y otros dos participantes para agrupar ciertos naipes. Construyeron un grupo de técnicos y universitarios que, según ellos, ganaba una remuneración baja para su nivel de formación, bautizándolo como "conformistas". Demeterio agrega: "nosotros pensamos que se conformaban con eso", explicando el criterio con que clasificaron esos naipes y haciendo una crítica a quienes están representados en las cartas. Catalina ya había tenido una ligera risa al escuchar el nombre del grupo y cuando oye esto último lo repite con una risa evidente -"Se conformaban..."-, y luego agrega: "Es lo que pagan en este país". A esto Demeterio replica: "Pero un profesor no puede ganar tan poco, po", generando un nuevo contra-juicio crítico de Catalina: "No ha visto las marchas este caballero", aludiendo de esta forma a una experiencia personal y generando un juicio de carácter existencial. Al decir esto ríe fuerte, así como otros participantes también ríen o sonríen. Estas risas no corresponden a una falta de control de expresión (Goffman, 1997), sino a una forma significativa de complementar la comunicación verbal en la interacción grupal. Los participantes muestran su acuerdo sobre lo risible de la crítica de Demeterio. De esta forma, se evidencia cómo la risa acompaña ciertas expresiones críticas que, en este caso, implican un rechazo al juicio crítico original de Demeterio sobre la existencia de personas que se conforman con poco, mientras depende de su voluntad obtener más. 
El grupo de jugadores de la clase social de trabajadores manuales también muestra otra forma en que la crítica deviene risa. Pamela, una asesora del hogar, y Pedro, un maestro pintor, presentan perspectivas opuestas sobre las personas que tienen posiciones de mayores recursos monetarios y educacionales. Cuando la moderadora les pide a todos que escojan un nombre para el grupo de naipes que armaron con estos perfiles, Pedro propone denominarlos "triunfadores". Para Nadia, una auxiliar de aseo, se trata de personas que tienen una "mejor calidad de vida”. Al escuchar eso, Pedro dice “Triunfadores en su calidad de vida, ¿o no?”. Pamela rápidamente replica 'No po', porque ellos no están moviendo un dedo para tener lo que tienen po"”. Entonces Pedro argumenta: "Pero, ¿qué culpa tienen ellos po'?” y, sin que lo vea Pamela, le hace una mueca chistosa a Hernando, que está a su lado. De esta manera, articula una contra-crítica con su cuerpo, comunicando no verbalmente su desacuerdo. Al instante, Hernando dice "No tienen la culpa po", lo que refuerza Pedro repitiéndolo y luego preguntándole a Pamela "¿A ti no te gustaría ser así?”. Juan, un carpintero mueblista, interviene alargando la frase con una voz seria "Apitutados". Varios jugadores ríen, mientras Pamela responde con un largo "Sí, po".

Asimismo, un jugador de la clase social rutinas no manuales alta encuentra su juicio crítico aislado por la risa y el silencio. Se trata de Lautaro, un técnico jurídico de cincuenta años, quien intenta hacer ver a través de juicios de realidad que existen condicionantes estructurales que afectan la posición de algunos individuos de las cartas. En el caso de un naipe que representa a un temporero de Curacaví con ingresos por debajo del sueldo mínimo y que no terminó la educación básica, Lautaro señala: "hay montones de trabas que tiene en su... en su vida, que le han puesto objeción a eso, entonces...”. Frente a esto, Martín, un contador de una gran empresa, marca un claro contraste: "perdón, eso tú no lo sabes, porque yo conozco ene cantidad de gente que trabaja en un lado, otra semana en otro, porque no le gusta la pega, porque no le gusta trabajar...”. Lautaro insiste enfatizando que Curacaví es una zona rural. Martín, a su vez, mantiene su postura "pero si tú quieres, te superas y te vas para otro lado. Es, es personal". Catalina, funcionaria de una municipalidad, agrega con una intención chistosa: "Está a una hora de Santiago; trae dulces de Curacaví y los vende en Santiago", provocando la risa de algunos participantes. Lautaro dice "A mí todo lo que yo opino, pa' atrás" y deja que los intercambios sigan entre los otros participantes. Continúan los comentarios en la dirección de que es principalmente un factor individual el que está detrás 
de cómo le vaya a cada uno, con frases como la de Clara que dan cuenta de juicios de verdad donde se refuerza la idea de una realidad meritocrática - "Todo va en la superación de cada uno" - o la de Martín - "Es una cosa de superación [...] Hoy día uno gana lo que quiere ganar nomás" -. Al escuchar este último juicio crítico, Lautaro vuelve a intervenir: "Estudié algo para... pa' luchar contra el sistema”. Celia, a su lado derecho, da una sonada risa, mientras que Clara, al lado izquierdo de Lautaro, acompaña la risa sonriendo y levantando la cabeza. Martín expresa un juicio de realidad con un tono socarrón: "Pero el sistema es así”. El ritmo de la conversación se ralentiza y Lautaro, mientras los otros participantes están en silencio, enfatiza "Pero se puede luchar contra el sistema". Y haciendo un movimiento rápido con su cabeza, repite: "se puede luchar contra el sistema". Al terminar se producen unos segundos de silencio.

Como hemos visto, existen elementos importantes para la caracterización y debida comprensión del sentido de los juicios críticos en su contexto y aspectos formales. Cuestiones relativas a la comunicación no verbal, como los movimientos y la disposición del cuerpo, el uso de la risa, de los silencios y la atención de los participantes, juegan un rol significativo en la emisión de juicios críticos. También aparece una forma generalizada de respuesta a estos juicios, que hemos denominado contra juicios críticos, donde los primeros dan pie rápidamente a una oposición a sus criterios evaluativos a través de la emisión de una nueva crítica. Se observa que los juicios y contra juicios críticos constituyen una unidad durante la interacción que supone momentos de mayor reflexividad, considerando la atención de los participantes según cómo dirigen la mirada, así como una mayor elaboración de parte de estos en los cuestionamientos realizados. Antes que ser ignorados, los juicios críticos tienden a ser atendidos y procesados por los sujetos en la interacción. De tal forma, se evidencia que la crítica tiende a ser respaldada o cuestionada con una nueva crítica a su vez. Aquello se asocia con procesos más reflexivos que los observados en otros momentos de la interacción grupal.

\section{$\underline{6.2 \text { Los marcos de referencia de la crítica }}$}

La existencia de distintos criterios de evaluación en los juicios críticos es evidente hasta aquí. Ahora bien, es necesario revisar con mayor precisión el origen de esas diferencias para caracterizar la crítica social. Vale la pena estudiar los marcos de referencia de la crítica social 
pues, siguiendo a Coleman (1990), es necesario interrogarse por el surgimiento de las normas sociales sin tomarlas sólo como parte del contexto dado para un análisis que no solo asuma su existencia, sino que permita iluminar cómo emergen y operan.

Cabe recordar la diferencia entre un juicio crítico, como la práctica comunicativa que hemos visto, y una crítica social, que se distingue analíticamente como el sentido del juicio. Los criterios que sirven como base a la crítica social son, de hecho, normas sociales que los individuos internalizan y, en algunos casos, comparten. Tales normas, en términos generales, constituyen los criterios de justicia con que se evalúan fenómenos de la realidad social. Así, un marco de referencia es un conjunto de normas racionalmente coherentes que sirven de trasfondo a la crítica, como guías respecto a lo que se considera justo o injusto.

Otro aspecto relevante para analizar, aparte de las formas de constitución de los marcos de referencia que son fuentes de legitimidad, en términos de ideal, es cómo estos contrastan con las experiencias sociales (Araujo, 2015). Aquello supone que lo que es expresado, en términos de ideales o marcos de referencia, no tiene necesariamente un correlato con lo que se percibe en la praxis de la realidad social y, tampoco, con la acción misma de los individuos. En otras palabras, no porque se crea en ciertas reglas se actúa coherentemente con esa creencia; menos aún implica que la realidad en general opere bajo esas directrices en particular. Por lo tanto, los marcos de referencia constituyen una mirada o estándar evaluativo que sirve como herramienta de análisis de la realidad, pero que no se corresponde necesariamente con la acción. Por otra parte, existe una relación entre los marcos de referencia y las experiencias sociales, según los primeros afectan a las segundas y viceversa, en distintos grados. Como veremos, esta influencia mutua es ilustrada por la interacción en el juego de clasificaciones.

Los marcos de referencia de la crítica consideran criterios de distintos niveles de complejidad. Se puede tratar de criterios de evaluación simples: por ejemplo, un jugador del grupo de rutinas no manuales baja señala que las empresas constructoras, por ahorrarse la compra de zapatos de seguridad, le piden a sus empleados que lleven zapatos propios, economizando en un elemento que se considera importante para la seguridad de los empleados. Entonces, detrás de este juicio crítico se evidencia el criterio de justicia que evalúa binariamente si se resguardan las condiciones de trabajo o no. Igualmente, pueden 
entrar a operar criterios de evaluación más complejos, donde, por ejemplo, se considera un balance entre igualdad de oportunidades en el desarrollo de la vida y una justa atención a las desventajas sociales poseídas, como ser mujer, nacer en una familia pobre, entre otras. A modo de ilustración, Loreto, una contadora del grupo de trabajadores independientes, explica los criterios con que ordenaron los grupos de cartas. Al hablar del grupo que está más abajo en el espacio social, el que ella y sus compañeros denominan "los operarios", explica:

Es fácil que a lo mejor la clase los profesionales o la clase media esforzada pueda llegar ahí [a la parte superior de la clasificación], pero es menos fácil que la clase baja, media baja llegue a escalar ahí, es menos probabilidad. Le decíamos porque puede ganarse un premio, pero nunca va a ser igual a ellos.

Para abordar los marcos de referencia en el juego de clasificaciones, distinguimos tres principales: la igualdad de oportunidades, la igualdad de trato y la igualdad de posiciones. Estos aparecen como referentes positivos y negativos durante las interacciones, atendiendo a la dinámica de juicios y contra juicios críticos que ocurren dentro de cada grupo de jugadores, como manifestación de criterios divergentes. Así también, existe una presencia y énfasis distinto de estos marcos de referencia dependiendo de la clase social del grupo de jugadores. Por lo mismo, en los siguientes acápites se revisan tres marcos de referencia de la crítica social; para cada uno se consideran los juicios críticos enunciados por los seis grupos reunidos según clase social de los participantes. El orden de los marcos descritos más adelante corresponde a la frecuencia con que aparecen en las críticas de grupos.

\subsubsection{Igualdad de oportunidades: "se nota que el esfuerzo de él ha valido más que los otros"}

La igualdad de oportunidades es, sin lugar a dudas, el marco de referencia predominante en la crítica social de todos los grupos. Se trata de un ideal que va de la mano con la meritocracia como principio que ordena - o, más bien, que debería ordenar- la sociedad. La crítica social basada en estos criterios lleva a que algunos jugadores juzguen a quienes no han alcanzado posiciones sociales que provean cierta comodidad material como los culpables de tal situación, a la vez que valoran especialmente todo lo que es percibido como esfuerzo personal. Por su lado, quienes critican la imposibilidad de cambiar la situación de vida, como pasar de una ocupación a otra con mejores condiciones, también están utilizando un marco 
de igualdad de oportunidades, pero en el sentido de la falta de ellas para desarrollar un camino propio, no obstante el esfuerzo que se pueda hacer.

Los jugadores de la clase de servicios baja evidencian el caso de la crítica a quienes están en una posición desventajada por su falta de esfuerzo. Andrea, una relacionadora comercial de 46 años, se refiere a la facilidad para acceder a distintos niveles de estudios en la actualidad: "E incluso, la gran mayoría de ellos puede llegar a ser un profesional universitario. Y ellos, eh, también pueden llegar a ser técnicos, porque ahora se da mucho oportunidad de poder estudiar, de que ellos puedan llegar a ser técnicos", con la aprobación de sus compañeros. A propósito del naipe que representa a un joven universitario con un sueldo que consideran bueno, valoran como un signo de esfuerzo el que haya logrado completar ese nivel de estudios, pese a que reside en San Ramón, una comuna del sector sur de Santiago donde, en general, se encuentran personas de menores recursos. Marcelo, un contador auditor, resalta que dadas estas características el joven "tiene un futuro prometedor". De hecho, los jugadores marcan una diferencia con otra carta de un periodista de similar sueldo, pero de mayor edad. Andrea indica "él es un hombre grande ya [el periodista] y él es un joven y ganan exactamente lo mismo. O sea, él tiene más posibilidades de ganar mucho más". Silvana y Nadia repiten, una después de la otra, "Mucho más", agregando la primera "y él no [el periodista]. Buena observación esa". La primera trabaja como administrativa de un cementerio y la segunda también es contadora. Para los jugadores mencionados, el personaje joven representado en el naipe tiene, entonces, mejores condiciones para aprovechar las oportunidades que están disponibles para desarrollar su carrera laboral.

El mismo grupo da cuenta de su aprecio por las trayectorias que parecen de esfuerzo relacionado con el trabajo, a diferencia del naipe anterior, seleccionado por su posibilidad de estudiar. Marcelo explica que eligieron a una representante del grupo social más bajo que construyeron con los naipes "porque lava ropa ajena, vale decir, de una u otra manera está buscando salir adelante [...] No contando con muchas oportunidades, pero de alguna manera lo hace". Andrea asiente al escucharlo. Marcelo prosigue con otro grupo de naipes: "Y aquí pusimos los esforzados, porque, eh, terminaron su enseñanza media completa, eh, pero, igual tienen que redoblar sus esfuerzos para poder sobrevivir en estos tiempos de tanta exigencia 
po"”. En otro momento, Andrea describe cómo agruparon a los naipes según el tipo de educación que tuvieron los personajes. Sobre el grupo de técnicos enfatiza:

Ellos tienen un tema en común que técnicos esforzados, como decía él, el esfuerzo solamente ser técnico y aquí hay un técnico que mira donde llegó y mira lo que está ganando, por eso lo pusimos [como representante del grupo]; tiene, le miramos hasta el rostro, que se ve como simpático, puede guiar el grupo. Por eso lo pusimos ahí.

De tal manera, se entiende que quienes funcionan como líderes o representantes son personas que han forjado su éxito a través del esfuerzo personal, a la vez que detrás de esta valoración positiva del esfuerzo reside una crítica a quienes no se desarrollan al mismo nivel, en tanto no han hecho lo necesario para alcanzar el éxito. Cuando destacan al representante de los técnicos, Andrea resalta como indicativo de su éxito el sueldo similar o superior al de varios profesionales y Nadia lo resume señalando "se destacó por sus capacidades". En consonancia con lo que Araujo y Martucelli (2014) han descrito como una forma de individuación para el caso chileno, serían las habilidades personales las que se evalúan como decisivas para aprovechar las oportunidades disponibles. Las críticas descritas de la clase de servicios baja se enmarcan en los juicios de realidad, ya que constantemente buscan reafirmar un fundamento meritocrático de la realidad.

La crítica a la imposibilidad de construir un camino propio, es decir, en el sentido negativo de la desigualdad de oportunidades, es clara en el juego de la clase social de servicios alta. Hacia el final del juego, Carolina, una ingeniera de 32 años, realiza una evaluación general sobre cómo vieron el espacio social con su grupo. Menciona la existencia de una clase alta, una baja y dos clases intermedias, añadiendo: "Y la baja nunca accede a la alta". Vicente,de profesión abogado, agrega con un movimiento de cabeza: "Y viceversa". Carolina prosigue diciendo que las clases medias, si bien pueden ascender o descender, pueden hacerlo sólo dentro de un rango limitado. Mónica, otra abogada que también trabaja como corredora de propiedades, interviene reforzando esa posición y apunta el mazo con las cartas de las posiciones más bajas -que bautizaron como "plomo"- y luego lleva sus manos hacia el mazo de las posiciones altas -que llamaron "oro" -: "Para que estos lleguen acá, faltan como un millón de generaciones". Carolina agrega un largo "no", a modo de asentimiento, y Ana interviene: “Qué pena, pero es así”. La interacción sigue con el juicio de realidad de Carolina: 
"Y es como está distribuida la riqueza en este país, cachai". Mónica concuerda con este juicio y hace una descripción muy clara de cómo concibe la reproducción de la desigualdad de oportunidades: 'La temporera pa' picar pickle va a seguir siendo temporera pa' picar pickle, y la sobrina y la nieta va a seguir siendo temporera pa' picar pickle. Y años más va a ser profesora de educación básica, si es que". Carolina retoma la imagen construida: "Y el médico seguramente el papá fue médico, o viene de raíces así, de apellido". Mónica, expresando un total acuerdo, afirma "exacto".

Frente a la crítica social en la interacción descrita, Galo disiente mirando a Ana: "No, toda mi familia son profesores, todos, todos, todos. La última generación de nosotros salieron los ingenieros, los veterinarios". Carolina lo insta a que no se lo tome como algo personal, pues están hablando de generalizaciones. Galo, bajando la intensidad de su voz replica un brusco "no, si estaba hablando con ella", apuntando a Mónica. A su vez, Carolina con un tono de ofendida responde: "ya, está bien, no me meto, me quedó claro". En definitiva, dentro del mismo marco de referencia de igualdad de oportunidades, se observan dos evaluaciones distintas de la realidad social. Por una parte, Carolina, Mónica y Ana consideran que existen serias trabas para desarrollarse bajo oportunidades similares -igualdad que consideran deseable- y, por otra parte, Galo expresa la existencia de oportunidades para desarrollarse en la medida del esfuerzo de cada persona. Las primeras desarrollan su crítica en la línea de un juicio de realidad, mientras que el segundo lo hace hablando desde su experiencia familiar, orientándola desde un juicio existencial.

Por su parte, el grupo de trabajadores manuales muestra que la igualdad de oportunidades es un marco de referencia en las dos formas que hemos revisado: crítica a la falta de posibilidades de desarrollo para ciertos grupos sociales y crítica al no esfuerzo, pese a la existencia de las mismas. El caso de la crítica al abuso del capital social para conseguir posiciones, como empleos, es común para develar la falta de oportunidades. Hacer esto, también conocido coloquialmente como usar "pitutos" (Barozet, 2006), se percibe como un hecho injusto, en tanto supone el uso de un recurso que no todos poseen, el favor de cercanos capaces de interceder por uno, y que se considera como una vía ilegítima para conseguir empleo. Al ver la carta que representa a una vicepresidenta de una empresa con uno de los sueldos más altos del set de cartas, Pamela, una trabajadora de casa particular de 41 años, 
indica que "ella ya está con el pituto, viene con una cartita bajo la manga", a lo que Nadia, una auxiliar de aseo de 43 años, repite: "Bajo la manga". Pamela, especulando, continúa: "se puede decir que su papá era amigo del gerente y por ahí hicieron el pituto, típico que se da aquí, entonces ella ya tiene su, su vida segura”.

Las críticas de Nadia son provocativas para Pedro, un maestro pintor de 38 años que no está de acuerdo con que existe una fuerte desigualdad de oportunidades. Después de escuchar atentamente la apreciación de Nadia y Pamela sobre la dificultad de relacionarse entre personas de condiciones sociales distintas, replica exaltado:

No es que [...] Yo estoy cansado de seguir retándola -haciendo reír a algunos participantes-, le he dicho toda la mañana; ¿Por qué no [se pueden relacionar personajes de condiciones muy distintas]? Si uno le enseñan desde chico educación, lo que te contaba ella...dale con que ella tiene plata... no po.

Ante esta intervención, Nadia contesta: "Esta señora puede tener, puede hablar, pero la forma, la educación, o sea, la forma del trato, de repente es diferente". Pedro, insistiendo, agrega: “Por qué el trato es diferente si...?”. Nadia, interrumpiendo, aclara: “El trato no es diferente, si no tu forma de...tu forma de relacionarte, tu forma de hablar, tu forma de expresarte es diferente a ella". Mostrando cierta indignación y dando cuenta de que le cuesta compartir e incluso comprender el marco de evaluación que Pamela y Nadia están usando, Pedro vuelve a intervenir: “¿Por qué si puedo hablar con base...? ¿Qué diferencia tiene?”. Esta última le responde: "no, si usted puede hablar con base, no, usted puede hablar con la base que usted quiera, pero es su forma de expresarse, su forma de hablar". Pedro, todavía con una actitud de indignación, ahora utiliza un juicio basado en su experiencia: "Yo he hablado con gente de, oye, andan así [hace un gesto mirando hacia adelante mientras sube y junta las manos] y yo les proyecto cosas que son...”. Esta vez Pamela lo interpela: "Es que toda la gente, no son igual que usted po'. Yo no soy igual que usted po'. A mí me cuesta llegar aquí po [apuntando a un naipe del grupo más alto que formaron]". Pedro interviene "ah bueno, eso es problema tuyo". Pamela sigue "Porque yo no tengo la misma...", Pedro la interrumpe "no es que no tenga, es que no hace el esfuerzo" y ella termina la frase "la misma manera de hablar que usted po’ señor”. Pedro detiene el rápido ritmo de los intercambios con un “iperdón?” que suena algo grave y ofendido. Finalmente, le dice a la trabajadora de casa particular: "Aprenda 
porque somos todos iguales". De tal manera, culpa a Pamela por no haber hecho el esfuerzo de desarrollar habilidades para relacionarse con personas que poseen mayores recursos, lo que él considera posible y responsabilidad de cada uno. Según Pedro, ella desaprovecharía las oportunidades que están disponibles para todos. En la evaluación de Pedro prevalecen, entonces, juicios de carácter existencial, en tanto se encuentran fundados en su experiencia. Las participantes que discuten con él, en cambio, apelan a la falta de eficacia de la igualdad de oportunidades, de manera que formulan juicios de realidad.

Pasando a otro grupo, los jugadores de la clase social de trabajadores independientes hacen una mezcla de ambas formas de la igualdad de oportunidades como marco de referencia. Por una parte, critican a quienes están en posiciones privilegiadas en la sociedad, en tanto convierten su ventaja en un mecanismo de reproducción social. Loreto -contadora independiente y profesora de clases de baile de 40 años- indica cómo los exitosos "nacieron así, que eso es lo otro. Que nosotros decimos que ese tipo de gente, nace en cuna de oro, entonces...". Raúl de 54 años, complementando, agrega "nace en una buena vida", seguido por José -un comerciante de longanizas de 57 años- que señala que "les da lo mismo". Es decir, desde la perspectiva de estos participantes, se trata de personas que no están sometidas a una dinámica centrada en el esfuerzo personal. Esta última es complementaria con la visión de los jugadores sobre cómo opera la sociedad, coincidiendo en que, si bien ocurre lo mencionado con las posiciones de los más privilegiados, también es posible tener éxito a través del esfuerzo.

Raúl interroga al grupo: “Ahora si hilamos más fino, esta gente, la más modesta, ¿puede llegar allá [a la parte superior]?”. Loreto e Isabel -dueña de casa y vendedora de productos por catálogo de 64 años- responden respectivamente que "puede aspirar a llegar, pero...", "tienen que ser gente que quiera superarse mucho, para estudiar y sacrificarse”. José añade que existe un componente etario relevante, ya que el ser joven provee de mayores posibilidades de conseguir la superación. Leopoldo, un comerciante de 42 años, duda sobre esta retórica del esfuerzo: “Ahí encuentro que el factor suerte juega, a ese nivel, juega”. José replica a esto: "el factor suerte.... bueno, pero la suerte se la hace uno", a lo que Leopoldo insiste en que la suerte tiene un papel en la trayectoria de cada persona, por ejemplo si alguien logra llegar a trabajar al rubro de la gran minería, donde los sueldos son superiores. Frente a 
ese ejemplo, José acota que ahí son importantes los contactos. Asimismo, Isabel menciona que hay posiciones privilegiadas que vienen del esfuerzo, como los médicos: "Pero los médicos no nacieron ahí, porque hay gente de mucho esfuerzo que ahora está ganando esa plata". Consecuentemente, Loreto considera que no siempre es así el caso de los médicos, pues seguir esa carrera costosa y extensa requiere eventualmente tener una familia que provea las condiciones para seguir tal formación. Añade que la clase media difiere de ese modelo, en tanto logra llegar a su posición gracias al propio esfuerzo, lo que respalda Isabel diciendo: "claro, a rebuscárselas por todos lados". Un caso ilustrativo de este marco de referencia es el análisis que los jugadores hacen de un naipe donde se representa un hombre respecto al cual Isabel señala: “el administrador de restaurant, él no tiene estudios, pero es exitoso, está ganando lo mismo que un profesional”, seguida por el juicio de Loreto:

Claro, si nosotros también nos fijamos. Como también nosotros vimos la clase media esforzada, de un millón, de 750 a 1.500 .000 [pesos]. Por ejemplo a él lo destacamos a él porque solamente tiene estudios técnicos, y gana igual o más que los otros que tienen estudios universitarios. Entonces se nota que el esfuerzo de él ha valido más que los otros.

Los trabajadores de rutinas no manuales baja también expresan sus críticas principalmente desde la igualdad de oportunidades. Tematizan la posición de las dueñas de casa, en particular. Álvaro - un administrativo de una organización privada de salud de 40 añosexplica cómo agruparon los naipes, dejando un conjunto con las dueñas de casa. Sobre este, apunta: "Y este nos costó harto y nos hizo llorar, que es el de las dueñas de casa". Luego Mara -camarera de 48 años- agrega “es que tienen pocas oportunidades”. Álvaro aclara:

No, no tienen pocas oportunidades. Nosotros lo pensamos de otra manera. Porque si tú te fijas, ella es universitaria, pero es dueña de casa. Tiene oportunidades cuando ella quiera salir a trabajar. Las tiene. Pero ella se postergó como mujer por su familia, por el amor.

Es el sacrificio de las dueñas de casa lo que él valora. En cambio, Fernando - un técnico en instalaciones sanitarias y junior de 40 años- discrepa abiertamente con el criterio que usó Álvaro. Explicando el criterio que usaron para agrupar las cartas, señala que valoraron especialmente a quienes son trabajadores independientes, ya que no tienen que trabajar apatronados. De esta manera, cuenta que "por ejemplo, nosotros dividimos en tres las cartas que nos pusieron en la mesa con respecto a los profesionales, lo técnico y dueña de casa, o 
gente que no tiene oportunidades", manteniendo la idea de que las dueñas de casa quedan atrás en términos de una eventual igualdad de oportunidades. Continúa explayándose sobre cómo clasificaron a las personas representadas en los naipes:

Los profesionales pueden aspirar más pueden ser independientes o dependientes. Es problema de ellos, porque como profesional tú tienes un campo mucho más, la parte técnica. Ahora, pa' que decirte las dueñas de casa o la gente que no tiene enseñanza media, ni básica completa, que están más limitados con respecto a los técnicos, y eso también hay gente que tiene básica y a lo mejor tiene la posibilidad mental de ganar más que un profesional, eso está dado, pero la mayoría, el 90\% se queda estancado por equis cantidad de problemas, ya sean los hijos, la discriminación, el machismo, caleta de cosas po.

La igualdad de oportunidades es coartada tanto por los requerimientos cotidianos o bien por aspectos más estructurales, impidiendo lo que sería un desenvolvimiento más justo. Más adelante, Álvaro termina compartiendo la argumentación de Fernando y considera que efectivamente existe un valor en trabajar de manera independiente. Según él, también es efectivo que la falta de oportunidades limita las posibilidades de desarrollo personal, porque uno de los problemas de la clase media es que "somos los que nos da miedo dar el paso a ser independientes, a ser propio, por falta de educación, por falta de oportunidades, por falta de dinero, por lo que sea". De todas formas, al escuchar la mención que hace Fernando para terminar su comentario, respecto a que las dueñas de casa son quienes pueden optar por trabajar con un jefe o como independientes, Mara expresa: "No es por discriminarla, pero hay gente mediocre también. Que no quiere avanzar". Álvaro coincide con ella -“Sí, eso en todos lados" - y Boris también interviene - "Hay en todos los estratos sociales" -. Mara termina su comentario señalando: "bueno, no voy a decir una palabra, pero son gente que no quiere avanzar, gente mediocre que le gusta estar ahí nomás, no esforzarse más y superarse". De este modo, los jugadores coinciden, por una parte, en la crítica de que existen quienes no tienen éxito en la vida por su propia mediocridad y, por la otra, en la creencia de que ciertas personas se enfrentan a obstáculos que atentan contra una igual posibilidad de desarrollarse, principalmente en el estrato que denominan como la clase media. Esta línea de crítica es muy común en las distintas clases sociales, utilizando principalmente juicios de realidad y 
atribuyendo vivencias indeseables, como un mal pasar material, a la agencia de los mismos, dejando en un segundo plano aspectos estructurales o culturales.

En el caso de los jugadores de la clase de rutinas no manuales alta, el marco de la igualdad de oportunidades se expresa en las críticas principalmente como el desaprovechamiento de la existencia de posibilidades efectivas para desarrollarse, al menos en relación a décadas anteriores. Catalina -funcionaria municipal de 40 años- problematiza lo que considera como excusas que dan algunas personas con dificultades en la vida:

Entonces va a decir todo el rato 'es que tu viví ahí po', 'es que a ti te los pagaron', ‘yo tengo que trabajar pa' pagármelo', no sé po' y buscan cómo, la excusa, no sé cómo decirlo, pero... es que hay excusas ahora pa' estudiar y no estudiar. Ahora no es como antes, antes era difícil estudiar.

Su intervención es respaldada por otros jugadores. Por ejemplo, Demeterio -un técnico en armado de computadores de 55 años- dice: "Ahora no hay excusa po", haciendo que Catalina prosiga - “icierto? -, que antes era tan difícil po’, no habían, no habían becas, no había mucho lugar donde te pudieran ayudar pa' llegar”. Ahora Martín, un contador de una gran empresa, refuerza la posición: "hoy en día tienen más oportunidad que nadie [...] Tienen más oportunidades para todos, si por eso se dice, el que quiere trabajar, hoy día trabaja”, lo que a su vez complementa Catalina, haciendo ver la indignación que producen quienes desperdician las oportunidades:

Y el que quiere estudiar [...] Pucha, están los dos por uno, les dan hasta los cuadernos a los cabros, entonces cuando veí a un cabro que no quiere estudiar, que no quiere [...] que prefiere estar en la esquina, o que prefiere ir a ganarse un par de lucas, da rabia eso.

El marco contextual de la igualdad de oportunidades que predomina en los juicios de este grupo sirve de trasfondo a las críticas hacia la falta de esfuerzo personal y al desaprovechamiento de la mayor presencia de oportunidades en relación al pasado.

La descripción realizada da cuenta de juicios críticos, mayormente de juicios de realidad, donde se deslindan dos dimensiones de la crítica desde el marco de referencia de la igualdad de oportunidades. Por un lado, se denuncian las barreras sociales al ascenso social basado en el esfuerzo individual y, por otra parte, se critica la falta de esfuerzo individual de quienes se 
encuentran principalmente en posiciones desaventajadas. Por lo tanto, predomina la crítica reformista propuesta por Boltanski, al no ponerse en cuestión las reglas del juego que han llevado a esas posiciones desaventajadas (Bourdieu, 1999) o bien al basar sus críticas en el principio contextual de meritocracia, esto es, el de merecimiento según el esfuerzo individual. Además, desde la perspectiva de los participantes, los factores estructurales o culturales son relegados a un segundo plano. Desde la crítica ordinaria, prima la agencia como motor de cambio de la realidad social, incluso en relación con los obstáculos al ascenso social, como los "apitutados", que tienden a identificarse como problemas a nivel individual. Siguiendo el enfoque $\mathrm{M} / \mathrm{M}$, esto tiene implicancias sobre cómo desde la agencia se valoran los otros componentes de la realidad social para transformarla. Sucintamente, los resultados del análisis de este marco según clases sociales se recapitulan a continuación.

La clase social con mayores recursos en la estructura social considerada en este análisis, la de servicios alta, denuncia la falta de igualdad de oportunidades. Sus juicios críticos destacan las barreras a la movilidad social, especialmente las impuestas por los grupos más ricos de la sociedad, lo que sería la elite económica. De tal manera, denuncian los obstáculos sociales que bloquean el ascenso de su propio grupo social, en tanto son quienes están más cerca de la parte superior de la estructura social. Se trata de críticas que apuntan a la necesidad de hacer cumplir lo que consideran un fundamento del funcionamiento social, la meritocracia. En este sentido, se trata de juicios de realidad.

Las críticas de la clase de servicios baja también se enmarcan en los juicios de realidad, ya que constantemente buscan reafirmar un fundamento meritocrático de la sociedad. En particular, sus críticas se focalizan en la denuncia de la mediocridad o falta de esfuerzo de personas en posiciones desaventajadas. Estos juicios críticos asumen que en la sociedad existen posibilidades, sólo que algunos no las aprovechan por holgazanería o falta de iniciativa. Como contracara, valoran el esfuerzo, por ejemplo, de alguien con una labor con baja remuneración y prestigio en Chile: una mujer dedicada a lavar ropa. Este trabajo es positivamente evaluado en tanto se percibe como un trabajo físicamente demandante que, por consiguiente, requiere alto esfuerzo. Cabe destacar que en principio es contradictorio respaldar la igualdad de oportunidades como fundamento que sostiene el ascenso social a través del mérito individual y valorar el perfil de alguien que se esfuerza mucho, no obstante 
mantiene una baja posición relativa en la estructura social. Como se revisa más adelante, los individuos elaboran juicios críticos que pueden corresponder a distintos marcos. En algunos casos, los marcos de referencia son lógicamente inconsistentes, como la igualdad de oportunidades y de posiciones (Dubet, 2013), pero operan conjuntamente en la práctica.

Los trabajadores independientes al interactuar exhiben ambas caras de la crítica recién expuesta en el marco de la igualdad de oportunidades: denuncian la falta de esfuerzo de quienes no consideran exitoso, así como valoran el esfuerzo por salir adelante. Así, concuerdan en una falta a la igualdad de oportunidades producida por los sectores más altos, particularmente a la dinámica del esfuerzo-éxito que se espera en este marco. Los jugadores de esta clase social formulan juicios de realidad en este caso, al criticar el ascenso social o la mantención de una posición alta sin un debido esfuerzo. Por otra parte, también refrendan el marco de igualdad de oportunidades constatando que en algunos casos la meritocracia sí tiene lugar, tal como debería ser desde su perspectiva. En esta línea, los trabajadores independientes encuentran sustento en el set de naipes para la idea de que el esfuerzo puede llevar al éxito, al destacar el naipe de un hombre con ingresos altos y sin educación universitaria.

La clase de rutinas no manuales alta enfatiza la crítica hacia el desperdicio de oportunidades disponibles por el contexto chileno actual, por lo que también los juicios de realidad son los que prevalecen en sus denuncias. El marco de igualdad de oportunidades, en este caso, genera una crítica generacional. Desde la perspectiva de los jugadores de esta clase social, el desarrollo laboral y educacional se considera más llevadero que en décadas anteriores y, aun así, existen quienes no se esfuerzan.

La clase de rutinas no manuales baja elabora juicios de realidad desde la igualdad de oportunidades, pues evalúan positivamente la posibilidad de ascenso social según los méritos y el esfuerzo personal. A su vez, evidencian que existen barreras estructurales a la igualdad de oportunidades que afectan especialmente a los sectores de las clases medias, lo que constituye un problema desde su perspectiva. También entre los trabajadores de rutinas no manuales baja se expresan juicios de realidad que critican la falta de esfuerzo de algunas personas, cuestión que justifica su estancamiento social. 
Finalmente, la clase de trabajadores manuales enuncia críticas correspondientes a ambas dimensiones identificadas en este marco de referencia. La discusión de Pedro con Pamela y Nadia las ilustra. Las últimas convergen en una crítica hacia el aprovechamiento indebido de recursos sociales de personas en cargos altos, lo que se denomina pituto en Chile. De esta manera, denuncian las faltas al modelo meritocrático que promete éxito a través del esfuerzo individual, en la línea de los juicios de realidad de otras clases. En contraste, Pedro defiende que las desigualdades de oportunidades no son agudas, sino que existen suficientes. Las críticas de él -y de varios otros jugadores- apuntan más bien de problemas en el trato, como abordamos en el siguiente acápite.

En definitiva, se observa que el marco de igualdad de oportunidades es extensivo en todas las clases sociales analizadas. Este marco de referencia toma principalmente dos formas: una crítica a los obstáculos a la meritocracia, por lo tanto, se expresa como juicios de realidad; y una crítica a la falta de esfuerzo personal de quienes están en posiciones desaventajadas, lo que generalmente también es expresado en la forma de juicios de realidad. Además, los hallazgos sugieren que las críticas enunciadas se nutren de manera importante de la posición social que ocupan. La clase de servicios alta critica las barreras producidas por los grupos más altos de la sociedad, así como los trabajadores de rutinas no manuales bajas denuncian las barreras impuestas a las clases medias. En otras palabras, denuncian las barreras impuestas a sus propios grupos.

\subsubsection{Igualdad de trato: "pero la sociedad no los trata a todos iguales"}

Un marco de referencia recurrente es el que se refiere a la igualdad de trato, vale decir, aquellos criterios que apuntan a lo indebido de discriminaciones arbitrarias, humillaciones o descortesías en el intercambio cotidiano. Las críticas elaboradas dentro de este marco de referencia se dirigen más bien hacia los procedimientos, antes que a las razones que puedan subyacer a tales procedimientos. Se trata, entonces, de criticar el hecho mismo de que una persona sea discriminada por ser indígena o mujer, por ejemplo, antes que apuntar a los motivos que han llevado a esa situación o a los contenidos políticos y morales de la discriminación.

Este marco de referencia tiene una presencia mayor en la crítica social del grupo de trabajadores manuales, en comparación al resto de los grupos. Siguiendo la dinámica 
mencionada entre Pedro (el maestro pintor), Nadia (la auxiliar de aseo) y Pamela (la asesora del hogar), el maestro pintor sobre las posibilidades de relacionarse entre los grupos más altos y más bajos, esta última jugadora, mientras posa sus manos sobre los mazos de los conjuntos más bajos que construyeron, explica que "estas dos clases, estas dos clasificaciones [...] cuesta llegar aquí", llevando sus manos hacia el mazo que representa al grupo más alto. En la misma línea, Nadia agrega: "No, es que ellos te miran hasta cómo tú hablas, cómo te expresas, cómo te sientas, como..." -“cómo te vistes", interviene Pamela- "cómo te vistes. Ellos, ellos no te miran así a la cara, sino que te miran así, de pies a cabeza”, continúa la primera. Frente a esto, Pedro las interroga: "¿Y qué pasa si tú andai bien vestido como ellos?". Nadia le responde: "No, no importa, igual...". Entonces vuelve a ser interpelada: “¿Y modulas bien? ¿Por qué no?”. Nadia concede parcialmente la posición de Pedro, aunque insiste en que sigue habiendo una distancia insalvable: "Ah claro, ahí, ahí no te, pero después tú empezai a hablar de tu vida, y ya como que ahí ya estai...”. Hernando interviene siguiendo la posición de la crítica de Pamela y Nadia: “está muy claro lo que pasa en Chicureo [un sector de Santiago con condominios donde residen ricos]; la empleada no puede andar en la calle". Se refiere a un episodio que apareció varios días en los noticieros en enero de 2012, donde una residente del condominio en una entrevista enuncia una frase relativa a lo inadecuado de que obreros y empleadas domésticas transiten por las calles de su condominio cuando se encuentran niños jugando.

Frente a esa última intervención de Hernando, Pedro aclara que "ahí estamos hablando ya de discriminación, po"”. El maestro pintor evidencia un marco de referencia que tiene una profunda base en la creencia de que todos deberían ser iguales en el plano de las relaciones sociales, más allá de diferencias en la cantidad de dinero o recursos de otro tipo que se posean. En definitiva, también reconoce el uso de un marco de referencia donde la igualdad de trato es un horizonte normativo. Adicionalmente, la interacción que termina con el reconocimiento por parte de Pedro de que sería discriminación prohibirle transitar por la calle a empleadas ha sido producto de un proceso de intercambios que lo motivaron a desarrollar su posición original, estableciendo un matiz. De tal forma, la interacción entre los participantes genera una mayor elaboración y, en ese sentido, sugiere un mayor nivel de reflexividad de Pedro. Este matiz, además, se enuncia como una crítica bajo la forma de juicio de realidad, considerando los principios de igualdad de trato respaldados por Pedro. 
Para explicitar su punto de que uno "se puede relacionar con cualquier persona", el maestro pintor narra una experiencia vivida:

Oye, mira, de hecho yo voy a contarte una anécdota: cuando vino The Wall ahí en Espacio Riesco, ahí las medias camionetas, ¿sabí qué me gritaba la gente pa’ salir? “¡Córrete indio!”, así ah, y yo estaba de los primeros, no dejé pasar a nadie, “¿Seguro que vo’ veni de...? ¿ah? ¿cachai?” Y no tenía ni educación la gente, ella tuvo que bajarse a decirme... “¿Por qué me decí indio? ¿...que vení de otra raza tú? Si cuando llegaste acá éramos todos iguales", al menos yo siempre digo que ante Dios somos todos iguales [....] Yo pa mí, ante Dios somos todos iguales.

La narración de Pedro da cuenta, en primer lugar, de una crítica elaborada a través de un juicio de verdad; naturaliza su principio de justicia sobre la igualdad de trato argumentado desde un criterio $a b$ origine. Según este criterio todos deben ser tratados de igual forma pues comparten el mismo origen, que sería Dios, según el maestro pintor. Se trata de un juicio de verdad ya que constituye una construcción que hace caso omiso a lo que ocurre en la realidad, como se describe en la misma anécdota al desconocer el maltrato sufrido, y sostiene la creencia normativa de que todos deberían ser tratados de igual forma, asumiendo que eso ocurre en la práctica.

La historia, con su crítica a la discriminación, despierta reacciones en varios participantes y Pamela contesta: "Pero es que pa' ti po, pero la sociedad no los trata a todos iguales". Pedro finalmente increpa la posición que han sostenido Pamela y otros: "Es que si tú hablai así, hace rato que tú decí 'los que tienen plata', yo pa mí son todos iguales”. De manera que, aunque Pedro haya vivido una situación de discriminación -como relata en su anécdota-, considera que existe un trato en términos de igualdad con cualquier persona.

De tal manera, si bien existe un desacuerdo acerca de la posibilidad de relacionarse entre sujetos de distintas condiciones sociales, ambas partes critican desde un marco de la igualdad de trato, según el que es inaceptable la discriminación y el menosprecio entre personas. Por lo mismo, más adelante Pedro cuestiona la creencia de que existen personas "más bajas" o "más altas”. Juan señala que es algo "notorio”, por lo que Pedro le pregunta “¿Pero cómo [lo nota]? ¿Porque uno es indio o negro? ¿Pero cómo?”. Hernando responde “es que...existe”. Pedro acepta esto, replicando rápidamente "No, si hay de todo". "Lamentable...", agrega 
Pamela, a lo que Hernando apunta con un juicio de realidad "Lamentablemente existe [...] Aunque algunos no lo queramos, aunque algunos no lo queramos”. Finalmente, Hernando manifiesta que "es la realidad. Entonces, existe, si la persona...la más baja...existe, pero lo que hay que, no hay que, lo que hay que hacer es no discriminarla, si no tratar de ayudarla", lo que recibe la venia de Juan, quien repite la última palabra afirmativamente -"ayudarla"-. En definitiva, hay una evaluación negativa compartida sobre la discriminación que es formulada bajo la forma de juicio de realidad, a la vez que se apela a la necesidad de conseguir una igualdad en el trato.

Respecto al surgimiento de este marco de referencia en el grupo de trabajadores manuales, en tanto es comparativamente la clase social de jugadores que posee las peores condiciones socioeconómicas, es indicativa la experiencia que Nadia narra hacia el final del juego. Cuenta una historia que vivió en su trabajo, que consiste en hacer el aseo en una comunidad religiosa donde habitan monjas. Explica que un día sacó una llave para entrar a limpiar una habitación:

Estaba haciendo las cosas yo, cuando de repente, me ve que estoy adentro [una religiosa extranjera] y me dice ‘¿tú qué haces aquí adentro?’, yo le dije ‘estoy limpiando’, ‘de dónde sacaste tú la llave? ¿Quién te dio permiso a ti pa’ sacar la llave? ¿Por qué la sacaste?' [...] Y sabes tú que yo me sentí pero horrible, horrible, horrible. Y yo dije, 'nunca, nunca en mi vida me había sentido tan humillada por una religiosa'. Me discriminaron, siendo que yo las siento que ellas están ahí. A ver, las religiosas cuando hacen sus votos de humildad y de pobreza, porque yo le dije después a la Superiora: 'yo no veo los votos de humildad de esta religiosa, de pobreza tampoco porque usted sabe cómo viven ustedes'. Le dije 'yo soy una persona que no me voy a robar un papel, porque en esta oficina no hay dinero, y si hubiera dinero, tampoco lo tocaría'. Entonces, yo me sentí mal que una persona que yo considero que está para ayudarme a mí, porque en las religiosas se supone que uno busca ayuda, que las religiosas la apoyen, le expliquen o le digan cómo es la vida, sentirse como, eh [...] me sentí muy mal porque yo sentí que, eh, me estaban tratando de ladrona. En mí, en la parte donde yo llegaba, como si fuera mi casa [...] Ese día, ese día yo dije 'nunca, esta no es mi casa, yo aquí entro y salgo', y a mí cuando me dicen las hermanas, porque las hermanas te abrazan y te dicen, eh, no se po', 'cómo tú eres parte de la comunidad', yo no soy parte de la comunidad, o sea, yo aquí les 
vengo a trabajar, porque me sentí discriminada, y dije, de siempre dije, yo le dije a mis hijos 'me hicieron esto, esto otro. Yo no quiero que ustedes nunca, o sea, yo quiero que ustedes estudien, estudien, estudien para que nunca pasen, ni siquiera así un poquito, de la humillación que yo sentí'.

Aunque no pueda concluirse a partir de una historia en particular cómo se desarrolla un marco de referencia de la crítica, la experiencia personal contada por Nadia ilustra puntos muy interesantes. En primer lugar, se elabora desde un juicio existencial, al fundar su crítica desde la experiencia. Por una parte, evidencia cómo quienes están en una posición social inferior se ven más expuestos a ser discriminados, ya sea como primeros sospechosos o simplemente como sospechosos, en general. Luego, se muestra como una crítica fundada también en juicios de realidad en la medida que este tipo de maltrato no se condice con lo que se espera para el contexto actual en términos de igualdad de trato como horizonte normativo, tal como lo expresaba Pedro. Así también, da cuenta de la profunda sensación de humillación y ofensa que una experiencia de discriminación puede provocar, en la línea de los juicios existenciales. Por último, muestra cómo se transfiere esta historia - y eventualmente el marco de referencia mismo, en tanto horizonte normativo-desde la madre a sus hijos; considerando que los hijos también percibirán la emoción de fuerte desazón que una vivencia así provocó en su madre.

Otros grupos de jugadores también utilizan la igualdad de trato como marco de referencia de su crítica social, aunque en menor medida. Los trabajadores de la clase de rutinas no manuales alta que participan en el juego tematizan la posibilidad de que los distintos grupos de personas representadas en los naipes se relacionen. Martín manifiesta que se cuestionó el mismo hecho de separar a los naipes en distintos grupos: "Cuando comenzamos, yo les dije a ellos, que podríamos hacer un solo grupo... hacemos un solo grupo nomás con todas las personas [...] Porque ahí ya nos pusimos a discriminar este gana esto, este gana esto otro". De esta manera, valora positivamente el tratar de manera igualitaria a las personas, al punto de que vaciló respecto a separar las cartas por evitar una eventual discriminación. Demeterio aborda la cuestión de las relaciones entre distintas personas de manera tajante, siguiendo la línea en que lo hizo Pedro en el grupo anterior: "Claro, yo... si de que somos todos iguales, somos todos iguales. Pero nosotros, ¿actuamos todos iguales?”; pregunta retórica con la que anuncia el juicio de realidad a través del que elabora su crítica, pues no cree que en la práctica 
se trate a todos de forma igual, como se debería hacer según él. Luego, Catalina comenta sobre lo plausible de que personas de distintas profesiones, lugares de residencia e ingresos salariales se puedan relacionar. A propósito de esa intervención, Demeterio cuenta una historia personal:

Por ejemplo, nosotros nos juntamos los, los, todos los del ejército [...] Los que hicimos el servicio militar en el año 73, nos juntamos, todavía nos juntamos todos, un montón, y hay hartos que ganan harta plata. Hay uno que es dueño de una empresa de seguridad, hay varios que tienen harta plata y yo soy de San Ramón, tengo mis cosas, pero no tengo plata.

Catalina, viendo la corroboración de lo que había comentado en la experiencia de Demeterio, señala: "Pero son tus amigos", lo que él afirma: "Y seguimos siendo amigos...y con los del colegio igual”.

La apreciación manifiesta hacia los marcos normativos de igualdad de trato tiene su correlato en algunas críticas que realizan en el grupo. Por ejemplo, cuando Demeterio habla del conjunto de naipes que armaron con quienes consideran "los estancados", por no haber conseguido mejores condiciones de vida pese a tener algunos estudios. Destaca especialmente el naipe que representa a alguien con estudios técnicos y una remuneración de las más bajas entre las cartas. Lautaro replica a modo de contra crítica:

No, entran otras cosas, otras cosas que yo les dije a mis compañeros y que no quiero repetir... entran otras cosas, hay gente que deja montones de currículum en todos lados, pero está la discriminación. Hoy día se da por edad, por apariencia física [...] O por el lugar donde vive.

Clara suscribe esta crítica -"Sí, eso es verdad"-, mientras Demeterio busca matizarla -"Pero no en todos lados, po"”-, abriendo una polémica con Lautaro. Este último sigue: "Entonces les cierran las puertas", frente a lo que Demeterio disiente -"No, no. Usted pesca el diario ahora y sale cualquier cantidad de trabajos [...] y ve a alguien por ahí y le dice 'no, si no encuentro pega', 'no, si no hay pega en ni un lado""-. Lautaro le contesta: "Yo le digo, los discriminan, aunque estemos...”. Esta réplica provoca una inmediata objeción de su interlocutor: "No, no hay tanta discriminación”. Lautaro sigue: "Sí...por la edad, por la edad usted, discriminan mucho a la gente". Ahora Demeterio se expresa en contra de su propia posición: "A mí no me dan pega en ninguna parte, porque tengo cincuenta y cinco años", 
frente a lo que Lautaro indica que "eso se llama discriminación”. En el fondo, se dan cuenta de que sus posturas se refieren a distintos aspectos. Demeterio explica: "Pero si quiero trabajar, tengo pega, pero en lo que yo quiero trabajar, no me van a dar. Pero si quiero ser guardia, puedo ser guardia, hay cualquier cantidad de trabajos por si yo quisiera trabajar". Luego, Lautaro vuelve al caso original del naipe: “Sí, pero él estudió algo po’, entonces eso es lo injusto [...] Entonces es injusto que no pueda trabajar en lo que él estudió", con lo que Demeterio concuerda.

Si bien en ninguna parte del juego se explicaba por qué la persona con educación técnica tiene un bajo sueldo, Lautaro construyó un relato al respecto que, además, generaliza. Se califica de injusto lo que se percibe como discriminaciones de género, lugar de residencia o de edad. Esta forma de la igualdad de trato como marco de referencia tiene una relación estrecha con la forma de la igualdad de oportunidades detrás de las críticas a los obstáculos existentes para desarrollarse con oportunidades equivalentes. De hecho, en un caso como éste operan conjuntamente. La diferencia es más bien de énfasis, según se destaca un aspecto de restricción estructural a la movilidad -un problema que supone el marco de la igualdad de oportunidades- y otro relativo a la discriminación activa a las personas -que se traduce en un problema evaluado a través de la igualdad de trato-.

La presencia de un marco de igualdad de trato en la crítica a las discriminaciones se ilustra también en el grupo de rutinas no manuales baja. Álvaro, administrativo de Isapre, interpela a su compañero Fernando, técnico en instalaciones sanitarias y junior, quien había comentado sobre la imposibilidad de un recolector de basura de cambiar su situación: "El basurero va a ser basurero... porque tiene limitación". Álvaro le responde: "Yo te apoyo que la educación es la parte primordial [...] Pero el hecho que tú digas que una persona está postergada porque es basurero, es re difícil". De tal forma, Álvaro muestra incomodidad con el tono de condena en la crítica de Fernando, basada en la ocupación del personaje del naipe. Según Álvaro existe una desigualdad en el trato de Fernando hacia el personaje representado en el naipe, pues este último supone que el situarse en una particular posición ocupacional baja es un indicador de conformismo y estancamiento. De manera que enuncia una contra crítica hacia el otro participante, a partir de un juicio de realidad que asume la norma del trato igualitario y 
respetuoso entre personas y, por tanto, la no discriminación de alguien por su ocupación particular.

La diferencia que existe entre los marcos de referencia de la crítica, en tanto ideales que sostienen las personas, con las acciones que efectivamente tienen lugar en la realidad social se ilustra con un meta juego que tiene lugar en el grupo de rutinas no manuales baja. Álvaro toma dos cartas que representan a mujeres y se las muestra a Fernando preguntándole: "Por presencia, si tú tienes que contratar una secretaria, ¿cuál de las dos te llevas?’. Rápidamente Fernando responde que "la más joven”, generando la interpelación de Mara: “joye qué eres!, ¿qué tienes contra las mayores?”. De esta forma, ella da cuenta de un marco de referencia de igualdad de trato, refiriéndose a la discriminación etaria. Sólo un momento antes, Fernando había manifestado su respaldo al criterio de no discriminación hacia las mujeres:

Lo que pasa es que por ejemplo la parte en que nosotros tiramos eso, lo que estaba diciendo yo, la parte de dueña de casa, donde la dueña de casa ha terminado la educación media, incluso la universitaria, y por el hecho de ser mamá, el machismo los hijos, la misma sociedad le dice 'quédate en la casa'. Y tiene que quedarse en la casa por años, por años, hasta que de repente se libera, que son los pocos casos.

En principio, Fernando critica la discriminación hacia las dueñas de casa, ya que según él dedicarse a las labores del hogar implica una subyugación y postergación. En una argumentación similar a la contenida en la crítica que Álvaro le realizaba, Fernando critica también con un juicio de realidad la desigualdad en el trato hacia las dueñas de casas, en tanto son estructuralmente obligadas a relegarse al espacio doméstico -“la sociedad le dice..."-; lo que es injusto, pues supone un trato desigual hacia este grupo particular. Sin embargo, luego Fernando discrimina por edad a las mujeres en el juego que le propone Álvaro, lo que es contradictorio con el marco de referencia de igualdad de trato que suscribe.

Al continuar la conversación, Fernando justifica su decisión de seleccionar a la mujer por ser más joven: "Y uno como jefe, yo... Pero si hablemos la realidad". Vale decir, si bien en términos ideales se manifiesta en contra de la discriminación, sabe que en la realidad aquello no opera y, de hecho, él mismo actúa en contra de su propio marco de referencia en el meta juego que le propone Álvaro, según considera que es la forma en que funciona el mundo. En el fondo, como indica Araujo, “el ideal puede participar en las formas de presentación y 
legitimación y, sin embargo, no tener la misma influencia para orientar las conductas o prácticas" (Araujo, 2015, p. 83). De esta manera, cabe distinguir los marcos de referencia de la crítica con lo que efectivamente ocurre en términos de la acción.

Por último, en la clase social de servicios baja también se hace una crítica desde este conjunto de principios. Luciano, un contador auditor de cuarenta años, critica con un juicio de realidad la discriminación que se hace por edad y apariencia al buscar trabajo: “Acá en Chile, todavía, digamos, uno postula a un trabajo y tiene que ir con la fotografía". Alude, entonces, a la discriminación que se produce hacia personas mayores o cuando se privilegia candidatos según su aspecto físico.

A modo de síntesis, se observa que el marco de igualdad de trato es relevante especialmente para la clase social de trabajadores manuales. Se trata de un marco compuesto por principios orientados desde la necesidad de mantener un trato adecuado entre las personas, donde no se discrimine en el trato por aspectos arbitrarios, como la ocupación, el estatus, la edad o la apariencia física. La forma de crítica que prima, como sucedía en el marco de igualdad de oportunidades, es la de los juicios de realidad. Esto pues se asume el principio normativo del trato igualitario y respetuoso como criterio de evaluación. Desde ahí, se realizan críticas a distintas situaciones de la realidad social donde se constata la desviación de este principio, tales como la desconfianza y el maltrato a trabajadores no calificados, la discriminación hacia las dueñas de casa y los basureros, etc. La anécdota de discriminación narrada por Pedro, el maestro pintor, es ilustrativa al respecto, pues da cuenta de un criterio normativo de igualdad de trato y constata la transgresión a este. No obstante, también es excepcional en la medida que Pedro critica a sus compañeros desde un juicio de verdad, el cual asume que en la práctica opera el criterio de igualdad de trato en tanto "Dios nos hizo a todos iguales". Entre los jugadores de esta clase social también se observa un indicio interesante de reflexividad, posibilitado por la interacción comunicativa del grupo que lleva a Pedro a reconsiderar su punto de vista y matizarlo, lo que se expresa en la enunciación de una crítica con forma de juicio de realidad.

El resto de los grupos donde se encuentran críticas a partir del marco de igualdad de trato corresponde a los de rutinas no manuales baja y alta, así como al de la clase de servicios baja. Entre estos la aparición del marco de igualdad de trato, comparado con en la clase de 
trabajadores manuales, es más bien marginal. En términos del marco de referencia, Demeterio y Martín -jugadores de la clase de rutinas no manuales alta-, evidencian con claridad la idea normativa de que todos deben ser tratados de igual forma. El primero también manifiesta críticamente el desfase que existe entre el ideal normativo de la igualdad de trato como marco de referencia, frente a lo que ocurre en la realidad al respecto. Por lo tanto, elabora una crítica principalmente a través de juicios de realidad. Si bien se observa un desacuerdo entre los participantes de esta clase social sobre el grado de discriminación que existe hacia distintos grupos en el espacio social chileno, es extendido y manifiesto el acuerdo sobre lo injusto de la discriminación en el trato. Además, los grupos de rutinas no manuales alta y de servicios baja convergen en la crítica a la discriminación en el mercado laboral, donde se considera injusto el trato desigual que reciben candidatos según su edad.

Por otra parte, las críticas que surgen desde el marco de igualdad de trato de la clase de rutinas no manuales baja ilustran la relevancia de distinguir los marcos de referencia que se suscriben de los principios de justicia que operan en la práctica misma. Esto se observa en el meta juego en el que participa Fernando, quien sin titubear discrimina por edad cuando se imagina en la posición de un empleador que debe contratar a una secretaria.

Finalmente, un hallazgo destacable es la ausencia de críticas basadas en este marco en los grupos de las clases de servicios alta y de trabajadores independientes. Los resultados sugieren, entonces, que son las clases más bajas en la estructura social aquellas que perciben y critican más la desigualdad de trato en Chile.

\subsubsection{Igualdad de posiciones: "En el país somos tan importantes todos, tanto el que} está arriba como el que está abajo"

La crítica desplegada en los grupos de jugadores muestra un tercer marco de referencia, aunque mucho menos extendido y, en ocasiones, más bien implícito. Se trata de la igualdad de posiciones, entendida como un horizonte normativo donde la crítica apela a la necesidad de atenuar las diferencias en recursos que definen posiciones sociales, tales como el salario. El énfasis de este marco apunta, entonces, a que los lugares que ocupan las personas en distintos ámbitos sociales tiendan a la igualdad.

Dentro del grupo de la clase de servicios baja, Silvana, la administrativa en un cementerio, desarrolla una crítica sobre la dificultad que tienen quienes están en un nivel inferior en 
términos educacionales para llegar a las posiciones más altas: "Entonces la distancia de ellos a los universitarios es más lejana, e incluso, en una empresa, porque en una empresa ellos se contactan con los técnicos, no se contactan con los, con los profesionales, con el gerente". Andrea continúa el argumento de Silvana: "La jerarquía. Entonces ellos están más cercanos a los técnicos y los técnicos están más cercanos a los profesionales, como digo yo”. En esta última expresión existe una valoración negativa implícita de que las posiciones definidas por la educación, por ejemplo al interior de una empresa, marquen una distancia en la cotidianeidad. Por consiguiente, la crítica a la jerarquía pone de relieve el marco de la igualdad de posiciones, no obstante también se problematiza como una desigualdad en el trato. Se trataría de un juicio de realidad, en la medida que se sostiene en cierto grado el valor normativo de atenuar las distancias entre las posiciones sociales y se denuncia el que existan tales desigualdades.

Los jugadores del grupo de rutinas no manuales baja dan cuenta, a través de sus intercambios, de un marco de igualdad de posiciones. Discutiendo sobre una eventual división de los naipes según el aporte que hacen al país, Álvaro argumenta: "Pero yo creo que para que el país avance nos necesitamos todos, unos a otros, porque tal como dice él si no está el caballero que recibe basura, en una semana, cómo tengo el pasaje”. Fernando lo refrenda con un rápido “claro" y Álvaro continúa: "En el país somos tan importantes todos, tanto el que está arriba como el que está abajo, el que está arriba necesita del que está abajo para que le llegue lo que necesita arriba". Fernando lo complementa: "Es lo mismo que un médico que opera con bisturí. Y quien hace el bisturí, quien hace los utensilios. Porque hacer una pinza en metalúrgica, hay que también quemarse las pestañas”. Así, los jugadores dan cuenta de la importancia de reconocer en similar medida el aporte que cualquier trabajador hace a la sociedad, sin importar la ocupación específica, en tanto hay una codependencia de las tareas. De hecho, Bernardo reconoce la crítica -“es importante como argumento, que dices"- y Álvaro prosigue: "Y si seguimos dando vuelta, del millón de pesos que costó la operación, 800 lucas se llevó el doctor, 50 se llevó el otro, y al último, el caballero que vino a recoger la basura, cinco lucas". Mara también está de acuerdo: "Sí, es verdad”. De esta manera, queda en evidencia que existe cuestionamiento a la inequidad en la distribución de remuneraciones, considerando la necesidad de todas las labores involucradas. Por tanto, aparece como una crítica desde un marco de igualdad de posiciones. Resulta interesante que la interacción 
descrita expresa un proceso donde el resto de los participantes va elaborando la argumentación de Álvaro sobre el rol de distintas ocupaciones en la sociedad y manifiestan secuencialmente su acuerdo. En esta línea, aparece como un indicio de un proceso de reflexividad individual apuntalado por la narración del administrativo de Isapre.

Los trabajadores independientes, por su parte, exponen un marco de igualdad de posiciones cuando Loreto se refiere al grupo superior que construyeron: "Ellos van a estar siempre van a estar arriba, aunque no queramos, lamentablemente ellos siempre, va a influir...". Luego agrega el juicio expuesto en el inicio del apartado sobre lo poco probable de que quienes están más abajo en la estructura ocupacional lleguen al grupo superior. De tal manera, expresa un juicio de realidad basado en un principio normativo basado en que las posiciones sociales deben morigerar sus diferencias, en tanto critica la desigualdad de posiciones que, además, es percibida como irremontable. Además, se mezcla una crítica a las posiciones más privilegiadas, dentro del marco de igualdad de posiciones, con una enmarcada en la igualdad de oportunidades.

En definitiva, si bien son pocas las críticas expresadas desde un marco de referencia de igualdad de posiciones, estas son significativas en la medida que utilizan un conjunto de principios normativos que contrastan con los dos marcos ya revisados. Los juicios críticos de este marco sólo se encuentran en los grupos de la clase de trabajadores independientes, de servicios baja y de rutinas no manuales baja. La crítica enunciada en esta última clase por Álvaro es de particular interés, tanto por el desarrollo que se realiza de la misma, como por que sugiere haber activado un proceso de reflexividad en el resto de sus compañeros.

Como se ha visto, los marcos de referencia son una condición necesaria de la crítica social. Ahora bien, a pesar de que los marcos son parte constitutiva de esta crítica, ella no se limita a los criterios de evaluación de la realidad social que proveen estos marcos. La crítica social marca una distancia con una situación percibida, apuntando a distintos objetos. Comprender el aspecto al que atiende la crítica es el propósito del siguiente apartado.

\subsection{Los objetos de la crítica}

Los distintos objetos denunciados por la crítica pueden agruparse en tres dimensiones: la educación, el mundo del trabajo y la subjetividad. En algunas ocasiones, la crítica se dirige a objetos muy concretos, por ejemplo a que una empresa constructora no provea zapatos de 
seguridad a sus trabajadores; otras veces se denuncian cuestiones más abstractas o generales, como la impermeabilidad de la estructura social o la discriminación hacia las dueñas de casa. Además, en muchos casos el objeto de la crítica es el juicio mismo de un participante, lo que hemos denominado contra crítica. En el presente apartado revisamos cuáles son los objetos de la crítica -es decir, qué es lo criticado- según los grupos de jugadores de distintas clases sociales, tomando como base los ejemplos ya expuestos durante el capítulo.

La configuración de los juicios críticos analizados se esclarece a través de la distinción boltanskiana sobre los objetos de la crítica social (Boltanski, 2011). Por un lado, se encuentra aquella que toma como objeto la forma en que se desarrolla una prueba ${ }^{10}$ relativa a aspectos de juicios y legitimidad, evidenciando que no se respetaron los procedimientos establecidos socialmente. Así, las críticas que denuncian restricciones al ascenso social, pese a historias de esfuerzo son una ilustración de este tipo de objeto de la crítica. En la misma dirección, la crítica hacia una falta de oportunidades laborales y educacionales remite a la no constatación de lo esperado: una sociedad de oportunidades donde el mérito sea recompensado. Por otra parte, para el sociólogo francés se halla la crítica que se dirige hacia la prueba misma, situándose por fuera de su marco o principios de justicia. El caso de las denuncias sobre discriminaciones de estatus y salariales hacia ocupaciones más bajas o individuos menos educados responde a este tipo de crítica, en la medida que se oponen a las reglas sociales establecidas, por ejemplo, la producción de desigualdades legítimas a partir de los méritos individuales.

Los tipos de crítica según el objeto sea la forma en que funciona una prueba o la prueba misma dan lugar a las nociones de crítica reformista y radical, respectivamente. Como se revisó, la forma más generalizada de crítica es una de carácter reformista configurada a través de juicios de realidad que denuncian los problemas e injusticias de la realidad social, según cómo se espera que esta funcione. En esta dirección, se trata de una crítica tendiente a la reproducción social de la realidad. Todos los grupos focales dan cuenta de esta tendencia que

\footnotetext{
${ }^{10}$ La noción de prueba en Boltanski se refiere a la forma en que se evalúa la realidad social desde una perspectiva subjetiva, a partir de criterios correspondientes a ciertos marcos de la filosofía política que el autor ordena en seis categorías. A su vez, el sociólogo francés reconoce una filiación del concepto con la noción propuesta por Latour (1993).
} 
es reforzada por objetos de crítica relativos a las cortapisas que encuentran los principios que se espera orienten la realidad social, tales como la igualdad de oportunidades y de trato.

El juego de clasificaciones de la clase de servicios alta exhibe principalmente objetos de crítica vinculados con la segregación social en el ámbito laboral y educacional. Como ya se revisó, Gervasio, el ingeniero comercial, cuestiona las distancias producidas por la educación, que, junto a la comuna de residencia, la ocupación y otras características, marcan distinciones y barreras importantes entre las personas, según él. En esta línea, hacia el final del juego los participantes coinciden en la percepción de que existe una fuerte reproducción social de las desigualdades, producto de las restricciones laborales y educacionales. Según la crítica colectiva citada anteriormente, las personas que tienen ocupaciones manuales necesitan "como un millón de generaciones" para llegar a las altas, mientras que las posiciones intermedias tienen posibilidades de moverse sólo en un rango limitado y los que están ubicados más arriba seguirán beneficiándose de una desigual distribución de la riqueza. Los participantes de la clase social de servicios baja enfocan sus críticas en una dimensión subjetiva. Particularmente, es común que critiquen la falta de esfuerzo de quienes no logran surgir o, en positivo, que reconozcan a quienes "se sacan la mugre" para llegar a un mejor lugar en la estructura de ocupaciones. Así también, critican las restricciones para moverse entre posiciones laborales, matizando el componente subjetivo en el éxito personal. Otro objeto de denuncia del mundo laboral se observa en la crítica de Marcelo, quien considera, a partir de la carta que representa a un periodista, que existen ocupaciones mal remuneradas y dificultades para encontrar trabajo: "Yo tengo ejemplos cercanos de periodistas recién salidos, que les ha costado cualquier cantidad encontrar trabajo y el tema de la remuneración, también, es súper bajo". Por último, como muestra la discusión sobre los currículums que solicitan fotografía, la discriminación por edad y apariencia física también es objeto de la crítica de este grupo.

El grupo de rutinas no manuales alta apunta a objetos de crítica vinculados al ámbito laboral: bajos salarios, falta de oportunidades de empleo, discriminación etaria y condiciones precarias de trabajo. Por ejemplo, Lautaro critica la situación de los subcontratados: "Entonces lo que él gana, es lo que le estoy diciendo, es lo que realmente le paga la empresita estas de juguete que son contratistas, y ahí, y que se lleva a una persona superior por la plata”, 
lo que es secundado por Demeterio, quien generaliza la crítica señalando que esto sucede "en todos lados". La crítica desarrollada en esta interacción, entonces, denuncia lo injusto del subcontrato en términos de una discriminación en el mercado laboral que favorece a los dueños de las empresas contratistas. Por lo tanto, se trata de una crítica reformista que apunta a la corrección de una desviación del modelo según el que el mercado laboral debe remunerar acorde a las labores desempeñadas.

Por otra parte, este grupo de jugadores también critica la falta de esfuerzo personal. Si bien se reconocen problemas en el mundo del trabajo, como se desprende de las críticas realizadas, para algunos participantes buena parte de la responsabilidad de quienes no tienen éxito laboral es individual. Clara enfatiza que alguien "puede tener quinto básico y estar ganando seiscientos mil o un millón de pesos, es un tema de superación de cada uno", así como vimos que Demeterio defendía la creación de un grupo de "conformistas". Por su parte, Catalina contra argumentaba que los sueldos en general en Chile eran bajos, y que no se trata de un problema de conformismo. De esta manera, critica el nivel de las remuneraciones. Más adelante, Martín destaca una carta que representaba a un ingeniero mapuche en el grupo de los ganadores. Subraya el alto sueldo del personaje, pese a que "hoy en día se discriminan bastante [a los mapuches]". Clara agrega: "Sí, y él podría decir que lo discriminan por ser mapuche $[\ldots]$ Pero si él se quedara con la discriminación se quedaría echado ahí po". A su vez, Martín ilustra sintéticamente el objeto de la crítica: "Es una cosa de superación". Por lo demás, están las críticas enunciadas a partir de la percepción de mayores facilidades para acceder a la educación en distintos niveles, en comparación al pasado, que contribuyen a denunciar la responsabilidad individual de quienes están en posiciones no privilegiadas y no ascienden socialmente. De tal forma, estos objetos constituyen una crítica de carácter reformista al remitirse a un correcto funcionamiento de la realidad social según principios meritocráticos.

Para los jugadores de rutinas no manuales baja, el principal objeto de la crítica se refiere a las discriminaciones educacionales. Especialmente, se denuncia el privilegio de quienes tienen títulos profesionales, pese a que en muchos casos son los técnicos los que hacen la mayor parte del trabajo, como se ve en una crítica de Bernardo citada anteriormente. En este sentido, Mara comenta: "Si no ha tenido una profesión, no vale nada acá en Chile, no eres 
nada". Más adelante, Álvaro describe a quienes no han podido terminar su enseñanza media como "las personas que quedaron a medio camino", enfatizando la "completitud" personal que puede proveer la educación. La dimensión educacional también aparece como objeto de crítica al recordar la discusión que tiene el grupo sobre la necesidad de todas las ocupaciones, más allá de los niveles de especialización y educación que requieran. Siguiendo con el ejemplo del médico que necesita al fabricante del bisturí, al enfermero, y a la persona que limpia el pabellón, Álvaro problematiza:

¿Quién se lleva los aplausos en una operación? El doctor. ¿El doctor dónde pasó? Terminó la universidad. Y el que estaba al lado de él, el que le estaba pasando los materiales es técnico, y el que le puso la anestesia, porque el anestesista también es importante, porque si el anestesista se pasa un poquito, lo mata, el paciente despierta en la operación. Entonces todos dependen, y la persona que hizo el aseo en la sala de operaciones.

Aquí se reenfoca un objeto similar de crítica, antes de carácter reformista, hacia una de tipo radical, en tanto se basa en principios de igualdad de posiciones que contrastan con los de la realidad social que reconocen los participantes durante la interacción. El cuestionamiento colectivo que gatilla Álvaro apunta a lo que Boltanski denomina denunciar la prueba misma $\mathrm{y}$, entonces, a los principios de justicia que cimientan la realidad social. Cuestionar la prueba meritocrática es, en este caso, reconfigurar la crítica en términos radicales.

También aparecen críticas a la mala calidad de la educación. Fernando comenta sobre la formación técnica: "Lo que pasa es que hay muchas escuelas técnicas, liceos técnicos que salen como contador general, técnico en aire acondicionado, y todo eso y lamentablemente salen de mala forma”. A su vez, se conecta con una crítica a los sostenedores de colegios particulares subvencionados que, según Fernando, no tienen un buen desempeño: "Y lamentablemente tienen que cambiarse [los estudiantes técnicos] cuando no les dan los conocimientos, porque no hay una política de fiscalización, o la gente que está digamos sosteniendo a esos colegios, que sea gente idónea, afín”. Continúa criticando con vehemencia el sistema de educación técnico a través de un ejemplo que considera de especial gravedad, pues considera que tiene relevancia para la producción en general: "hay malos profesores, los sostenedores son ladrones hasta decir basta, porque yo estudié en eso, y de repente 
llegaban los ladrillos, tuberías, y el director se llevaba todo, y derribaba esa muralla, y saca los mismo escombros y hácete otra muralla".

En el mismo grupo, aparecen críticas a aspectos del mundo laboral: bajos salarios, condiciones precarias, uso de influencias o pitutos y, vinculado con las críticas a la educación, una denuncia del desprecio que perciben hacia los trabajadores no profesionales. Sobre este último objeto de crítica, mientras discuten acerca de cuál naipe seleccionar como representante de un grupo, Álvaro hace una acotación respecto a la cantidad de oportunidades con que cuentan los personajes representados en ellos: "Y eso lamentablemente es así, la persona que tiene estudios, lamentablemente tiene más oportunidades”. Asimismo, Mara comenta cómo era cuestionada por su ocupación, al tener que criar tres hijos: "Y todos me decían, 'pero si eres garzona nomás, garzona', sí, pero garzona y crie tres hijos”. En este caso, contrasta el principio de igualdad de oportunidades con el de meritocracia educacional. Si bien el objeto de la denuncia constituye una crítica reformista relativa a las oportunidades disminuidas para quienes alcanzan menos educación formal, lo hace al costo de poner en suspenso la forma legítima para la realidad social de producir desigualdades a través de la educación.

Por último, en el juego de la clase de rutinas no manuales baja, se toma como objeto de la crítica aspectos más subjetivos, específicamente la falta de esfuerzo y el conformismo de la clase media. Se critica la falta de iniciativa para pasar a ser independientes, es decir, dejar de ser "apatronados". Fernando, el técnico en instalaciones sanitarias, comenta en un intercambio: "Lo que pasa es que dentro de la clase media también están metidos, cuesta dar el paso porque también cuida la pega. Te están pagando una cantidad un poquito mayor que al resto de los inocentes, al final están sometidos". Esta crítica dirigida a una dimensión subjetiva, según considera que los individuos privilegian la seguridad material frente al riesgo asociado a escapar al sometimiento del asalariado, tiene implicancias para la crítica. Se trata de una crítica que pone al descubierto la preferencia cotidiana por la reproducción del statu quo. Ahora bien, no obstante la denuncia se dirige a la reproducción de una situación considerada como injusta, también la misma crítica tiende a reproducir la realidad social, al cuestionar esta tolerancia de la injusticia desde la responsabilidad individual. Esto ya que se critica el ser asalariado como un rezago basado en falencias o incapacidades individuales - 
el conformismo y la falta de esfuerzo-. De tal forma, aunque se critique la tendencia a la reproducción de la desigualdad producida por la asalarización, la crítica se erige desde los principios de justicia anclados en la realidad social.

Los jugadores que pertenecen a la clase de trabajadores independientes elaboran críticas sobre todo hacia objetos del mundo laboral. Destacan las desigualdades salariales, ya sea entre personas con similares niveles de educación y distintas remuneraciones, o entre posiciones distintas. Respecto a este último caso, Isabel comenta poco antes del fin de la interacción, a modo de cierre: "Que se aprovechan nomás los de arriba [de] los de abajo, porque ahí se ve la diferencia de lo que ellos ganan y quién le paga a ellos mucho, los de arriba", refiriéndose con esto último a una élite que beneficia a los profesionales. José aprueba la crítica dicha: "Y así va a ser". Anteriormente, al analizar un naipe con una remuneración muy baja, la interpretación de Isabel fue que "ese es un aprovechamiento de los que tienen mucha plata". Durante ese intercambio los jugadores dialogan sobre las pensiones existentes consideradas como insuficientes, haciendo de estas su objeto de crítica. También se denuncia la inestabilidad laboral. Loreto apunta sobre un par de naipes que representan profesionales: "le pusieron profesionales, pero son inestables, por la condición que tienen". Isabel agrega: "Como son, porque se les paga mucho, resulta que después preparan a una persona, le enseñan lo mismo de arriba, y contratan tres cuatro personas por lo mismo". El punto es refrendado por José, mostrando su acuerdo con la crítica -“Correcto, como lo están haciendo en muchas partes"-.

Un último objeto de crítica en la dimensión laboral se refiere a las diferencias más estructurales que marcan la persistencia y reproducción de las desigualdades en este ámbito. Loreto dice sobre quienes se desempeñan en las ocupaciones superiores: "Ellos nacieron así, que eso es lo otro. Que nosotros decimos que ese tipo de gente, nace en cuna de oro, entonces...”. Este punto es reafirmado por Raúl -“nace en una buena vida”- y por José -“Les da lo mismo"-. En la misma línea, ya se vio la crítica a lo improbable de ciertas movilidades en la estructura social. De tal forma, la crítica que emerge en la interacción de los trabajadores independientes apunta a la producción ilegítima de desigualdades sociales, que no se basan en los criterios esperados para el éxito laboral o educacional, como son los privilegios heredados. 
Otro objeto de crítica de este grupo de participantes se enfoca en un ámbito más subjetivo. De forma parecida a como otros grupos de jugadores lo hicieron, estos trabajadores independientes apuntan críticamente al conformismo de algunas personas. Junto con las restricciones a la movilidad de carácter más bien estructural, también consideran que opera un factor individual, relativo a la falta de esfuerzo y voluntad para salir adelante, que explica una posición desaventajada. Así, Isabel considera que un movimiento ascendente desde las ocupaciones más bajas hacia un mejor empleo contempla un importante factor subjetivo: "Tienen que ser gente que quiera superarse mucho, para estudiar y sacrificarse". Todavía más ilustrativa es la conversación entre Loreto e Isabel sobre un naipe que representa a un profesor con bajo sueldo. La última dice "poco esfuerzo lo encontramos” mientras la otra agrega: "Le pusimos que él es una persona que está resignada, que tiene que asumir el tipo de sueldo como mediocre". Las mismas jugadoras son las que criticaban la posición de dueña de casa, en tanto "no se esfuerzan nada". Nuevamente, la crítica se torna reformista al denunciar faltas a la forma legítima de producir desigualdades, es decir, el esfuerzo individual.

El ámbito laboral también es el principal objeto de crítica para los trabajadores manuales. Como fue revisado, desde el marco de referencia de igualdad de trato, estos jugadores cuestionaban la discriminación hacia ocupaciones inferiores de quienes están en mejores posiciones, destacando las distancias que perciben entre jefes y empleados. Hernando conceptualiza esta desigualdad laboral como clasismo, según expresa que "hay, hay gente que son muy digamos dura, clasista, que no se pueden [...] No quiere porque no quiere, su, por su ego, no quiere relacionarse con la otra". Otro foco de denuncia en este ámbito es el uso de influencias y "pitutos" para encontrar trabajo, del que se privilegian quienes tienen mejores posiciones, lo que a su vez lleva a una crítica a la reproducción social. Al hablar sobre un naipe, Pamela lo ilustra de la siguiente manera: "se puede decir que su papá era amigo del gerente y por ahí hicieron el pituto, típico que se da aquí, entonces ella ya tiene su, su vida segura”. Cabe destacar que esta narración proviene de la jugadora, no aparecía en ninguna parte del juego.

Asimismo, los participantes también critican el desprecio y la sospecha que muchas veces tienen los superiores respecto a sus subalternos. Por ejemplo, Nadia se refiere a la humillación que sintió una vez que fue objeto de sospecha por robo en su lugar de trabajo. 
Pedro reconocía este hecho como un fenómeno más general, en tanto ocurría en barrios de ricos donde había una discriminación hacia empleadas domésticas y trabajadores de la construcción. Por lo tanto, se expresa una fuerte crítica al maltrato que sufren quienes, como los mismos jugadores, se encuentran en posiciones ocupacionales desaventajadas.

Los jugadores de esta clase social también comparten la crítica a la falta de esfuerzo. Desde su punto de vista, la resignación, el conformismo y la falta de esfuerzo explican parcialmente la ocupación de posiciones bajas de algunas personas. Por esto, en sentido positivo, se observa que los participantes ven el esfuerzo y la tenacidad personal como una vía para evitar el maltrato y las consecuencias de la desigualdad a los que se ven expuestos, principalmente a través de la educación. La crítica de los trabajadores manuales se configura, de forma similar a la de otros grupos revisados, como una denuncia de lo injusto de que ciertos actores y grupos sociales pasen por encima de la legítima manera de producir desigualdades a través del mérito individual. La crítica a distintos objetos se torna reformista al concentrarse en lo inadecuado de las posiciones sociales que, por ejemplo, usufructúan de sus linajes familiares para obtener ventajas comparativas durante su trayectoria de vida. Se trata, en términos de Boltanski, de una crítica a la desviación de una prueba que, para los participantes, debe ser enmendada en pos de la justicia.

Adicionalmente, en el ámbito subjetivo surge una crítica hacia las expectativas y las relaciones interpersonales de quienes tienen las mejores situaciones. Nadia contrasta la forma de vida de un nosotros con un ellos:

Que nosotros vivimos pendiente de todo; de la familia y de nosotros. Somos como bien unidos, todo comemos, Navidad, Año Nuevo, todos unidos, o sea, cumpleaños, todos unidos, entonces somos como unidos, pero ellos no, porque ellos tienen escalar, que seguir escalando, seguir creciendo.

Juan aprueba este argumento, agregando: "Tienen que mantenerse en el estrato en que ellos están", y Nadia continúa: "Porque si te bajas, estás frito".

Como último objeto de crítica de los trabajadores manuales, cabe relevar la discriminación racial como objeto de crítica, a propósito de la anécdota de Pedro sobre el insulto - “Córrete, indio!"- que recibe en un lugar asociado con gente rica. Se trata de una crítica que denuncia 
la discriminación racial y que sitúa a este tipo de discriminación como un objeto relevante de crítica. En general, se critican distintas discriminaciones, como las por género o clase. En menor medida, aparece en la crítica la denuncia de la discriminación racial, siendo esta y la del grupo de rutinas no manuales baja las únicas dos oportunidades en los seis grupos donde se exhibe.

A modo de síntesis de los objetos de la crítica social, en la tabla 6.1 se presentan cuáles son y las dimensiones a las que corresponden.

Tabla 6.1. Dimensiones y objetos de la crítica social en los seis grupos focales

\begin{tabular}{|c|c|c|}
\hline Clase social & $\begin{array}{l}\text { Dimensión del } \\
\text { objeto de crítica }\end{array}$ & Objetos de crítica \\
\hline \multirow{2}{*}{ I. Servicios alta } & Laboral & $\begin{array}{l}\text { Reproducción intergeneracional de la } \\
\text { desigualdad por restricciones laborales }\end{array}$ \\
\hline & Educacional & $\begin{array}{l}\text { Reproducción intergeneracional de la } \\
\text { desigualdad por restricciones educacionales }\end{array}$ \\
\hline \multirow[t]{2}{*}{ II. Servicios baja } & Laboral & $\begin{array}{l}\text { Discriminación por edad y apariencia física, } \\
\text { restricciones al ascenso en puestos de trabajo }\end{array}$ \\
\hline & Subjetiva & Falta de esfuerzo individual para superarse \\
\hline \multirow{2}{*}{$\begin{array}{l}\text { IIIa. Rutinas no } \\
\text { manuales alta }\end{array}$} & Laboral & $\begin{array}{l}\text { Bajos salarios, falta de oportunidades de } \\
\text { empleo, discriminación por edad en el trabajo, } \\
\text { condiciones de trabajo precarias }\end{array}$ \\
\hline & Subjetiva & $\begin{array}{l}\text { Falta de esfuerzo individual para superarse; } \\
\text { discriminación hacia mapuches }\end{array}$ \\
\hline \multirow{2}{*}{$\begin{array}{l}\text { IIIb. Rutinas no } \\
\text { manuales baja }\end{array}$} & Laboral & $\begin{array}{l}\text { Privilegio injusto de quienes poseen títulos } \\
\text { profesionales; bajos salarios; condiciones de } \\
\text { trabajo precarias; uso de influencia y pituto }\end{array}$ \\
\hline & Educacional & $\begin{array}{l}\text { Discriminación en ámbito educacional a } \\
\text { formación no profesional, mala calidad de la } \\
\text { educación técnica y particular subvencionada }\end{array}$ \\
\hline \multirow[t]{2}{*}{$\begin{array}{l}\text { IVb. Trabajadores } \\
\text { independientes }\end{array}$} & Laboral & $\begin{array}{l}\text { Desigualdades salariales; connivencia entre } \\
\text { élite y profesionales; persistencia y } \\
\text { reproducción de las desigualdades en el trabajo; } \\
\text { pensiones insuficientes }\end{array}$ \\
\hline & Subjetiva & Falta de esfuerzo para salir adelante \\
\hline \multirow{2}{*}{$\begin{array}{l}\text { VI. Trabajadores } \\
\text { manuales }\end{array}$} & Laboral & $\begin{array}{l}\text { Discriminación en el trato a quienes ocupan } \\
\text { posiciones bajas; distancias entre jefes y } \\
\text { subordinados }\end{array}$ \\
\hline & Subjetiva & $\begin{array}{l}\text { Clasismo; discriminación en el trato a quienes } \\
\text { ocupan posiciones sociales bajas; } \\
\text { discriminación hacia indígenas }\end{array}$ \\
\hline
\end{tabular}

Fuente: Elaboración propia 
Las dimensiones de crítica -laboral, educacional y subjetiva- encontradas en los grupos focales son consistentes con los hallazgos de otros estudios contemporáneos. La dimensión laboral de la crítica social se vincula con las injusticias reportadas en términos de la brecha salarial justa (J. C. Castillo, 2012b) y otros hallazgos sobre injusticias distributivas. La crítica en una dimensión educacional tiene un correlato con el proceso del movimiento social por la educación en Chile que se expresa con particular fuerza el año 2011, criticando distintos aspectos del sistema educacional del país (Bellei, Cabalin, \& Orellana, 2014). Por último, las críticas, malestares y denuncias de injusticia desde una dimensión subjetiva han sido resaltadas en la investigación de Araujo y Martucelli (2011, 2012), entre otros.

La consistencia de los objetos de denuncia encontrados en este análisis con los de otros estudios sugiere la existencia de tópicos de atención generalizados y compartidos en la población de Chile que provienen de una labor de institucionalización de la crítica. Desde una perspectiva pragmática, entonces, los resultados apuntan a críticas compartidas y altamente contextualizadas que emergen en la interacción. Tales críticas se nutren de aspectos percibidos por individuos comunes como centrales para el orden social -el trabajo, la educación y el trato-, cuestión que genera matices y focalizaciones distintas según clases sociales. De forma complementaria, existen expectativas relativas a cómo deben funcionar estos aspectos centrales de la realidad social, lo que configura en principios de justicia con los que se evalúa.

Finalmente, las distinciones que se producen en los objetos de la crítica según clases sociales se asocian a la posición de estas en la estructura social. De tal forma, los trabajadores manuales denuncian el clasismo y la desigualdad en el trato, especialmente a partir de experiencias de discriminación de clase y maltrato vividas por ellos o cercanos. Por otra parte, los jugadores de la clase de rutinas no manuales baja critican la discriminación hacia los técnicos en favor de los profesionales. La clase de servicios alta, en cambio, orienta sus juicios críticos hacia aquellos que reproducen sus posiciones sociales a través de cierres sociales como el pituto o la educación de élite. 


\subsection{Tipos de crítica y reflexividad}

El ejercicio de clasificar colectivamente los perfiles de personas pone de manifiesto los horizontes normativos, los objetos de la crítica y, por supuesto, las formas específicas en que se critica. Durante la interacción provocada por el juego salen a la luz críticas a distintos aspectos de la realidad social que, en algunos casos, generan disputas, discusiones, acuerdos o desencuentros entre los jugadores. La división de la crítica en marcos de referencia, objetos y formas de realización es analítica, pues esta tiene lugar como un fenómeno integral, que tiene lugar a nivel interaccional. Considerando esto, en la presente sección analizamos el carácter general de la crítica, enfatizando los aspectos de interés anunciados en acápites anteriores: se retoma una tipología de la crítica y luego se analizan las implicancias de esta para los procesos de cambio y reproducción social. En atención a la hipótesis que guía esta investigación, también es de interés observar el lugar de la reflexividad en los juicios críticos.

Por una parte, vimos que la crítica social se realiza a través de interacciones comunicativas que despiertan una mayor atención entre los participantes. Aquello constituye una condición necesaria para la reflexividad, siguiendo la consideración de Boltanski acerca de los momentos de alta reflexividad como aquellos donde la atención se vuelca hacia la pregunta por cómo se debe caracterizar o cualificar una situación dada. Consecuentemente, los momentos metapragmáticos, es decir, en los que se eleva el nivel de reflexividad, hacen posible el curso de la crítica social. Se trata precisamente de momentos como aquel cuando un técnico en armado de computadores, Demeterio, planteaba la pregunta: "Pero nosotros, ¿actuamos todos iguales?”. Por otra parte, dentro de los aspectos formales, la contra crítica es interesante en relación a la reflexividad: manifiesta la presencia efectiva de procesos comprensivos y argumentativos, basados en marcos normativos diferentes. Si bien en algunos casos sólo se llega al silencio o la risa al enfrentar juicios y contra juicios críticos, en ciertas ocasiones los jugadores terminan compartiendo posiciones o concediendo puntos

de la crítica del otro. Tal como Álvaro termina compartiendo la posición de Fernando sobre la virtud de trabajar como independiente en el juego de rutinas no manuales baja. Contra una visión fatalista que desestima la posibilidad del entendimiento y empatía a través del intercambio de críticas, los resultados sugieren la presencia de procesos apuntalados por la reflexividad capaces de desplazar las posiciones originales y llegar a acuerdos. 
Los principales marcos de referencia identificados dan cuenta de conjuntos de principios muy distintos y, en algunos casos, opuestos. Grosso modo, la defensa de la postura de igualdad de oportunidades es incompatible con la de igualdad de posiciones, en tanto se contrapone el abogar por condiciones de desarrollo iniciales similares para todos, que pueden dar lugar a legítimas diferencias, o por una equivalencia en los réditos que otorgan distintas posiciones sociales (Dubet, 2013). Sin embargo, pueden convivir críticas animadas por ambos marcos en las mismas personas, en tanto no tienen necesariamente un constructo sistemático y del todo coherente para evaluar la realidad social. Por su parte, el marco de referencia de igualdad de trato puede actuar como un complemento o una diferencia de énfasis significativa. Así, como se observó en la clase de los trabajadores manuales, en comparación a las clases medias, donde priman las críticas basadas en el maltrato o la necesidad de una igualdad de trato. Paralelamente, en el grupo de trabajadores manuales se enuncian críticas desde la igualdad de oportunidades. En consecuencia, los marcos de referencia coexisten en los distintos grupos de clases sociales, con énfasis distintos puestos en cada uno.

Tomando en cuenta el panorama en general, una crítica compartida por todos -a excepción de la clase de servicios alta-, se dirige hacia el conformismo, la falta de esfuerzo y/o la resignación de quienes se encuentran en posiciones desaventajadas. Esta forma de justificación constituye una importante manera de legitimar la realidad social en su estado actual, a través del atomizar la responsabilidad en casos aislados. Por lo tanto, esta crítica compartida tiende a la reproducción del statu quo. Sin embargo, esta crítica convive con la denuncia de mecanismos sociales de carácter más estructural que impiden el ascenso o mejores condiciones de vida. De todas formas, esta última crítica no tiende a formularse junto a imperativos de cambio o propuestas de transformación. Aquello contrasta con otras críticas, como por ejemplo cuando se apunta a la discriminación etaria, de género o étnico-racial, donde sí se considera que debiera realizarse un cambio. Las críticas a aspectos estructurales aparecen mayormente como situaciones que deben ser corregidas más que transformadas en algo nuevo o sustancialmente distinto. Considerando esto, junto a la primacía del marco de igualdad de oportunidades, se deduce que la principal forma de crítica en los juegos de clasificaciones se circunscribe a los límites normativos de la realidad social actual, por lo que, en la nomenclatura de Boltanski, se trata de una crítica de carácter reformista, en tanto se apela a que se cumplan las promesas que el contexto actual presenta. En este caso, esto 
significa que efectivamente opere una meritocracia donde todos tengan posibilidades similares de desarrollarse a través del esfuerzo personal, tratándose con un respeto adecuado sin importar la posición social de cada uno.

La (re)producción de normas también constituye un punto relevante para la crítica. La anécdota narrada por Nadia, la auxiliar de aseo, sobre la humillación que sintió en su lugar de trabajo -y el énfasis que la jugadora hace en cómo se preocupó de transmitirle esta experiencia a sus hijos- es ilustrativa de los mecanismos de surgimiento y reproducción intergeneracional de los marcos de referencia y la crítica social. Acciones de este tipo, donde se problematiza la posición de sí en la sociedad y se enuncia a cercanos, son subsidiarias de procesos reflexivos; en este caso uno motivado por la preocupación maternal de conseguir un mejor futuro para sus hijos. Asimismo, en el grupo de la clase de rutinas no manuales baja el contraste producido por la rápida reacción de Fernando frente al juego que le propone Álvaro, donde elige como secretaria en una situación hipotética a la mujer más joven, frente a su discurso contra la discriminación de las mujeres, da cuenta de diferentes niveles de reflexividad. La celeridad y espontaneidad con que responde a Álvaro en la primera situación indica una baja reflexividad, en contraste con la respuesta donde denuncia el "machismo" y la postergación de las dueñas de casa con una intervención más extensa y elaborada.

Como se ha visto, algunas críticas se alejan de la igualdad de oportunidades y de trato, aunque también se enfocan en la educación y el trabajo. Pese a su escasez y aislamiento, incluso dentro del discurso de los mismos jugadores, la crítica desde la igualdad de posiciones es un fenómeno interesante de apuntar. Un buen ejemplo lo constituye la discusión que se produce en el grupo de rutinas no manuales cuando valiéndose de procesos reflexivos se imaginan la situación hipotética de que nadie recoja la basura de la calle o cuando atribuyen una importancia similar a las distintas ocupaciones que intervienen en una operación quirúrgica, a pesar de los disímiles niveles de educación que requieren. Este debate sienta las bases de una crítica diferente: en primer lugar, el registro metapragmático toma preeminencia, aquel que supone un mayor nivel de reflexividad, ya que los participantes se cuestionan cómo se constituyen ciertos procesos; particularmente sobre la provisión de servicios en los ejemplos presentados. No sólo consideran las cosas tal cual son en la realidad, sino que abordan otras realidades posibles que no se corresponden con lo existente. Al preguntarse por el valor 
relativo de distintas ocupaciones, dan cuenta de un hecho: las diferencias, como las de nivel educacional, producen una desigualdad injusta. Así, cuestionan la legitimidad de tal distribución desigual; en este caso, evidenciando la necesidad de todas las ocupaciones, incluso de las consideradas más bajas, como recoger la basura. En suma, un proceso de crítica como esta da pie a lo que Boltanski llama crítica radical.

Cabe destacar, entonces, que la crítica radical muestra un nivel mayor de reflexividad, según la recurrente serie de preguntas que la nutre y la distancia que se produce con la realidad tal cual se presenta. Ahora bien, no se desprende de esto que las otras críticas desarrolladas no puedan tener un alto nivel de reflexividad. Aun así, un hallazgo relevante es que efectivamente se encuentra una asociación general entre la reflexividad y la crítica social. Los resultados sugieren que existe un mayor nivel de reflexividad en las críticas de carácter radical. Esto último es un elemento que requiere profundización, en parte por la baja presencia de críticas de carácter radical y por el diseño del estudio que se limita a un grupo focal por cada clase social. 


\section{Conclusiones}

Denunciar lo injusto es un proceso complejo y abierto al amplio abanico de principios normativos que pueden ser utilizados para definir una situación como (in)justa. No obstante, en los seis grupos analizados - correspondientes a clases medias de la sociedad chilena, además de un grupo de trabajadores manuales- se encuentran ciertos patrones generales, así como particulares a cada clase social. Tanto en los marcos de referencia de la crítica social, como en las formas en que se canaliza y los objetos a los que se dirige, se hallan regularidades que permiten ahondar en el carácter de la crítica en Chile actual.

Primero, el contexto de interacción observado en los grupos focales evidencia formas específicas en que se despliegan los juicios críticos. Junto a la enunciación de frases, se observa una asociación de los juicios críticos a miradas atentas, mayor concentración que en el resto de la comunicación y mayores movimientos del cuerpo de quien la enuncia, especialmente de las manos y los brazos. La realización de juicios críticos también da lugar a una forma específica de juicio crítico que hemos denominado contra crítica. Básicamente, esta consiste en una crítica a modo de réplica a una anterior. Este tipo de interacción refuerza el hallazgo de una mayor atención a los juicios críticos y da cuenta del carácter provocador que tiene la crítica. La reacción de contra crítica se vincula también con un momento de mayor reflexividad, en tanto requiere un nivel de elaboración mayor que otros momentos comunes de la interacción comunicativa.

En segundo lugar, los principios de justicia utilizados se pueden agrupar en tres grandes marcos de referencia en los que cristalizan los juicios críticos enunciados en contextos de interacción: la igualdad de oportunidades, de trato y de posiciones. Proporcionalmente, prevalecen las críticas fundadas en un marco de igualdad de oportunidades. La idea de recibir recursos según el esfuerzo personal, asumiendo oportunidades equivalentes, resuena con fuerza entre los participantes. El marco de referencia de la igualdad de trato es bastante frecuente, especialmente en la clase de trabajadores manuales, y se basa en principios relativos a las normas de un trato digno, respetuoso e igualitario entre individuos, sin miras a su posición social. Por último, el marco de igualdad de posiciones es más bien excepcional, pero muy interesante al dar luces sobre momentos de mayor reflexividad y configurar una crítica cualitativamente distinta, de carácter radical. 
Los juicios críticos toman dos formas en la tipología de Boltanski: reformista y radical. La primera se caracteriza por cuestionar una desviación de cierto marco normativo fundado en el discurso dominante en el contexto existente. Se trata, por tanto, de un criterio según el que los individuos evalúan -y critican- aspectos de la realidad a partir de lo que perciben que existe en esta misma: lo que se percibe es un referente fundamental para lo que justifica. En otras palabras, una crítica reformista tiene lugar cuando alguien evalúa los ingresos de un trabajador tomando como su referente principal lo que percibe son los ingresos de trabajadores homólogos en ese contexto, por ejemplo, atendiendo al nivel educacional y la experiencia laboral. La lógica de la crítica reformista apunta, así, a que se corrijan las desviaciones de los marcos normativos existentes: si en el contexto el esfuerzo es premiado, se critica a quienes poseen gratificaciones sin esforzarse. Por lo mismo, predominan los juicios de realidad basados en un criterio contextual o realista, donde operan principios normativos según los que "las cosas funcionan de esa forma" en tanto "así es la realidad" como apunta un participante-, sin cuestionar el origen de tales normas. En definitiva, para la crítica reformista se trata de un problema de reglas establecidas que no funcionan igual para todos. En ese sentido, si bien se acepta que la desigualdad se produzca a través de algunos mecanismos, como el esfuerzo individual y los méritos en la educación, se denuncia lo injusto de cómo algunos grupos y actores excepcional o sistemáticamente pasan por encima de tales normativas. La prevalencia de las críticas de tipo reformista sugieren una fuerte tendencia de los juicios críticos con procesos morfostáticos que apuntan a reproducir las estructuras sociales dominantes.

En cambio, la crítica radical cuestiona utilizando principios que exceden a aquellos fundados en la realidad -en el sentido de lo socialmente construido--, sino que se dirige a denunciar la lógica misma de esos principios normativos predominantes. En estos casos, se cuestiona la regla establecida y no si lo que ocurre en la realidad se ajusta a estas. De tal manera, mientras algunos participantes de los grupos focales critican el maltrato recibido por tener una posición social desaventajada cuando las normas del contexto apuntan a que, independientemente de la posición que se ocupe, todos merecen un trato respetuoso, otros van a criticar la desigualdad presente entre las posiciones sociales mismas. Así, se opone una crítica reformista a otra radical. En este caso, los resultados sugieren una asociación entre la crítica radical y los procesos de morfogénesis vinculados con el cambio social. La mayor 
reflexividad asociada al marco de igualdad de posiciones deriva en parte de que la crítica fundada en este marco supone principios de justicia lejanos a lo que existe en la realidad social.

Los juicios críticos observados además dan cuenta de objetos de denuncia relativos a tres áreas principales: laboral, educacional y subjetiva. En términos generales, se denuncian cuestiones como los bajos salarios, la falta de oportunidades, la discriminación educacional y racial, así como la falta de esfuerzo individual. La clase de servicios alta, por ejemplo, se enfoca en la reproducción intergeneracional de la desigualdad producida en los estratos más altos a través de cortapisas en el mundo educacional y laboral. Ningún juicio crítico de este grupo apunta al maltrato cotidiano, lo que contrasta con los trabajadores manuales, quienes resaltan entre sus críticas especialmente el maltrato vivido en las interacciones cotidianas. Así también, la clase de rutinas no manuales baja critica lo que considera una sobrevaloración de los títulos profesionales en detrimento de los técnicos, como los que ellos poseen. De tal manera, se observa una asociación entre los objetos de la crítica y las situaciones que más afectan a las posiciones de clase. Esto reafirma la relación entre la crítica y el contexto, en este caso la posición social ocupada, reforzando el vínculo entre crítica reformista y procesos de morfostasis social.

En definitiva, se observa que existe un criterio realista o contextual de la crítica asociado a la legitimación de desigualdades sociales. Las reglas que se consideran legítimas, como la asignación de recursos por el esfuerzo en educarse y al trabajar, emanan de lo que se percibe operando en la realidad. La mayoría de los juicios críticos están formulados en términos de corregir las desviaciones de estas normas. Esto entronca con hallazgos de otros estudios recientes en los que se ha destacado el rol del enfoque existencial (lo que es) sobre los principios normativos de los individuos (J. C. Castillo, 2011). Aun así, se presentan algunas excepciones, como el marco de igualdad de posiciones, donde se cuestionan diferencias fuertemente arraigadas entre profesionales de prestigio, como los médicos, frente a ocupaciones de menor estatus como auxiliares de aseo y basureros.

La crítica social analizada muestra, al menos parcialmente, cómo operan procesos genéricos de reproducción de la desigualdad en Chile. A partir del contexto de interacción de los grupos focales se puede observar la forma en que se producen discursos de justificación y 
reproducción de la desigualdad, en consonancia con los procesos genéricos propuestos por Schwalbe y colegas (2000). Los juicios críticos presentan elementos asociados a los cuatro mecanismos identificados por los autores. En primer lugar, aparece una alterización (othering) donde se crean categorías para clasificar ciertos estereotipos, como ocurre con la denominación de los conformistas, quienes no se esforzarían para tener éxito en la vida según buena parte de los participantes. Vinculado con este ejemplo, también se observan mecanismos de administración de emociones (emotions management). Al encasillar discursivamente a ciertos estereotipos como conformistas, los participantes implican la presencia de una norma que requiere una proactividad y actitud de emprendimiento constantes, asociada a una serie de expectativas emocionales de supresión de goce e inconformismo. También el mantenimiento de fronteras (boundary maintenance) aparece recurrentemente en los juicios críticos, especialmente cuando se habla de cómo ciertos grupos excluyen o discriminan a otros, por ejemplo, los profesionales a los técnicos. Por último, la adaptación subordinada (subordinate adaptation) se refleja en la aceptación generalizada a las formas de dominación que existen, por ejemplo, en las jerarquías laborales, mientras se puedan satisfacer necesidades vitales.

La crítica social puede ser una contribución a la reproducción de las desigualdades sociales, principalmente porque los horizontes normativos que utiliza son contextuales. En este caso, el contexto chileno en que se sitúa la crítica es altamente desigual en distintos ámbitos y los individuos de las clases medias recurren principalmente a marcos de referencia y principios normativos coherentes con él. Las críticas que denuncian injusticias más allá de las normas contextuales se encuentran asociadas a señales de mayor reflexividad en la interacción de los grupos focales. Los resultados, así, sugieren que el ejercicio de una crítica reflexiva, es decir más elaborada y atenta, se vincula con disposiciones a normas sociales más disruptivas y, en este caso, vinculadas con la igualdad de posiciones.

Las tradiciones de la teoría crítica, en sentido amplio, han puesto un acento en el rol de la crítica como herramienta de reflexión y transformación de la sociedad. Así, el llamado de Marx (1982) a tornar hacia la crítica de la tierra -bien podría decirse la crítica de la realidad social- busca provocar un paso considerado como necesario para cambiar estructuras fundamentales de la sociedad que aparecen como injustas. Poco puede lograrse, desde esta 
visión, si la crítica se mantiene a nivel de las puras ideas. Una crítica transformadora toma como objetos cuestiones sociales acuciantes, las elabora teóricamente y proyecta intervenciones en la praxis para producir un nuevo orden social. Los resultados aquí presentados cuestionan la eficacia de la crítica en la trasformación del orden social, al menos para el caso de individuos no expertos de clases medias. Si bien la crítica ordinaria expuesta es tributaria de las experiencias observadas en la realidad, tiende a restringirse a los marcos normativos que esta misma le impone, es decir, a lo realmente existente.

De esta forma, según sugieren los resultados presentados, la crítica de la realidad también puede reforzar posturas conservadoras, en favor del statu quo que contribuyen a una morfostasis social. De hecho, en la crítica de personas ordinarias, lejanas a las posiciones de expertos e intelectuales, la tendencia apunta a la justificación de ciertos mecanismos que reproducen legítimamente desigualdades sociales. De esta forma -retornando al primer epígrafe de este trabajo-, el llamado de Marx hacia una crítica de la tierra pierde potencia, en tanto la crítica ordinaria principalmente se ocupa de reproducir sus propias condiciones de producción. La doble verdad propuesta por Bourdieu (1999) -ahora invocando el segundo epígrafe- ya advertía el problema: las visiones parciales de los sujetos en el espacio social recluyen su crítica al juego en que se ven inmersos. Por lo mismo, es excepcional e improbable el ejercicio de objetivación de la realidad social por parte de sujetos que se ven forzados a jugar según las reglas ya dispuestas.

Un problema que queda abierto se refiere a la dificultad, ya identificada por Bourdieu, de articular teóricamente la interpretación subjetiva de los jugadores con la objetiva de sus posiciones y tomas de posición. Por un lado, visto desde fuera, parece contraintuitivo que jugadores de clases desprivilegiadas sostengan principios que justifican su posición dominada. Por otro lado, en la interpretación de estos jugadores el problema reside en que algunos se saltan las reglas para generar desigualdades legítimas, sin percibir que muchas veces son estas reglas las que los sitúan en posiciones desaventajadas en el espacio social. La división entre vencedores y vencidos que impera en el marco de la igualdad de oportunidades tiende a culpar a los últimos de su derrota, pese a que, en última instancia, no es viable una verdadera igualdad de oportunidades donde cada uno es responsable de su éxito o fracaso (Dubet, 2013). Para Bourdieu la articulación entre esta interpretación subjetiva y objetiva se 
puede comprender mediante el habitus que, en la medida que incorpora las estructuras sociales de un contexto particular, tiende a reproducirlo sin necesidad de una coerción activa o un consentimiento consciente.

El presente estudio provee algunas luces sobre este problema, especialmente al identificar una relación entre la reflexividad y la crítica radical enunciada por algunos jugadores. Si la crítica ordinaria remite principalmente a la reproducción de una realidad social con múltiples desigualdades, cabe problematizar la excepcional emergencia de las críticas que van en sentido contrario y se asocia con procesos morfogenéticos. Los resultados sugieren que la reflexividad puede operar como parte del contra-adiestramiento que, según Bourdieu, permite transformar el habitus y su correspondiente tendencia a reproducir el contexto en el que fue producido. Por lo demás, aquello no implica homologar la reflexividad a una toma de conciencia que permita abruptamente superar la doble verdad, sino darle un lugar a la reflexividad dentro de un proceso de incorporación de estructuras sociales distintas a las existentes. La reflexividad, como conversación interna que también se manifiesta y potencia en la interacción grupal, es necesaria -aunque seguramente insuficiente por sí misma- para dar forma a disposiciones tendientes a cambiar la realidad social. 


\section{Bibliografía}

Adorno, T. W., \& Horkheimer, M. (2007). Dialéctica de la Ilustración. Madrid: Akal Ediciones.

Althusser, L. (1988). Ideología y aparatos ideológicos de estado: Freud y Lacan. Nueva Visión.

Anderson, P. (1981). Consideraciones sobre el marxismo occidental. México, D.F.: Siglo XXI Editores Mexico.

Antes, T. A. (1996). Kinesics: The Value of Gesture In Language and in the Language Classroom. Foreign Language Annals, 29(3), 439-448. https://doi.org/10.1111/j.1944-9720.1996.tb01255.x

Araujo, K. (2015). Las experiencias sociales y la creencia en la legitimidad. En M. Castillo \& Maldonado, Claudia, Desigualdades. Tolerancia, legitimación y conflicto en las sociedades latinoamericanas (pp. 69-94). Santiago de Chile: RIL.

Araujo, K. (2016). Desigualdades interaccionales e irritaciones relacionales: Sobre la contenciosa recomposición del lazo social en la sociedad chilena (Documento de Trabajo COES No. 3). Santiago de Chile.

Araujo, K., \& Martuccelli, D. (2011). La inconsistencia posicional: un nuevo concepto sobre la estratificación social. Recuperado a partir de http://repositorio.cepal.org//handle/11362/11453

Araujo, K., \& Martuccelli, D. (2012). Desafíos comunes. Retrato de la sociedad chilena y sus individuos (Vol. I). Santiago de Chile: Lom Ediciones.

Araujo, K., \& Martuccelli, D. (2014). Beyond institutional individualism: Agentic individualism and the individuation process in Chilean society. Current Sociology, 62(1), 24-40. https://doi.org/10.1177/0011392113512496 
Archer, M. S. (1996). Culture and Agency: The Place of Culture in Social Theory. Cambridge; New York: Cambridge University Press.

Archer, M. S. (2007). Making our Way through the World: Human Reflexivity and Social Mobility. Cambridge: Cambridge University Press.

Archer, M. S. (Ed.). (2010). Conversations About Reflexivity. Abingdon; New York: Routledge.

Archer, M. S. (2012). The Reflexive Imperative in Late Modernity. New York: Cambridge University Press.

Archer, M. S. (Ed.). (2013a). Social Morphogenesis. Dordrecht: Springer.

Archer, M. S. (2013b). Teoría social realista: el enfoque morfogenético. Santiago de Chile: Ediciones Universidad Alberto Hurtado.

Archer, M. S. (Ed.). (2014). Late Modernity: Trajectories towards Morphogenic Society. Cham; New York: Springer.

Arendt, H. (2006). Los orígenes del totalitarismo. Madrid: Alianza.

Austin, J. L. (1975). How to Do Things with Words. Cambridge, Mass.: Harvard University Press.

Barozet, E. (2006). El valor histórico del pituto: Clase media, integración y diferenciación social en Chile. Revista de Sociología, 20, 69-96.

Barozet, E., \& Espinoza, V. (2012). Que sont les classes sociales devenues? Stratification, inégalités et mobilité sociale au Chili. Cahiers des Amériques latines, 2011/3(68), 69-88. https://doi.org/10.4000/cal.89

Barozet, E., \& Fierro, J. (2011). Clase media en Chile, 1990-2011. Algunas implicancias sociales y políticas. Serie de Estudios Fundación Konrad Adenauer, $n^{\circ} 4$. 
Barozet, E., \& Mac-Clure, Ó. (2014). Nombrar y Clasificar: Aproximación a una Epistemología de las Clases Sociales. Cinta de moebio, 51, 197-215.

Barozet, E., \& Mac-Clure, Ó. (2015). Tolerancia a la desigualdad y justicia social. Una agenda teórica de investigación. En M. Castillo \& Maldonado, Claudia, Desigualdades. Tolerancia, legitimación y conflicto en las sociedades latinoamericanas (pp. 151-182). Santiago de Chile: RIL.

Basaure, M. (2011). In the epicenter of politics: Axel Honneth's theory of the struggles for recognition and Luc Boltanski and Laurent Thévenot's moral and political sociology. European Journal of Social Theory, 14(3), 263-281. https://doi.org/10.1177/1368431011412345

Basaure, M. (2014). Teoría crítica para tiempos de oscuridad. En torno a la propuesta de Robin Celikates. Persona y Sociedad, XXVIII(1).

Becker, H. S. (2009). Outsiders: Hacia una sociología de la desviación. Buenos Aires: Siglo XXI.

Bellei, C., Cabalin, C., \& Orellana, V. (2014). The 2011 Chilean student movement against neoliberal educational policies. Studies in Higher Education, 39(3), 426-440. https://doi.org/10.1080/03075079.2014.896179

Berger, P., \& Luckmann, T. (1996). La Construcción Social de La Realidad. Buenos Aires: Amorrortu Editores.

Bihr, A., \& Pfefferkorn, R. (2008). Le système des inégalités. Paris: Editions La Découverte. Birdwhistell, R. L. (1970). Kinesics and Context: Essays on Body Motion Communication. Philadelphia: University of Pennsylvania Press.

Boltanski, L. (1971). Les usages sociaux du corps. Annales. Histoire, Sciences Sociales, 26(1), 205-233. https://doi.org/10.3406/ahess.1971.422470 
Boltanski, L. (2011). On Critique: A Sociology of Emancipation. Cambridge, UK; Malden, MA: Polity.

Boltanski, L. (2012). Sociología y Crítica Social. Ciclo de Conferencias en la UDP. Santiago de Chile: Ediciones UDP.

Boltanski, L., \& Chiapello, E. (2002). El nuevo espíritu del capitalismo. Madrid: Akal.

Boltanski, L., \& Chiapello, E. (2007). The New Spirit of Capitalism. London; New York: Verso.

Boltanski, L., \& Thévenot, L. (1983). Finding one's way in social space: a study based on games. Social Science Information Sur Les Sciences Sociales, 22, 631-680. https://doi.org/10.1177/053901883022004003

Boltanski, L., \& Thévenot, L. (1999). The Sociology of Critical Capacity. European Journal of Social Theory, 2(3), 359-377. https://doi.org/10.1177/136843199002003010

Boltanski, L., \& Thévenot, L. (2006). On Justification: Economies of Worth. Princeton: Princeton University Press.

Bourdieu, P. (1991). Language and Symbolic Power. Cambridge: Polity Press.

Bourdieu, P. (1999). Meditaciones pascalianas. Barcelona: Anagrama.

Bourdieu, P. (2007). El sentido práctico. Buenos Aires: Siglo XXI.

Bourdieu, P. (2012). Bosquejo de una teoría de la práctica. Buenos Aires: Prometeo.

Brunkhorst, H. (2014). Kritik und kritische Theorie. Nomos.

Carvacho, H., Zick, A., Haye, A., González, R., Manzi, J., Kocik, C., \& Bertl, M. (2013). On the relation between social class and prejudice: The roles of education, income, and ideological attitudes. European Journal of Social Psychology, 43(4), 272-285. https://doi.org/10.1002/ejsp.1961 
Castillo, J. C. (2009). ¿Cuál es la brecha salarial justa? Opinión pública y legitimación de la desigualdad en Chile. Estudios Públicos, $n^{\circ} 113$.

Castillo, J. C. (2011). Legitimacy of Inequality in a Highly Unequal Context: Evidence from the Chilean Case. Social Justice Research, 24(4), 314-340. https://doi.org/10.1007/s11211-011-0144-5

Castillo, J. C. (2012a). Is Inequality Becoming Just? Changes in Public Opinion about Economic Distribution in Chile. Bulletin of Latin American Research, 31(1), 1-18. https://doi.org/10.1111/j.1470-9856.2011.00605.x

Castillo, J. C. (2012b). La legitimidad de las desigualdades salariales. Una aproximación multidimensional. Revista internacional de sociología, 70(3), 533-560.

Castillo, J. C., Miranda, D., \& Carrasco, D. (2012). Percepción de Desigualdad Económica en Chile: Medición, Diferencias y Determinantes. Psykhe (Santiago), 21(1), 99-114. https://doi.org/10.4067/S0718-22282012000100007

Castillo, M. (2011). El centro de la disputa: las clases medias y la política de la desigualdad en Chile. En M. Castillo, M. Bastías, \& A. Durand (Eds.), Desigualdad, legitimación y conflicto. Dimensiones políticas y culturales de la desigualdad en América Latina. Santiago de Chile: Ediciones Universidad Alberto Hurtado.

Coleman, J. (1990). Foundations of Social Theory. Cambridge, MA: Belknap Press.

Dubet, F. (2013). Repensar la justicia social. Buenos Aires: Siglo XXI.

Durkheim, E. (1989). El suicidio. Madrid: Akal Ediciones.

Erikson, R., \& Goldthorpe, J. H. (1993). The constant flux: a study of class mobility in industrial societies. Oxford: Clarendon Press. 
Forbes-Pitt, K. (2013). Self-Organization: What Is It, What Isn't It and What's It Got to Do with Morphogenesis? En M. S. Archer (Ed.), Social Morphogenesis. Dordrecht: Springer.

Forst, R. (2014). Justification and Critique: Towards a Critical Theory of Politics. Cambridge; Malden: Polity Press.

Garretón, M. A. (2003). Incomplete Democracy: Political Democratization in Chile and Latin America. Chapel Hill: The University of North Carolina Press.

Garretón, M. A. (2005). Social sciences and society in Chile: institutionalization, breakdown and rebirth. Social Science Information, 44(2-3), 359-409. https://doi.org/10.1177/0539018405053292

Garretón, M. A. (2012). Neoliberalismo corregido y progresismo limitado. Santiago de Chile: CLACSO y Universidad Arcis.

Garretón, M. A., \& Cumsille, G. (2002). Las percepciones de la desigualdad en Chile. Proposiciones, 34 .

Ghouri, N. (2009, junio 1). The great carbon credit con: Why are we paying the Third World to poison its environment? Mail Online. Recuperado a partir de http://www.dailymail.co.uk/home/moslive/article-1188937/The-great-carbon-crediteco-companies-causing-pollution.html

Giddens, A. (1995). La constitución de la sociedad. Bases para la teoría de la estructuración. Buenos Aires: Amorrortu Editores.

Godelier, M. (1976). Funcionalismo, estructuralismo y marxismo. Barcelona: Anagrama.

Goffman, E. (1966). Behavior in Public Places. New York, NY: The Free Press.

Goffman, E. (1997). La presentación de la persona en la vida cotidiana. Buenos Aires: Amorrortu Editores. 
Goffman, E. (2001). Internados: ensayos sobre la situación social de los enfermos mentales. Amorrortu Editores.

Guerrero, J. C., \& Ramírez, H. (2011). La justicia, la crítica y la justificación. Un análisis desde la perspectiva de la sociología pragmática. Revista Colombiana de Sociología, $34(1), 41-73$.

Guzmán, V., Barozet, E., \& Méndez, M. L. (2017). Legitimación y crítica a la desigualdad: una aproximación pragmática. Convergencia: revista de ciencias sociales, 72. Recuperado a partir de https://ddd.uab.cat/record/168581

Habermas, J. (2010). Teoría de la acción comunicativa. Madrid: Editorial Trotta.

Hall, J., Bernieri, F., \& Carney, D. (2008). Nonverbal behavior and interpersonal sensitivity. En R. Rosenthal \& J. Harrigan, New Handbook of Methods in Nonverbal Behavior Research (pp. 137-198). Oxford: Oxford University Press.

Harrigan, J. (2008). Proxemics, kinesics and gaze. En R. Rosenthal \& J. Harrigan, New Handbook of Methods in Nonverbal Behavior Research (pp. 137-198). Oxford University Press.

Harrigan, J., \& Rosenthal, R. (2008). New Handbook of Methods in Nonverbal Behavior Research. Oxford University Press.

Hernández, R., Fernández, C., \& Baptista, P. (2010). Metodología de la investigación. Quinta edición. México D.F.: McGraw-Hill Interamericana Editores.

Honneth, A. (1996). The Struggle for Recognition: Moral Grammar of Social Conflicts. Cambridge, UK; Oxford; Cambridge, MA: Polity Press.

Ibáñez, S. (2013). Legitimación de las desigualdades de ingreso: ¿Principios o Ideología? (Avance de Investigación en curso. Grupo de trabajo n8. Desigualdad, vulnerabilidad y exclusión social). 
Jaksic, I. (2013). Rebeldes académicos: La filosofía chilena desde la Independencia hasta 1989. Ediciones UDP.

Keucheyan, R. (2013). Left Hemisphere: Mapping Contemporary Theory. (G. Elliott, Trad.). London; Brooklyn, NY: Verso.

Koselleck, R. (1998). Critique and Crises: Enlightenment and the Pathogenesis of Modern Society. Cambridge, Mass.: The MIT Press.

Koselleck, R. (2004). Futures Past: On the Semantics of Historical Time. New York: Columbia University Press.

Latour, B. (1993). The Pasteurization of France. Cambridge, MA; London: Harvard University Press.

Lechner, N. (2007). Obras escogidas (Vol. II). Santiago de Chile: Lom Ediciones.

Liebig, S. (2001). Lessons from Philosophy? Interdisciplinary Justice Research and Two Classes of Justice Judgments. Social Justice Research, 14(3), 265-287. https://doi.org/10.1023/A:1014367907348

López, R., Figueroa, E., \& Gutiérrez, P. (2013). La “parte del león”: Nuevas estimaciones de la participación de los súper ricos en el ingreso de Chile (Serie de Documentos de trabajo). Santiago de Chile: Facultad de Economía y Negocios Universidad de Chile.

Mac-Clure, O., \& Barozet, E. (2016). Judgments on (in)justice in a mature neoliberal regime: Results of an empirical game-based research. Current Sociology, 64(3), 335-352. https://doi.org/10.1177/0011392115590489

Mac-Clure, O., Barozet, E., \& Moya, C. (2015). Juicios de las clases medias sobre la élite económica: ¿Crítica a las desigualdades en Chile? Polis, 42. 
Martinic, S. (2006). El estudio de las representaciones y el Análisis Estructural de Discurso. En M. Canales, Metodologías de la investigación social (pp. 299-319). Santiago de Chile: Lom Ediciones.

Marx, K. (1982). En torno a la crítica de la filosofía del derecho de Hegel. En Escritos de juventud. México D.F.: Fondo de Cultura Económica.

Marx, K. (2003). El dieciocho Brumario de Luis Bonaparte. Madrid: Alianza.

Micco, S. (2014). La política sin los intelectuales. De la deserción al reencuentro. Santiago de Chile: Universitaria.

Miller, D. (1999). Principles of Social Justice. Cambridge, MA; London: Harvard University Press.

Moulian, T. (2002). Chile actual: anatomía de un mito. Santiago de Chile: Lom Ediciones.

Öztürk, Ş. (2011). Pierre Bourdieu's Theory Of Social Action. Sosyal Bilimler Dergisi, 1(15), 249-264.

Parsons, T. (1968). La estructura de la acción social. Estudio de teoría social con referencia a un grupo de recientes escritores europeos (Vols. 1-2). Madrid: Guadarrama.

Parsons, T. (2012). The Social System. New Orleans, LA: Quid Pro, LLC.

Pérez-Ahumada, P. (2014). Class consciousness in a mature neoliberal society: Evidence from Chile. Research in Social Stratification and Mobility, 38, 57-75. https://doi.org/10.1016/j.rssm.2014.06.002

PNUD. (1998). Informe Desarrollo Humano en Chile. Año 1998. Las paradojas de la Modernización. PNUD.

Porpora, D. V. (2013). Morphogenesis and Social Change. En M. S. Archer, Social Morphogenesis (pp. 25-38). Dordrecht: Springer.

Poulantzas, N. (1979). Las clases sociales en el capitalismo actual. México D.F.: Siglo XXI. 
Poyatos, F. (2002). Nonverbal Communication Across Disciplines: Paralanguage, kinesics, silence, personal and environmental interaction. Amsterdam; Philadelphia, PA: John Benjamins Publishing.

Proyecto Desigualdades. (2013). Méthode de recherche appliquée dans le cadre du projet Fondecyt FONDECYT Regular $N^{\circ} 1130800$ "Dujugement critique micro a la critique systématique: pour une sociologie de la critique au Chili” (2013-2015) (Documento de trabajo). Santiago de Chile.

Puga, I. (2011). Lo justo y lo posible: desigualdad, legitimidad e ideología en Chile. En M. Castillo, M. Bastías, \& A. Durand (Eds.), Desigualdad, legitimación y conflicto. Dimensiones políticas y culturales de la desigualdad en América Latina. Santiago de Chile: Ediciones Universidad Alberto Hurtado.

Rojas, J. (2012). Sociedad bloqueada. Movimiento estudiantil, desigualdad y despertar de la sociedad chilena. Santiago de Chile: Ril Editores.

Ruiz E., C. (2013a). Conflicto social en el "neoliberalismo avanzado”. Análisis de clase de la revuelta estudiantil en Chile. Buenos Aires: CLACSO.

Ruiz E., C. (2013b). Estado, alianzas sociales y modelos de desarrollo en América Latina hoy: Brasil, Argentina y Chile (Tesis para optar al grado de Doctor en Estudios Latinoamericanos). Universidad de Chile, Santiago de Chile.

Ruiz E., C., \& Boccardo, G. (2011). Panorama actual de la estructura social chilena. (en la perspectiva de las transformaciones de la historia inmediata) (Documento de trabajo). Santiago de Chile: Centro de Investigación de la Estructura Social.

Ruiz E., C., \& Boccardo, G. (2014). Los chilenos bajo el neoliberalismo. Clases y conflicto social. Santiago de Chile: Nodo XXI y El Desconcierto. 
Schwalbe, M., Godwin, S., Holden, D., Schrock, D., Thompson, S., \& Wolkomir, M. (2000). Generic Processes in the Reproduction of Inequality: An Interactionist Analysis. Social Forces, 79(2), 419-452. https://doi.org/10.2307/2675505

Thibaut, J. W., \& Walker, L. (1975). Procedural Justice: A Psychological Analysis. L. Erlbaum Associates.

Tilly, C. (2000). La desigualdad persistente. Buenos Aires: Manantial.

Tyler, T. R., \& Blader, S. L. (2003). The Group Engagement Model: Procedural Justice, Social Identity, and Cooperative Behavior. Personality and Social Psychology Review, 7(4), 349-361. https://doi.org/10.1207/S15327957PSPR0704_07

Van den Bos, K. (1999). What are we talking about when we talk about no-voice procedures? On the psychology of the fair outcome effect. Journal of Experimental social psychology, 35(6), 560-577.

Velasco, J. P. (2013). La competencia nacional. Tolerancia a la desigualdad persistente en los Sectores Medios del Chile contemporáneo (Memoria para optar al título de Sociólogo). Universidad de Chile.

Weber, M. (2008). Economía y sociedad. Esbozo de sociología comprensiva. México, D.F.: Fondo de Cultura Económica.

Wright, E. O., \& Shin, K.-Y. (1988). Temporality and Class Analysis: A Comparative Study of the Effects of Class Trajectory and Class Structure on Class Consciousness in Sweden and the United States. Sociological Theory, 6(1), 58-84. https://doi.org/10.2307/201914

Zelditch, M., Berger, J., Anderson, B., \& Cohen, B. (1972). Structural Aspects of Distributive Justice: A Status-Value Formulation. En J. Berger, M. Zelditch, \& B. Anderson, Sociological Theories in Progress (Vol. II). Boston: Houghton Mifflin. 